\author{
UNIVERSIDADE DE SÃO PAULO \\ FACULDADE DE CIÊNCIAS FARMACÊUTICAS \\ PROGRAMA DE PÓS-GRADUAÇÃO EM FÁRMACO E MEDICAMENTOS \\ ÁREA DE PRODUÇÃO E CONTROLE FARMACÊUTICOS
}

\title{
DETERMINAÇÃO QUANTITATIVA DE GEMIFLOXACINO POR CROMATOGRAFIA LÍQUIDA DE ALTA EFICIÊNCIA E ELETROFORESE CAPILAR
}

\section{VANESSA FRANCO TAVARES}

\author{
Dissertação para o Grau de \\ MESTRE \\ Orientadora \\ Profa. Dra. Maria Inês Rocha Miritello Santoro
}

São Paulo

2010 


\author{
UNIVERSIDADE DE SÃO PAULO \\ FACULDADE DE CIÊNCIAS FARMACÊUTICAS \\ PROGRAMA DE PÓS-GRADUAÇÃO EM FÁRMACO E MEDICAMENTOS \\ ÁREA DE PRODUÇÃO E CONTROLE FARMACÊUTICOS
}

\title{
DETERMINAÇÃO QUANTITATIVA DE GEMIFLOXACINO POR CROMATOGRAFIA LÍQUIDA DE ALTA EFICIÊNCIA E ELETROFORESE CAPILAR
}

\section{VANESSA FRANCO TAVARES}

\author{
Dissertação para o Grau de \\ MESTRE
}

Orientadora

Profa. Dra. Maria Inês Rocha Miritello Santoro

São Paulo

2010 
Ficha Catalográfica

Elaborada pela Divisțo de Biblioteca c

Documentação do Conjunto das Quimicas da USP

\begin{tabular}{|c|c|}
\hline \multirow[t]{4}{*}{$\mathrm{T} 231 \mathrm{~d}$} & $\begin{array}{l}\text { Tavares, Vanessa Franco } \\
\text { Determinaçăo quantitativa de gemifloxacine por cromatografia } \\
\text { liquida de alta eficiéncia e eletroforese capilar / Vanessa Franco } \\
\text { Tavares. - Sào Paulo, } 2010 \text {. } \\
\text { I16p. }\end{array}$ \\
\hline & $\begin{array}{l}\text { Dissertação (mestrado) - Faculdade de Ciências Farmacêuticas } \\
\text { da Universidade de Sào Paulo. Departamento de Farmácia. } \\
\text { Orientador: Santoro. Maria Inés Rocha Miritello }\end{array}$ \\
\hline & $\begin{array}{l}\text { 1. Medicamento : Controle de qualidade } 2 \text {. Eletroforese } \\
\text { capilar: Análise quimica : Farmacologia 3. Cromatografia om } \\
\text { liquido de alta eficiência : Análise quimica : Farmacologia L. } \mathrm{T} \text {. } \\
\text { II. Santoro, Maria lnés Rocha Miritello, orientador. }\end{array}$ \\
\hline & 615.19015 \\
\hline
\end{tabular}




\section{Vanessa Franco Tavares}

Determinação quantitativa de gemifloxacino por cromatografia líquida de alta eficiência e eletroforese capilar

Comissão julgadora

da

Dissertação para o Grau de

MESTRE

Profa. Titular Dra. Maria Inês Rocha Miritello Santoro Orientador/Presidente

1ํㅡㄹ Examinador

2ํㅡㄹ Examinador

São Paulo, de de 2010 
"Sentir primeiro, pensar depois Perdoar primeiro, julgar depois Amar primeiro, educar depois Esquecer primeiro, aprender depois

Libertar primeiro, ensinar depois Alimentar primeiro, cantar depois

Possuir primeiro, contemplar depois Agir primeiro, julgar depois

Navegar primeiro, aportar depois Viver primeiro, morrer depois" (Mário Quintana) 
Aे Deus, pelo amor, pela minha vida, pelo ar em meus pulmões, por me manter sempre em pé, por iluminar meus caminhos, e a fé nEle que não me deixa cair e sempre me faz persistir. 
Aos meus pais, Amaury e Roseli Por serem meu refúgio, meu chão, a coluna mais forte. Pelo amor, (muita) paciência, incentivo e dedicação, sempre me levando para frente. Obrigada por nunca perderem a fé em mim!

Aos meus irmãos, Paulo e Bruna por darem mais sentido a minha vida. 
À Professora Maria Inês R. M. Santoro Obrigada pela preciosa oportunidade e orientação. Obrigada pela chance de crescimento profissionale principalmente pessoal. É muito grande minha admiração. 


\section{AGRADECIMENTOS}

À Profa. Érika Rosa Maria Kedor-Hackmann pelo espaço, pelos conselhos e carinho.

À Dra. Daniela Patto, uma pessoa que se tornou essencial, por todo apoio, que entre muitas risadas e desabafos fez, de uma grande mudança, ficar mais fácil para mim. Obrigada pela amizade.

À Mariana, Cibele, Carol, Túlia, Helen, Vivian e Daniele pela amizade, carinho, conselhos, muitas risadas, pela troca de experiências e por todos bons momentos.

Ao Aché Laboratórios Farmacêuticos S.A. pela doação das amostras.

Aos colegas do laboratório de Controle Físico-Químico de Qualidade de Medicamentos e Cosméticos pela amizade, troca de informações e colaboração.

Às funcionárias Iria e Raquel pela amizade, carinho e apoio.

Aos Professores Anil K. Singh e Maria Segunda Aurora Prado pela colaboração no desenvolvimento do projeto.

Ao Programa de pós- graduação em Fármaco e Medicamento, todos os professores e funcionários pela grande oportunidade.

À Coordenação de Aperfeiçoamento de Pessoal de Ensino Superior (CAPES) pelo apoio financeiro.

À todos que colaboraram de forma indireta e direta no desenvolvimento desta dissertação. 
RESUMO 1

ABSTRACT

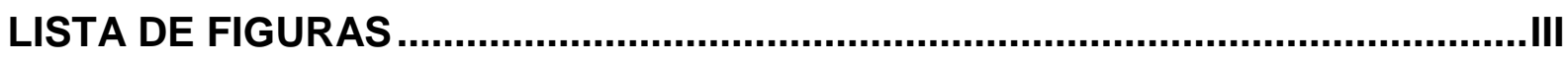

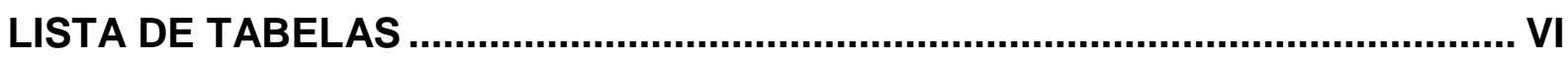

LISTA DE ABREVIATURAS E SÍMBOLOS ....................................................... VII

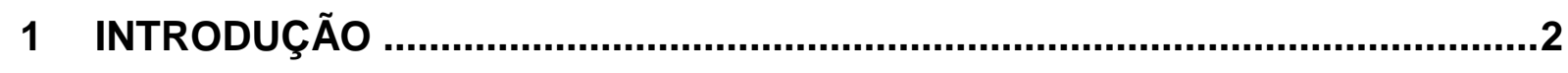

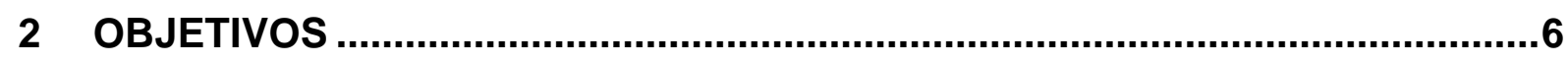

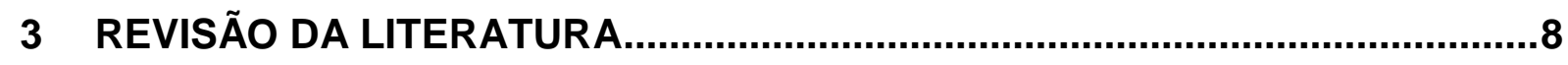

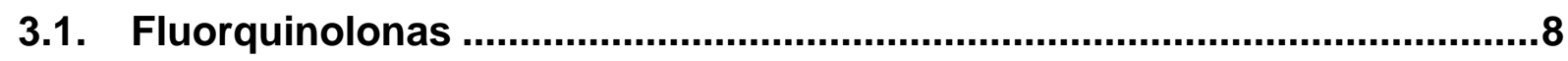

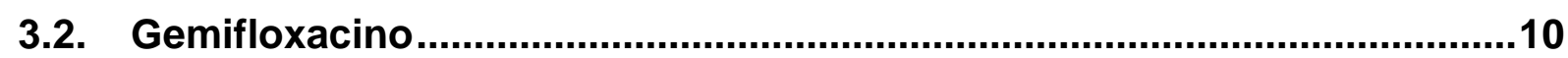

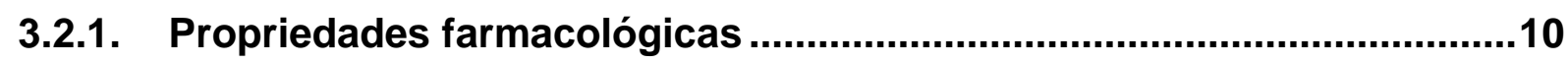

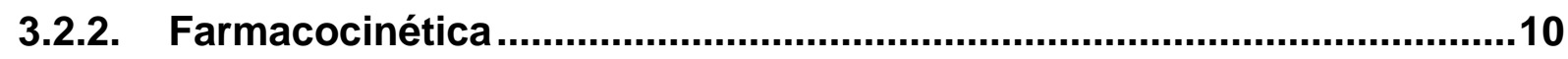

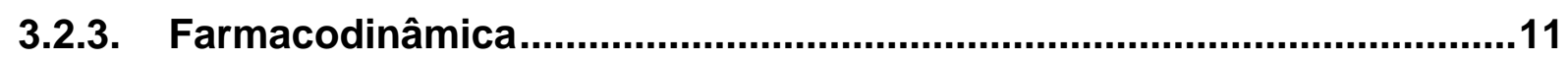

3.2.4. Propriedades físico-químicas ...........................................................11

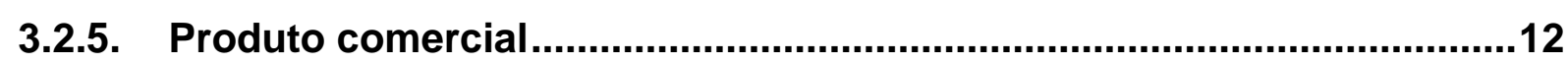

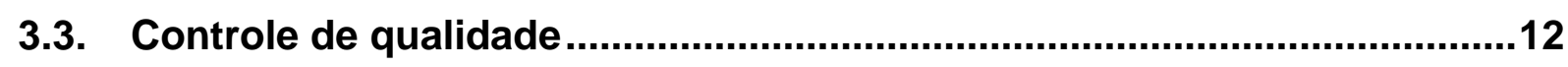

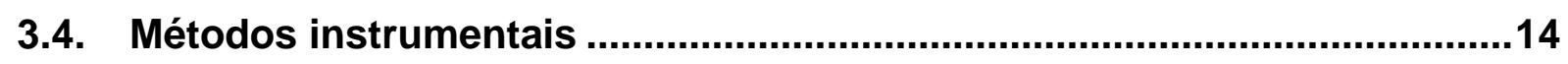

3.4.1. Cromatografia líquida de alta eficiência...............................................15

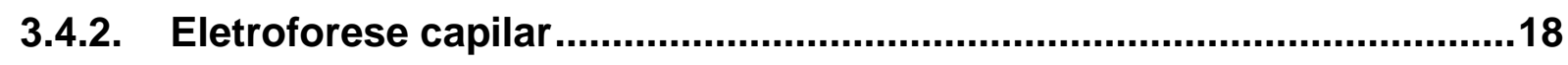

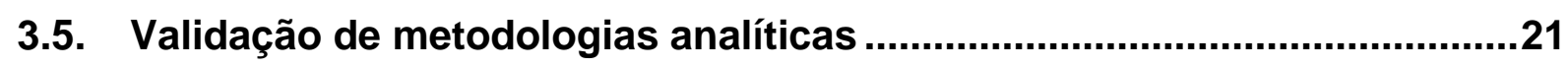

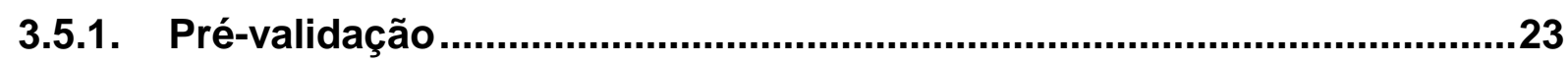

3.6. Revisão das metodologias publicadas para quinolonas .........................27

3.6.1. Cromatografia líquida de alta eficiência............................................27

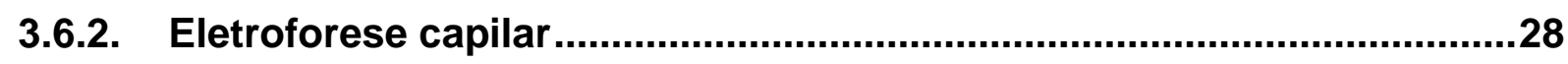


4 JUSTIFICATIVA

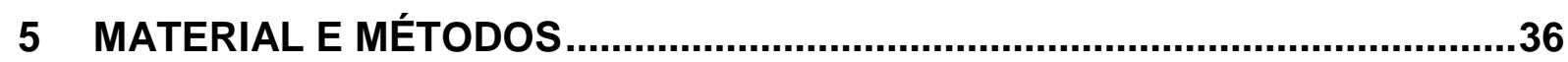

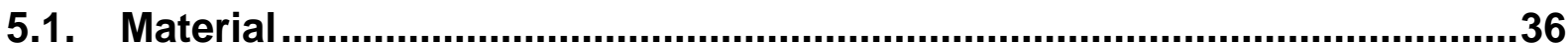

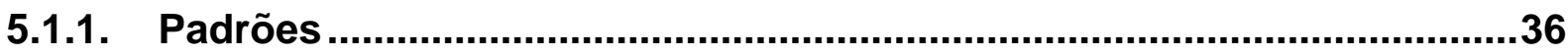

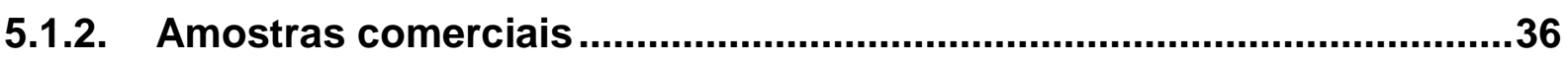

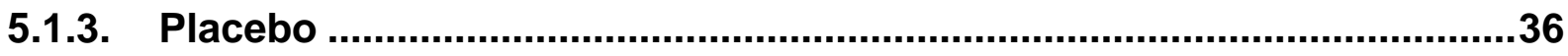

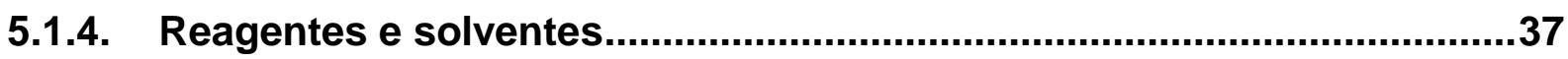

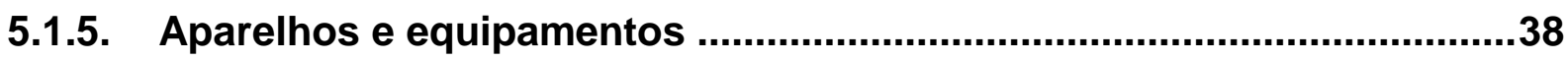

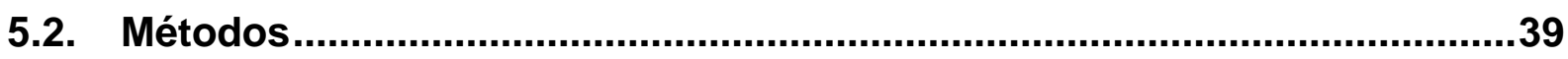

5.2.1. Determinação do comprimento de onda.................................................39

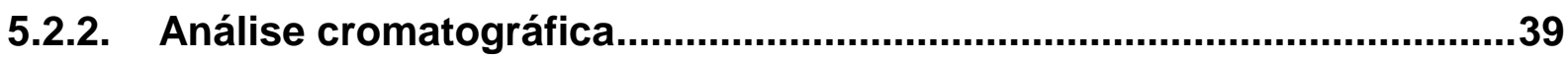

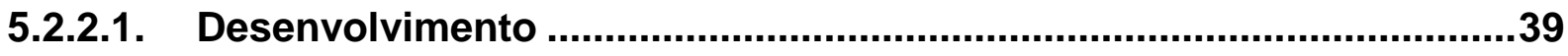

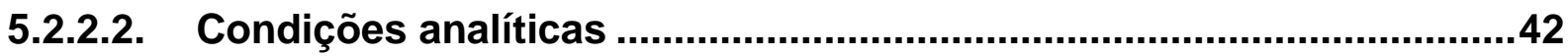

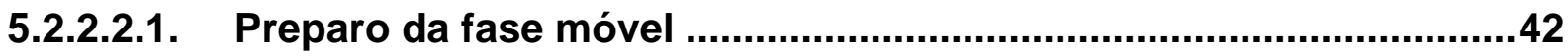

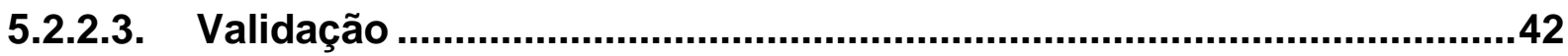

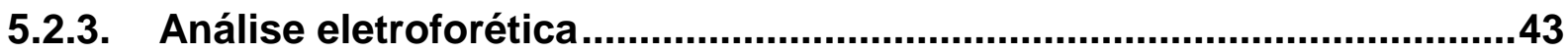

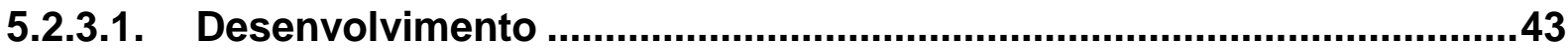

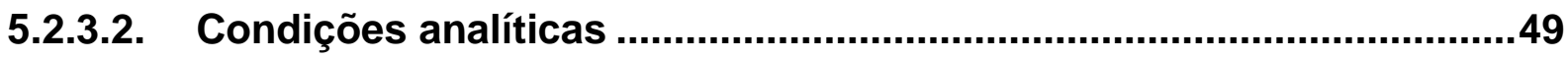

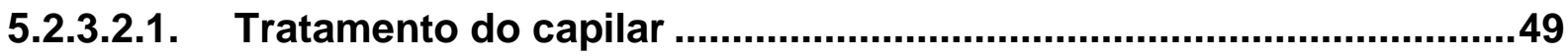

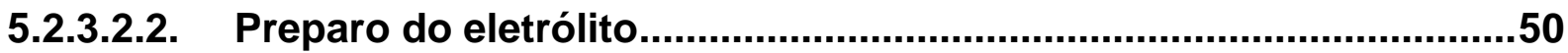

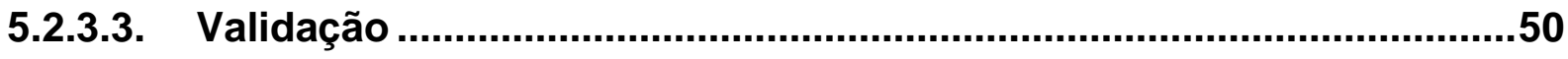

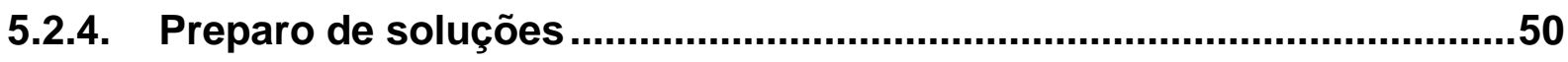

5.2.4.1. Solução padrão estoque de gemifloxacino .........................................51

5.2.4.2. Solução padrão estoque de metoprolol .............................................51

5.2.4.3. Preparo da solução estoque da amostra de gemifloxacino.................51

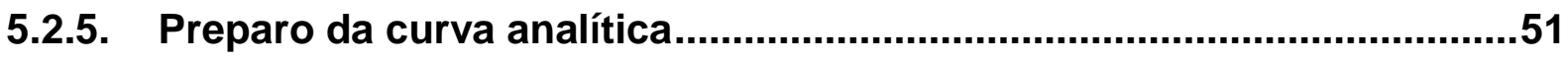




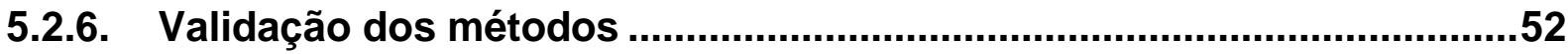

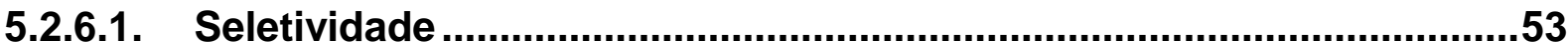

5.2.6.1.1. Pesquisa de interferentes no placebo .............................................53

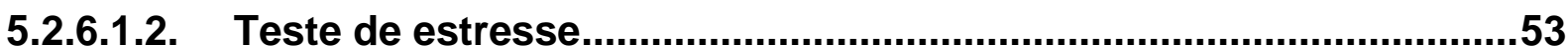

5.2.6.1.3. Hidrólise em meio neutro ..............................................................53

5.2.6.1.4. Hidrólise em meio oxidativo ..............................................................54

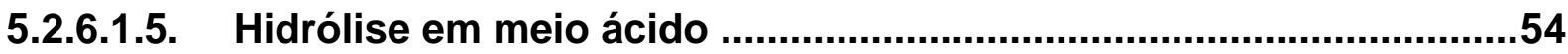

5.2.6.1.6. Hidrólise em meio alcalino ...........................................................55

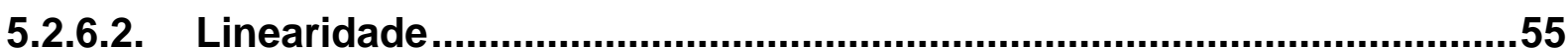

5.2.6.3. Limite de detecção (LD) e limite de quantificação (LQ)......................56

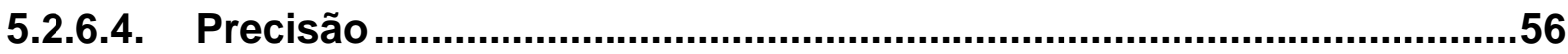

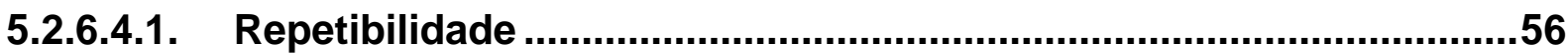

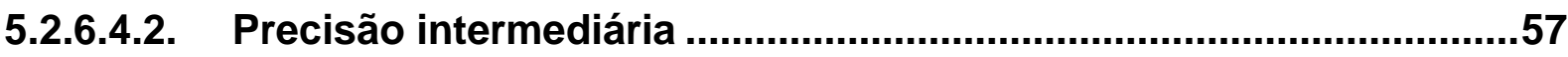

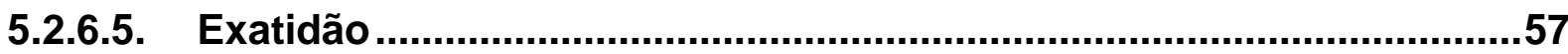

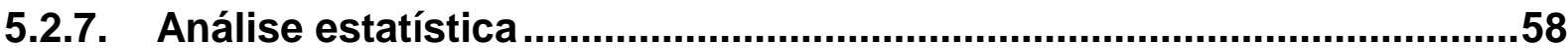

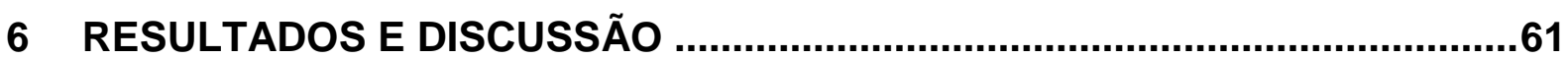

6.1. Gemifloxacino

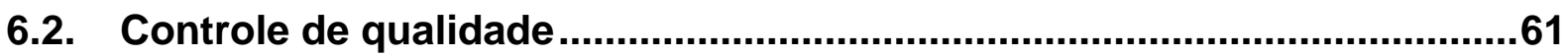

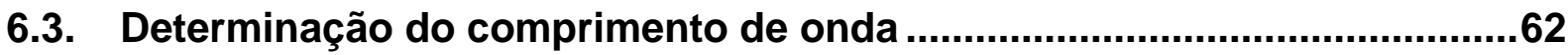

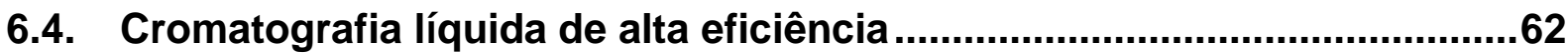

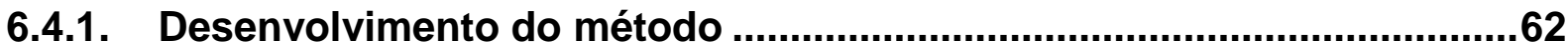

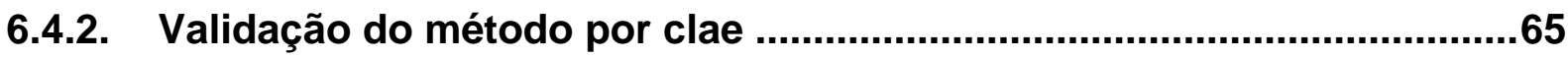

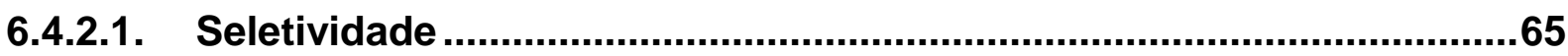

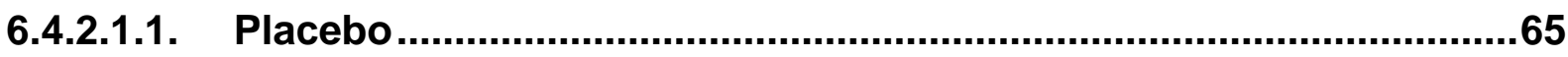

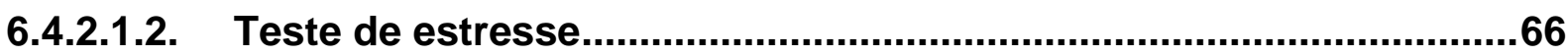

6.4.2.1.2.1. Hidrólise em meio neutro ..........................................................66 


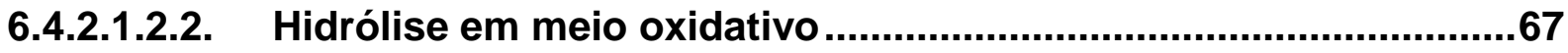

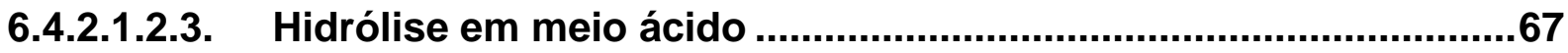

6.4.2.1.2.4. Hidrólise em meio básico ...........................................................68

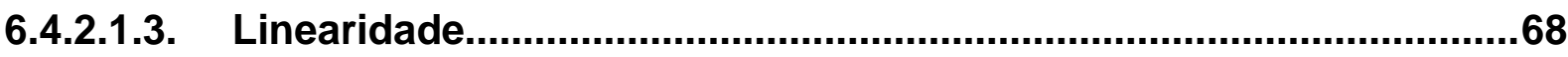

6.4.2.1.4. Limite de detecção (LD) e limite de quantificação (LQ) ....................70

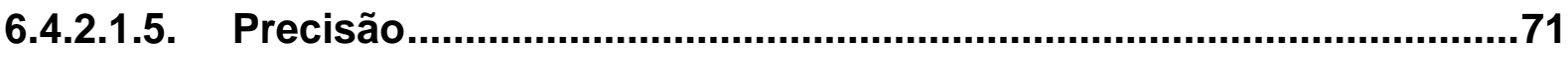

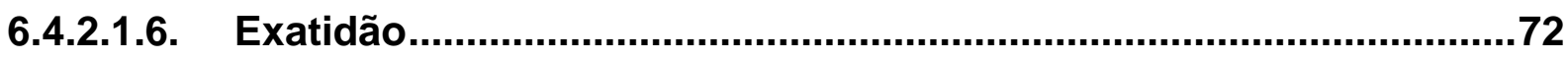

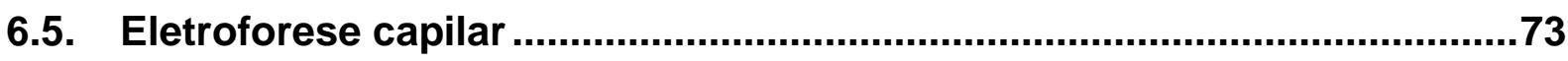

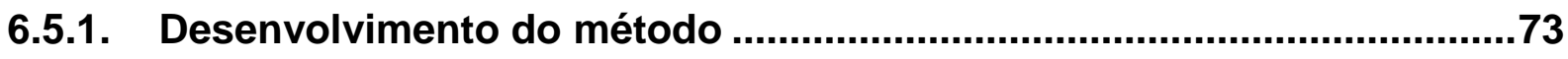

6.5.2. Validação do método por eletroforese capilar .........................................75

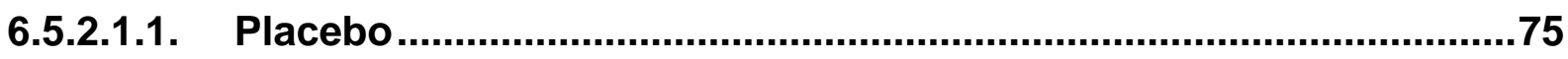

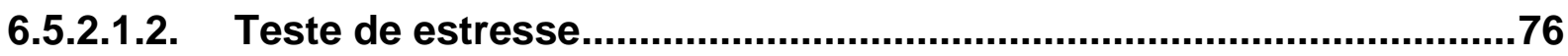

6.5.2.1.2.1. Hidrólise em meio neutro …….....................................................76

6.5.2.1.2.2. Hidrólise em meio oxidativo .............................................................77

6.5.2.1.2.3. Hidrólise em meio ácido ….........................................................77

6.5.2.1.2.4. Hidrólise em meio básico ............................................................78

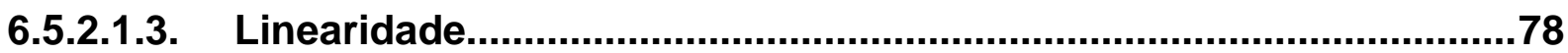

6.5.2.1.4. Limite de detecção e limite de quantificação ......................................80

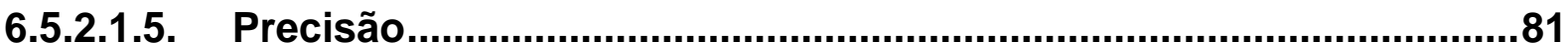

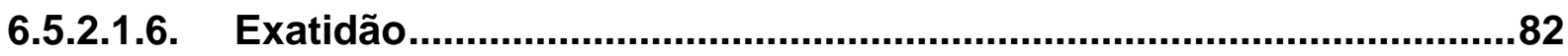

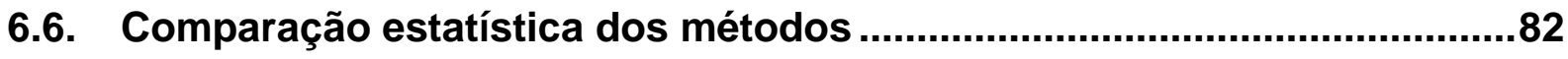

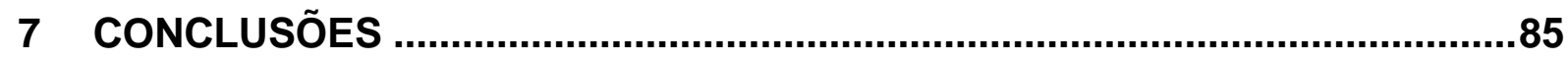

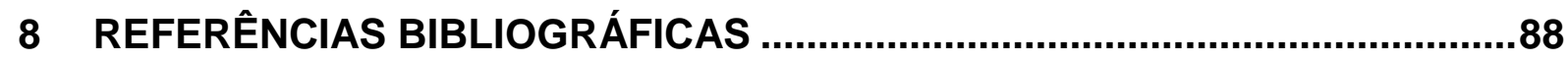

ANEXOS 


\section{RESUMO}

Gemifloxacino (GMFLX) é um agente fluorquinôlonico, antibacteriano recentemente desenvolvido que apresenta um amplo espectro de atividade. O objetivo deste estudo foi desenvolver e validar métodos seletivos e sensíveis para a determinação quantitativa de GMFLX em comprimidos revestidos por cromatografia líquida de alta eficiência (CLAE) e eletroforese capilar de zona (CZE). O método por CLAE foi realizado em uma coluna LiChrospher ${ }^{\circledR} 100 \mathrm{RP}-8 \mathrm{e}, 5 \mu \mathrm{m}(125 \times 4 \mathrm{~mm})$ e uma fase móvel composta por tetraidrofurano:água $(25: 75, \mathrm{v} / \mathrm{v})$ com $0.5 \%$ de trietilamina e pH ajustado para 3.0 com ácido ortofosfórico. O tempo de retenção do GMFLX foi de 2.3 min. O método mostrou boa linearidade $\left(r^{2} 0.9989\right)$ e precisão (RSD\% $\left.<0.89\right)$. A exatidão foi expressa em percentagem de recuperação ( $R \% \leq 101.3 \%)$. O método por CZE foi realizado utilizando $50 \mathrm{mmol} \mathrm{L}^{-1}$ de tampão tetraborato de sódio ( $\mathrm{pH} 8.6$ ). As amostras foram injetadas hidrodinâmicamente $(0.5 \mathrm{psi}, 5 \mathrm{~s})$ e o sistema eletroforético foi operado sob polaridade normal, em $+20 \mathrm{kV}$ e temperatura de $18^{\circ} \mathrm{C}$. $O$ capilar utilizado foi de sílica fundida de $40.2 \mathrm{~cm}$ de comprimento (30 cm efetivos) $\mathrm{x}$ $75 \mu \mathrm{m}$ (d.i.) $\times 375 \mu \mathrm{m}$ (d.e.). Esse método apresentou um tempo de migração de 2.55 min para o GMFLX e 1.66 min para o metoprolol (padrão interno). Os parâmetros avaliados apresentaram linearidade $\left(r^{2}\right.$ 0.9992), precisão (RSD\% < 4.2) e exatidão ( $R \% \leq 101.8 \%$ ). Tanto a CLAE quanto a CZE foram consideradas técnicas interessantes e eficientes para serem aplicadas no controle de qualidade em indústrias farmacêuticas.

Palavras-chave: Gemifloxacino, cromatografia líquida de alta eficiência, eletroforese capilar de zona, validação, formulações farmacêuticas 
Tavares, V.F. Quantitative determination of gemifloxacin mesylate in tablets by capillary zone electrophoresis and high performance liquid chromatography. Dissertação (mestrado). XX f., 2010.

\section{ABSTRACT}

Gemifloxacin (GMFLX) is a recently developed fluorquinolone antibacterial agent presenting a broad spectrum of activity. The aim of this study was to develop and validate selective and sensitive methods for quantitative determination of GMFLX in coated tablets by high performance liquid chromatography (HPLC) and capillary zone electrophoresis (CZE). The HPLC method was carried out on a LiChrospher ${ }^{\circledR} 100$ RP-8e, $5 \mu \mathrm{m}(125 \times 4 \mathrm{~mm})$ column with a mobile phase composed of tetrahydrofuranwater $(25: 75, \mathrm{v} / \mathrm{v})$ with $0.5 \%$ of triethylamine and $\mathrm{pH}$ adjusted to 3.0 with orthophosphoric acid. The retention time of GMFLX was $2.3 \mathrm{~min}$. The method showed good linearity $\left(r^{2} 0.9989\right)$ with good precision (RSD $\left.<0.89 \%\right)$. Accuracy was expressed as percentage recovery $(R \% \leq 101.3 \%)$. The CZE method was performed using $50 \mathrm{mmoL}^{-1}$ sodium tetraborate buffer $(\mathrm{pH}$ 8.6). Samples were injected hydrodynamicaly $(0.5 \mathrm{psi}, 5 \mathrm{~s})$ and the electrophoretic system was operated under normal polarity, at $+20 \mathrm{kV}$ and temperature of $18^{\circ} \mathrm{C}$. A fused-silica capillary $40.2 \mathrm{~cm}$ (30 cm effective length) $\times 75 \mu \mathrm{m}$ (i.d.) $\times 375 \mu \mathrm{m}$ (o.d.) was used. This method presented a migration time of $2.55 \mathrm{~min}$ for GMFLX and $1.66 \mathrm{~min}$ for metoprolol (internal standard). The evaluated parameters presented acceptable linearity $\left(r^{2}\right.$ 0.9992), precision (RSD < 4.2\%) and accuracy (R\% $101.8 \%)$. Both, HPLC and CZE method could be interesting and efficient techniques to be applied for quality control in pharmaceutical industries.

Keywords: gemifloxacin, high performance liquid chromatography, capillary zone electrophoresis, validation, pharmaceutical formulations 


\section{LISTA DE FIGURAS}

Figura 1 Estrutura química do mesilato de gemifloxacino

Página

Figura 2 Representação de um equipamento de CLAE

Figura 3 Representação da instrumentação da EC

Figura 4 Esquema da formação e do sentido do fluxo eletro-osmótico 18

Figura 5 Espectro de absorção de gemifloxacino na concentração de 20 $100.0 \mathrm{ng} \mathrm{mL}^{-1} \mathrm{em}$ água.

Figura 6 Cromatograma da solução de gemifloxacino $80,0 \mu \mathrm{g} \mathrm{mL}{ }^{-1}$; Condições: coluna LiChrospher 100 RP-8e $(5 \mu \mathrm{m}, 125 \times 4$ $\mathrm{mm}$ ), vazão: $1,0 \mathrm{~mL} \mathrm{~min}{ }^{-1}$, fase móvel: MeCN: TEA 0.5\%, $\mathrm{pH}$ 3,0 ajustado com ácido ortofosfórico (20:80 v/v); detecção UV de $280 \mathrm{~nm}$.

Figura 7 Cromatograma da solução de gemifloxacino $80.0 \mu \mathrm{g} \mathrm{mL}{ }^{-1}$. Condições: coluna LiChrospher 100 RP-8e $(5 \mu \mathrm{m}, 125 \times 4$ $\mathrm{mm}$ ); fase móvel MeCN: TEA 0.5\% pH 3.0 ajustado com ácido ortofosfórico (30:70 v/v); fluxo: $1.0 \mathrm{~mL} \mathrm{~min}^{-1}$; detecção UV de $280 \mathrm{~nm}$.

Figura 8 Cromatograma da solução de gemifloxacino $80,0 \mu \mathrm{gL}^{-1}$; Condições: coluna LiChrospher 100 RP-8e $(5 \mu \mathrm{m}, 125 \times 4$ $\mathrm{mm}$ ); fase móvel $\mathrm{MeOH}$ : TEA 0,5\% pH 3,0 ajustado com ácido ortofosfórico (20:80 v/v); fluxo: 1,0 $\mathrm{mL} \mathrm{min}^{-1}$; detecção UV de $280 \mathrm{~nm}$.

Figura 9 Cromatograma da solução de gemifloxacino $80,0 \mu \mathrm{g} \mathrm{mL}^{-1}$. Condições: coluna LiChrospher 100 RP-8e $(5 \mu \mathrm{m}, 125 \times 4$ $\mathrm{mm}$ ); fase móvel THF: TEA 0,5\% pH 3,0 ajustado com ácido ortofosfórico (25:75 v/v); fluxo: 1,0 mL min ${ }^{-1}$; detecção UV de $280 \mathrm{~nm}$.

Figura 10 Cromatograma da solução de placebo. Condições: coluna LiChrospher $100 \mathrm{RP}-8 \mathrm{e}(5 \mu \mathrm{m}, 125 \times 4 \mathrm{~mm})$, vazão: $1,0 \mathrm{~mL}$ $\mathrm{min}^{-1}$, fase móvel: THF: TEA $0.5 \%(\mathrm{pH} \mathrm{3,0)}$ ajustado com ácido ortofosfórico (25:75 v/v); detecção UV de $280 \mathrm{~nm}$.

Figura 11 Cromatograma da solução de gemifloxacino $50,0 \mu \mathrm{g} \mathrm{mL}^{-1}$ após hidrólise em meio neutro após $2 \mathrm{~h}$. Condições: coluna LiChrospher $100 \mathrm{RP}-8 \mathrm{e}(5 \mu \mathrm{m}, 125 \times 4 \mathrm{~mm})$, vazão: $1,0 \mathrm{~mL}$ $\min ^{-1}$, fase móvel: THF: TEA 0,5\% (pH 3,0) ajustado com ácido ortofosfórico (25:75 v/v); detecção UV de $280 \mathrm{~nm}$. 
Figura 12 Cromatograma da solução de gemifloxacino $50,0 \mu \mathrm{g} \mathrm{mL}^{-1}$ após hidrólise em meio oxidativo após $2 \mathrm{~h}$. Condições: coluna LiChrospher 100 RP-8e $(5 \mu \mathrm{m}, 125 \times 4 \mathrm{~mm})$, vazão: $1,0 \mathrm{~mL}$ $\mathrm{min}^{-1}$, fase móvel: THF: TEA $0.5 \%(\mathrm{pH} \mathrm{3,0)}$ ajustado com ácido ortofosfórico (25:75 v/v); detecção UV de $280 \mathrm{~nm}$.

Figura 13 Cromatograma da solução de gemifloxacino $50,0 \mu \mathrm{g} \mathrm{mL}$ após hidrólise em meio ácido após $2 \mathrm{~h}$. Condições: coluna LiChrospher $100 \mathrm{RP}-8 \mathrm{e}(5 \mu \mathrm{m}, 125 \times 4 \mathrm{~mm})$, vazão: $1,0 \mathrm{~mL}$ $\mathrm{min}^{-1}$, fase móvel: THF: TEA $0.5 \%(\mathrm{pH} \mathrm{3,0)}$ ajustado com ácido ortofosfórico (25:75 v/v); detecção UV de $280 \mathrm{~nm}$.

Figura 14 Cromatograma da solução de gemifloxacino $50,0 \mu \mathrm{g} \mathrm{mL}$ após hidrólise em meio básico após $2 \mathrm{~h}$. Condições: coluna LiChrospher $100 \mathrm{RP}-8 \mathrm{e}(5 \mu \mathrm{m}, 125 \times 4 \mathrm{~mm})$, vazão: $1,0 \mathrm{~mL}$ $\mathrm{min}^{-1}$, fase móvel: THF: TEA $0.5 \%(\mathrm{pH} \mathrm{3,0)}$ ajustado com ácido ortofosfórico (25:75 v/v); detecção UV de $280 \mathrm{~nm}$.

Figura 15 Sobreposição dos cromatogramas da curva analítica nas concentrações de 35,0 a $65,0 \mu \mathrm{g} \mathrm{mL}^{-1}$. Condições: coluna LiChrospher $100 \mathrm{RP}-8 \mathrm{e}(5 \mu \mathrm{m}, 125 \times 4 \mathrm{~mm})$, vazão: $1,0 \mathrm{~mL}$ $\mathrm{min}^{-1}$, fase móvel: THF: TEA $0.5 \%(\mathrm{pH} \mathrm{3,0)}$ ajustado com ácido ortofosfórico (25:75 v/v); detecção UV de $280 \mathrm{~nm}$.

Figura 16 Curva de calibração do gemifloxacino na faixa de concentração de 35,0 a $65,0 \mu \mathrm{g} \mathrm{mL}^{-1}$.

Figura 17 Eletroferograma referente ao pico do gemifloxacino na concentração de $100,0 \mu \mathrm{g} \mathrm{mL}^{-1}$. Condições: voltagem de +18 $\mathrm{kV}$, temperatura de $18^{\circ} \mathrm{C}$. Condições: $5 \mathrm{~s}$ de injeção a $0.5 \mathrm{psi}$, e tampão de tetraborato de sódio $10 \mathrm{mmol} \mathrm{L}^{-1}$ e absorção UV em $280 \mathrm{~nm}$.

Figura 18 Eletroferogramas referente ao pico do gemifloxacino na concentração de 100,0 $\mathrm{g} \mathrm{mL}^{-1}$. Eletrólito de corrida de TBS na concentração de 40 a $60 \mathrm{mmol} \mathrm{L}^{-1}$. Condições: voltagem de $+18 \mathrm{kV}$, temperatura de $18^{\circ} \mathrm{C}$, introdução hidrodinâmica da amostra por 5 s a 0.5 psi e detecção no UV em $280 \mathrm{~nm}$.

Figura 19 Eletroferograma da solução de placebo Condições: capilar de sílica fundida com 40,2 cm (30 cm efetivo) $x 75 \mu \mathrm{m}$ (d.i.) $\times$ $375 \mu \mathrm{m}$ (d.e.); eletrólito: tampão tetraborato de sódio 50 mmol L-1 $(\mathrm{pH} 8,6)$; voltagem de $+18 \mathrm{kV}$; temperatura de $18^{\circ} \mathrm{C}$; introdução hidrodinâmica da amostra por $5 \mathrm{~s}$ a 0,5 psi e absorção UV em 263 nm.

Figura 20 Eletroferograma da solução de gemifloxacino $50,0 \mu \mathrm{g} \mathrm{mL}$ após $2 \mathrm{~h}$ de hidrólise em meio neutro. Condições: capilar de 
sílica fundida com 40,2 cm (30 cm efetivo) x $75 \mu \mathrm{m}$ (d.i.) $\mathrm{x}$ $375 \mu \mathrm{m}$ (d.e.); eletrólito: tampão tetraborato de sódio 50 $\mathrm{mmol} \mathrm{L}^{-1}(\mathrm{pH} 8,6)$; voltagem de $+18 \mathrm{kV}$; temperatura de $18^{\circ} \mathrm{C}$; introdução hidrodinâmica da amostra por $5 \mathrm{~s}$ a 0,5 psi e absorção UV em 263 nm.

Figura 21 Eletroferograma da solução de gemifloxacino $50,0 \mu \mathrm{gL}^{-1}$ após $2 \mathrm{~h}$ de hidrólise em meio oxidativo. Condições: capilar de sílica fundida com 40,2 cm (30 cm efetivo) x $75 \mu \mathrm{m}$ (d.i.) $x$ $375 \mu \mathrm{m}$ (d.e.); eletrólito: tampão tetraborato de sódio 50

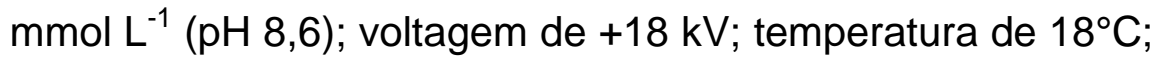
introdução hidrodinâmica da amostra por $5 \mathrm{~s}$ a 0,5 psi e absorção UV em $263 \mathrm{~nm}$.

Figura 22 Eletroferograma da solução de gemifloxacino $50,0 \mu \mathrm{g} \mathrm{mL}$ após $2 \mathrm{~h}$ de hidrólise em meio ácido. Condições: capilar de sílica fundida com 40,2 cm (30 cm efetivo) x $75 \mu \mathrm{m}$ (d.i.) $\mathrm{x}$ $375 \mu \mathrm{m}$ (d.e.); eletrólito: tampão tetraborato de sódio 50 $\mathrm{mmol} \mathrm{L}^{-1}(\mathrm{pH} 8,6)$; voltagem de $+18 \mathrm{kV}$; temperatura de $18^{\circ} \mathrm{C}$; introdução hidrodinâmica da amostra por $5 \mathrm{~s}$ a 0,5 psi e absorção UV em 263 nm.

Figura 23 Eletroferograma da solução de gemifloxacino $50,0 \mu \mathrm{gL} \mathrm{m}^{-1}$ após $2 \mathrm{~h}$ de hidrólise em meio básico. Condições: capilar de sílica fundida com 40,2 cm (30 cm efetivo) $x 75 \mu \mathrm{m}$ (d.i.) $\mathrm{x}$ $375 \mu \mathrm{m}$ (d.e.); eletrólito: tampão tetraborato de sódio 50 $\mathrm{mmol} \mathrm{L}^{-1}(\mathrm{pH} 8,6)$; voltagem de $+18 \mathrm{kV}$; temperatura de $18^{\circ} \mathrm{C}$; introdução hidrodinâmica da amostra por $5 \mathrm{~s}$ a 0,5 psi e absorção UV em 263 nm.

Figura 24 Sobreposição dos eletroferogramas da curva analítica nas concentrações de 35,0 a $65,0 \mu \mathrm{g} \mathrm{mL}^{-1}$, com adição de PI. Condições: capilar de sílica fundida com 40,2 cm $(30 \mathrm{~cm}$ efetivo) $\times 75 \mu \mathrm{m}$ (d.i.) $\times 375 \mu \mathrm{m}$ (d.e.); eletrólito: tampão

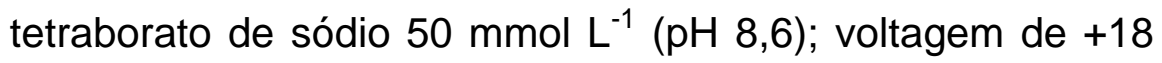
$\mathrm{kV}$; temperatura de $18^{\circ} \mathrm{C}$; introdução hidrodinâmica da amostra por $5 \mathrm{~s}$ a 0,5 psi e absorção UV em $263 \mathrm{~nm}$.

Figura 25 Curva de calibração do gemifloxacino na faixa de 79 concentrações de 35,0 a $65,0 \mu \mathrm{g} \mathrm{mL} \mathrm{m}^{-1}$. Padrão interno. metoprolol $\left(500,0 \mu \mathrm{g} \mathrm{mL}^{-1}\right)$. 


\section{LISTA DE TABELAS}

Página

Tabela 1 Parâmetros necessários para validação 25

Tabela 2 Padrões utilizados na validação 36

Tabela 3 Reagentes e solvents $\quad 37$

Ensaios realizados no desenvolvimento de metodologia por 40 CLAE

Tabela 5 Ensaios realizados no desenvolvimento de metodologia por CZE 44

Tabela 6 Obtenção da curva de calibração para o gemifloxacino 52

Diluição da solução de metoprolol utilizada como padrão interno 52 em EC

Tabela 8 Condições avaliadas nos testes de estresse 53

Tabela 9 Concentrações utilizadas para o ensaio de recuperação 58

Tabela 10 Resultados experimentais obtidos na determinação da curva 70 analítica do gemifloxacino. Método: CLAE

Resultados obtidos na determinação dos limites de detecção e 71

Tabela 11 quantificação do gemifloxacino. Método: CLAE

Tabela 12 Resultados ob

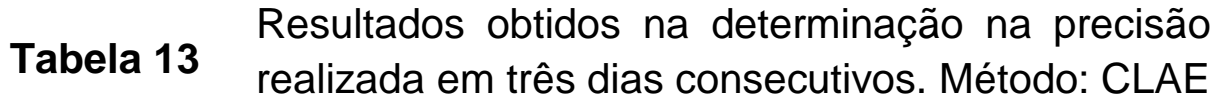

Tabela 14 Resultados obtidos no teste de recuperação do gemifloxacino. 73 Método: CLAE

Resultados experimentais obtidos na determinação da curva 80

Tabela 15 analítica do gemifloxacino. Método: CZE

Tabela 16 Resultados obtidos na determinação dos limim

Tabela 17 Resultados obtidos na determinação da repetibilidade da precisão. Método: CZE

Tabela 18 Resultados obtidos na determinação na

Tabela 19 Resultados obtidos no teste de recuperação do gemifloxacino. 82 Método: CZE

Tabela 20 Comparação das metodologias desenvolvidas 


\section{LISTA DE ABREVIATURAS E SÍMBOLOS}

\begin{tabular}{ll} 
ANVISA & Agência Nacional de Vigilância Sanitária \\
CLAE & Cromatografia Líquida de Alta Eficiência \\
$\mathbf{c m}$ & Centímetro \\
$\mathbf{C Z E}$ & Capillary zone electrophoresis \\
$\mathbf{C V}$ & Coeficiente de variação \\
$\mathbf{d . e .}$ & Diâmetro externo \\
$\mathbf{d . i .}$ & Diâmetro interno \\
$\mathbf{D N A}$-girase & Deoxyribonucleic acid - girase \\
$\mathbf{D P R}$ & Desvio padrão relativo \\
$\mathbf{E C}$ & Eletroforese capilar \\
$\mathbf{F D A}$ & Food and Drug Administration \\
$\mathbf{G M F L X}$ & Gemifloxacino \\
$\mathbf{g}$ & Grama \\
$\mathbf{H} \mathbf{O}_{2}$ & Peróxido de hidrogênio \\
$\mathbf{H C l}$ & Ácido clorídrico \\
$\mathbf{I C H}$ & International Conference on Harmonization \\
$\mathbf{k V}$ & Kilo Volt \\
$\mathbf{M e C N}$ & Acetonitrila \\
$\mathbf{M e O H}$ & Metanol \\
$\mathbf{m i n}$ & Minuto \\
$\mathbf{m g}$ & Miligrama \\
$\mathbf{m L}$ & Mililitro \\
$\mathbf{m m}$ & Milímetro \\
$\mathbf{m o l}$ & Mol \\
$\mathbf{m m o l}$ & Milimol \\
$\mathbf{n m}$ & Nanômetros \\
$\mathbf{N a O H}$ & Hidróxido de sódio \\
$\mathbf{n g}$ & Nanograma \\
$\mathbf{P I}$ & Padrão interno \\
\hline $\mathbf{m}$ &
\end{tabular}




\begin{tabular}{ll}
$\boldsymbol{r}$ & Coeficiente de correlação \\
TBS & Tetraborato de sódio \\
TEA & Trietilamina \\
THF & Tetraidrofurano \\
$\mathbf{t m}$ & Tempo de migração \\
$\mathbf{t r}$ & Tempo de retenção \\
$\mathbf{U V}$ & Ultravioleta \\
$\mathbf{U V}-\mathbf{v i s}$ & Ultravioleta Visível \\
$\mathbf{v} / \mathbf{v}$ & Volume/ volume \\
$\boldsymbol{\mu m}$ & Micrometro \\
$\boldsymbol{\mu g}$ & Micrograma \\
$\boldsymbol{\mu L}$ & Microlitro \\
$\boldsymbol{\mu g} \mathbf{m L - 1}$ & Micrograma por mililitros \\
$\% \mathbf{R}$ & Porcentagem de recuperação \\
$\%$ & Porcentagem \\
$\boldsymbol{\Lambda}$ & Lambda ( comprimento de onda) \\
$\overline{\boldsymbol{x}}$ & Média \\
$\boldsymbol{S}$ & Desvio padrão \\
${ }^{\circ} \mathbf{C}$ & Grau Celsius \\
$\boldsymbol{n}$ & Número de amostras \\
\hline &
\end{tabular}




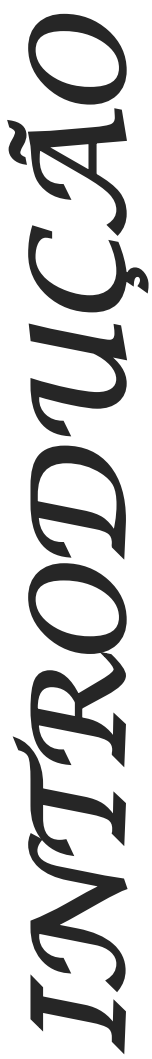




\section{INTRODUÇÃO}

Desde a descoberta da penicilina por Alexander Fleming em 1921, até meados dos anos 60, a terapia antibacteriana era baseada em medicamentos de origem natural. Em 1961, a descoberta do primeiro antibiótico sintético deu origem às primeiras quinolonas, que mesmo sendo muito eficazes, possuem limitações farmacocinéticas, como atingir concentrações adequadas somente nas vias urinárias e espectro de ação restrito a bactérias gram-negativas. Posteriormente, foi sintetizado o primeiro fármaco de uma subclasse das quinolonas, o norfloxacino, pela inserção de um átomo de flúor e um anel piperazínico no anel central das quinolonas. Esta subclasse recebeu o nome de quinolonas fluoradas, ou simplesmente fluorquinolonas.

Após verificar-se o amplo espectro de atividade, a boa cinética e resultados favoráveis das fluorquinolonas, nos anos seguintes foram dados continuidade à pesquisa e aprimoramento destes fármacos. São genericamente chamados de quinolonas, e, dentre eles estão as de segunda, terceira e quarta gerações, com as quais se continua buscando o combate a resistência das bactérias aos fármacos mais antigos. Os fármacos desenvolvidos posteriormente foram conseqüência de contínuos estudos e pesquisas em favor de melhoramentos das indicações, espectros de ação e combate a resistência bacteriana.

Antibacteriano da terceira geração das quinolonas, o gemifloxacino é uma das mais recentes fluorquinolonas desenvolvidas, tendo sido disponibilizada no mercado brasileiro em 2007, para o tratamento de infecções do trato respiratório. O gemifloxacino exerce ação bactericida, bloqueando a replicação do material genético bacteriano. Sua maior vantagem em relação a outros antibióticos é sua alta afinidade pela enzima bacteriana DNA-girase. Mesmo sendo recente, é um medicamento de primeira escolha para o tratamento de infecções, e considerado de grande importância na terapêutica.

Pelo levantamento bibliográfico, constatou-se a falta de métodos simples, econômicos e eficazes para a determinação quantitativa de gemifloxacino em comprimidos, com a finalidade de emprego na rotina de um laboratório de controle de qualidade de medicamentos. 
Um fator relevante ao uso de qualquer medicamento é passar para o paciente/cliente a certeza de sua qualidade, Um medicamento só pode ser considerado um produto de qualidade quando há determinado grau de semelhança com seu projeto inicial, ou seja, o protótipo.

Nos anos 80 e 90 foram estabelecidos o controle total de qualidade e suas normas legais. Desde então, estas exigências aplicadas em medicamentos vêem sido seguidas, fiscalizadas e aprimoradas continuamente.

Hoje, a maioria das formas farmacêuticas acabadas são misturas de princípios ativos e diversos materiais inertes (excipientes), assegurando assim, a qualidade, estabilidade, garantindo em inúmeras vezes, a aceitabilidade de um medicamento pelos pacientes. Apesar das vantagens destas complexas misturas, o controle de qualidade deve ser feito, o que só é possível se houver a separação completa das misturas.

Outro fator relevante é o crescimento acelerado de novas pesquisas e de novos produtos farmacêuticos mais elaborados e complexos lançados no mercado. Por este motivo as ferramentas e tecnologias utilizadas para assegurar a eficácia, segurança e qualidade de um medicamento devem acompanhar esse crescimento no mesmo ritmo de seu desenvolvimento.

Com a finalidade de garantir-se a qualidade de um processo e do produto final, deve-se realizar um conjunto de ensaios qualitativos e quantitativos, que assegurem a qualidade de todos os seus componentes, princípios ativos, embalagens, condições de armazenamento, produção e todo produto acabado. Além disso, cada processo, ensaio e análise devem ser validados, ou seja, comprovada a sua eficácia, segurança e confiabilidade perante os resultados esperados.

Vários órgãos competentes disponibilizam hoje guias para a validação de metodologias analíticas empregadas em fármacos. Todos concordam com os parâmetros mínimos que devem ser avaliados, tais como seletividade, linearidade, precisão e exatidão. O exemplo de guia utilizado é informado pela Resolução RE n ${ }^{\circ}$ 899 de 29 de maio de 2003, publicado pela Agência Nacional de Vigilância Sanitária (ANVISA), mesmo órgão responsável pela fiscalização da qualidade dos medicamentos produzidos no Brasil. 
A preocupação com a qualidade de antibióticos aumenta a importância dos laboratórios de controle de qualidade, em desenvolver e validar metodologias analíticas para identificar e quantificar estes fármacos.

O presente estudo tem por objetivo o desenvolvimento de métodos analíticos simples e eficazes, capazes de satisfazer as exigências quanto aos parâmetros mínimos de validação necessários para quantificação de gemifloxacino empregandose a eletroforese capilar (EC) e a cromatografia líquida de alta eficiência (CLAE). 


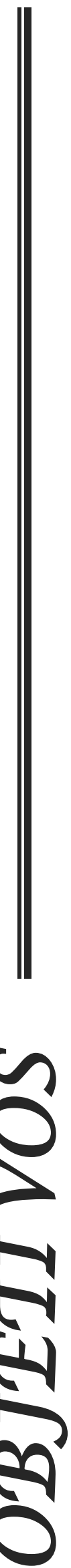




\section{OBJETIVOS}

O presente trabalho foi planejado visando o desenvolvimento e a validação de duas metodologias analíticas para a determinação quantitativa de gemifloxacino em preparações farmacêuticas. Portanto, os objetivos de pesquisa foram:

$\checkmark$ Desenvolver metodologia simples e eficiente para determinação quantitativa de gemifloxacino por cromatografia líquida de alta eficiência (CLAE);

$\checkmark$ Desenvolver metodologia simples e eficiente para determinação quantitativa de gemifloxacino através da eletroforese capilar de zona (CZE);

$\checkmark$ Validar as metodologias desenvolvidas;

$\checkmark$ Comparar as metodologias desenvolvidas e validadas; e

$\checkmark$ Aplicar as metodologias desenvolvidas para a determinação quantitativa de gemifloxacino, em comprimidos comercializados no Brasil. 


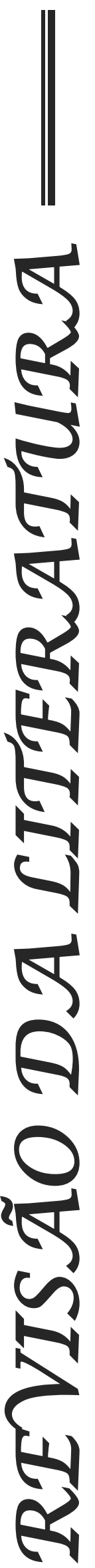




\section{REVISÃO DA LITERATURA}

\subsection{Fluorquinolonas}

Em 1949 Prince e col.(TAVARES, 2001) descreveram as quinolonas a partir de uma estrutura de quinoleína com ácido carboxílico e uma função cetona, mas esta substância não apresentou nenhuma atividade biológica.

A quinoleína está presente em diversos fármacos, inclusive na cloroquina. Em 1962 Lesher e col. (TAVARES, 2001) identificaram a presença de uma substância halogenada durante a síntese do agente antimalárico cloroquina, o ácido nalidíxico, com propriedades antibacterianas.

O espectro de ação do ácido nalidíxico se resume às bactérias gramnegativas, exceto a Pseudomonas aeruginosa e curto espectro das gram-positivas, sendo, portanto, restrito a infecções urinárias (GENNARO, 2004; TAVARES, 2001). Embora este nunca tenha sido amplamente utilizado no tratamento de infecções sistêmicas, forneceu a base química na qual mais de dez mil análogos foram identificados (O'DONNELL et al., 2004).

Novos compostos foram sintetizados com outras estruturas centrais para as quinolonas, além da quinoleína, a naftiridina, a cinolina e a piridopirimidina, contendo uma função cetona (TAVARES, 2001).

Em 1974 a descoberta do ácido pipemídico por Pesson e col. (TAVARES, 2001) deu origem às quinolonas de segunda geração. Assim, em 1980 foi sintetizada a primeira fluorquinolona, o norfloxacino. Os fármacos desta geração se limitam a atuar nas vias urinárias e intestino (CROSS et al., 1999).

Após verificar-se o amplo espectro de atividade, a boa cinética e resultados favoráveis das fluorquinolonas, nos anos seguintes, foi dada a continuidade à pesquisa e aprimoramento destes fármacos. São genericamente chamados de quinolonas, e, dentre eles estão as de terceira e quarta gerações, com as quais se continua buscando o combate a resistência das bactérias aos fármacos mais antigos (GENNARO, 2004). 
O nome fluorquinolonas surgiu da inserção de um átomo de flúor no carbono 6 no anel piperazínico da estrutura central das quinolonas. Em seguida foram realizadas variações nos carbonos 5 e 8 . Os agentes mais recentes apresentam grupos aminas ou metilas no carbono 5 e na posição 8 diferentes substituintes menores como flúor, cloro ou metila (GENNARO, 2004).

As fluorquinolonas de terceira geração, representadas por fármacos como ciprofloxacino e ofloxacino, são utilizadas no tratamento de infecções sistêmicas, devido ao seu espectro de ação ser capaz de atuar sobre os bacilos gram-negativos, incluindo Pseudomonas aeruginosa e estafilococos. Com um espectro de ação mais amplo, as fluorquinolonas mais recentes, de quarta geração são capazes de atuar sobre infecções por germes gram-negativos e bactérias gram-positivas (O'DONNELL et al., 2004; TAVARES, 2001)

Em geral as fluorquinolonas agem na enzima bacteriana responsável pela replicação ou transcrição de seu DNA, a DNA-girase, que provoca aumento do espiralamento negativo do DNA, causando uma ruptura da dupla hélice (SILVA, 2002). Por sua vez, as fluorquinolonas possuem como alvo primário o conjunto de enzimas bacterianas topoisomerase, responsável por manter o DNA bacteriano fisicamente, quimicamente e biologicamente ativo e estável. As mais recentes fluorquinolonas agem principalmente na enzima topoisomerase IV, e, como alvo de ação complementar, exercem também ação sobre a DNA-girase, aprimorando assim seu espectro de ação. Além disso, estes compostos apresentam propriedades farmacocinéticas melhores (O’DONNELL et al., 2004; HOOPER, 1998).

A classificação das quinolonas por gerações foi proposta por Walker (RANGE et al., 2004), para diferenciá-las sob o ponto de vista clínico, baseado na potência e no espectro da atividade antibacteriana.

Assim como o emprego abusivo e sem critério de qualquer outro antibacteriano, os microrganismos também criam resistência às quinolonas, devido a mutação, causando diminuição da afinidade das girases ou pela permeação do fármaco através da parede celular bacteriana (GOODMAN et al., 2007; SILVA, 2006).

Muitas vezes considerados fármacos de primeira escolha na terapêutica, as fluorquinolonas ganharam espaço e estão constantemente sendo alvos de novas pesquisas e interesse de laboratórios farmacêuticos. Na última década observou-se 
um rápido crescimento e, consequentemente, 0 aparecimento de novos medicamentos, como o gemifloxacino, uma das mais recentes fluorquinolonas aprovada pelo U.S. Food and Drug Administration (FDA) disponível no mercado (ELBASHIR et al., 2009; O'DONNELL et al., 2004).

\subsection{Gemifloxacino}

\subsubsection{Propriedades farmacológicas}

Números do Ministério da Saúde comprovam que a incidência de internações por pneumonias no Brasil em 2004 foi superior a 720 mil casos. Dados do II Consenso Brasileiro sobre Doença Pulmonar Obstrutiva Crônica mostram que casos de bronquite aguda representam a 5a maior causa de internação no Brasil, sendo responsável por mais de 10 mil óbitos ao ano. Já as infecções das vias aéreas superiores (sinusite) causaram mais de 6 mil internações/ano.

Este fármaco, comercializado na forma de mesilato de gemifloxacino, é utilizado no tratamento de infecções do trato respiratório inferior e superior causadas por Streptococcus pneumoniae (multi-drug resistant), Haemophilus influenzae, Haemophilus parainfluenzae, Moraxella catarrhalis, Mycoplasma pneumoniae, Chlamydia pneumoniae e Klebsiella pneumoniae. É indicado, portanto, no tratamento da exacerbação aguda de bronquites crônicas, sinusite aguda bacteriana e pneumonia adquirida (BALL et al., 2001).

\subsubsection{Farmacocinética}

O mesilato de gemifloxacino é administrado em doses orais únicas e diárias de $320 \mathrm{mg}$ através de comprimidos revestidos, com tratamento de cinco a sete dias. Após o terceiro dia de uso ocorre o equilíbrio, pelo acúmulo de gemifloxacino, após doses orais múltiplas de $640 \mathrm{mg}$.

A absorção do gemifloxacino pelo trato gastrointestinal é muito rápida, alcançando picos de concentração plasmática entre 0,5 e 2 horas após administração oral. Sua biodisponibilidade absoluta chega a $71 \%$, independentemente de ser administrado ou não, nas refeições. 
A ligação in vitro com as proteínas plasmáticas em voluntários saudáveis é de 60 a 70\%, independente da a concentração. Após administração, o gemifloxacino é difusamente distribuído pelo organismo. Sua penetração é ideal em tecidos e fluidos pulmonares, principalmente no plasma, macrófagos bronquioalveolares, líquido de revestimento epitelial e mucosa brônquica.

Sua metabolização ocorre no fígado em pequenas quantidades. Após esta etapa, $65 \%$ do composto inalterado é encontrado no plasma em até 4 horas após a administração. O restante (menos que 10\%) é composto por metabólitos como o Nacetil gemifloxacino, seu isômero e o carbamil glucoronida do gemifloxacino.

A excreção do mesilato de gemifloxacino, como composto inalterado e metabólitos, se dá por duas rotas, fezes e urina. Estudos comprovam que a média de meia-vida é de aproximadamente 7 horas (BALL et al., 2001; BALL et al., 2004).

\subsubsection{Farmacodinâmica}

O gemifloxacino exerce ação bactericida, bloqueando a replicação do material genético bacteriano por atuar sobre a enzima DNA girase, impedindo-a de distorcer a dupla hélice do DNA, bloqueando consequentemente a replicação do material genético. A maior vantagem do gemifloxacino em relação a outros antibióticos, é a alta afinidade deste fármaco pela enzima. A topoisomerase IV é outra enzima que este fármaco atua, impedindo a replicação, transcrição e recombinação bacteriana (BALL et al., 2004).

Outro mecanismo do gemifloxacino é atuar sobre a enzima topoisomerase IV, que é necessária para a replicação, transcrição, reparo e recombinação do DNA bacteriano. Desta maneira, exerce ação contra as bactérias Gram-positivas e Gramnegativas (BALL et al., 2004; CROSS et al., 1999).

\subsubsection{Propriedades físico-químicas}

Quimicamente, o gemifloxacino é conhecido como 7-[(4E)-3(aminomethyl)-4methoxyiminopyrrolidin-1-yl]-1-cyclopropyl-6-fluoro-4-oxo-1,8-naphthyridine-3carboxylic acid. Comercialmente é encontrado como sal mesilato na forma 
sesquiidratada. Sua forma empírica é $\mathrm{C}_{18} \mathrm{H}_{20} \mathrm{FN}_{5} \mathrm{O}_{4} \cdot \mathrm{CH}_{4} \mathrm{O}_{3} \mathrm{~S}$ e sua estrutura está apresentada na Figura 1.

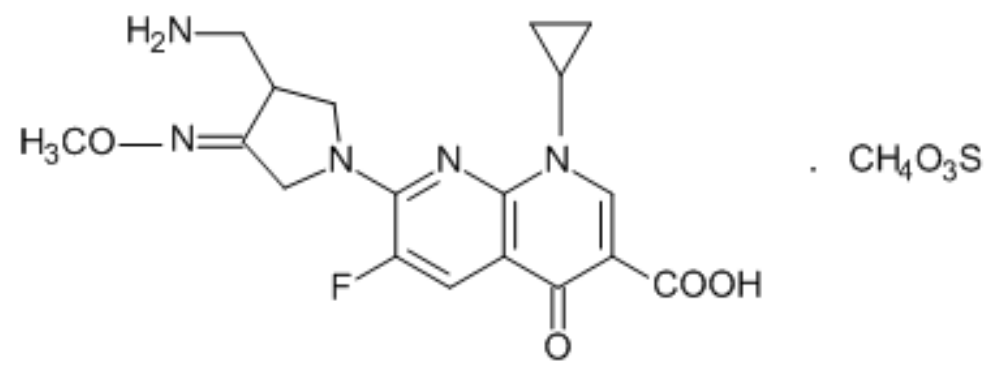

Figura 1 - Estrutura química do mesilato de gemifloxacino

O mesilato de gemifloxacino é sólido amorfo, de cor branca a amarelo-pálido e de caráter anfótero, livremente solúvel a $\mathrm{pH}$ neutro. Apresenta ponto de fusão de aproximadamente 235 a $237^{\circ}$ e possui pka 6,02 e 9,15 (DRUGBANK).

\subsubsection{Produto comercial}

No dia 04 de abril de 2003, nos Estados Unidos, o FDA aprovou e colocou em sua lista de novas entidades moleculares (NME) o fármaco mesilato de gemifloxacino, sob o nome comercial de Factive ${ }^{\circledR}$, produto da indústria farmacêutica Oscient Pharmaceuticals, do grupo LG Science for Life Ltd.

No Diário oficial da União de 05 de junho de 2006, o mesilato gemifloxacino, produzido pela Aché Laboratórios Farmaceuticos S.A., foi aprovado pela Agência Nacional de Vigilância Sanitária (ANVISA) como Medicamento Novo. Desta maneira foi autorizada a fabricação de Factive ${ }^{\circledR}$ no Brasil. Em meados de 2007, o produto foi disponibilizado no mercado brasileiro.

\subsection{Controle de qualidade}

Hoje, diversos conceitos subjetivos levam a uma única idéia de qualidade e GIL (2007) a define de forma simples: “... um conjunto de atributos que se deseja 
para um determinado produto. A satisfação das expectativas do cliente e o cumprimento de aspectos técnicos e de desempenho legalmente exigidos são dois fatores determinantes desse conceito." Mas levando em consideração o consumidor, dificilmente irá se obter um produto de alto padrão, pois as expectativas e necessidades são pessoais, por esse motivo se tem como um produto de qualidade aquele que atende suas especificações.

Antes da Segunda Guerra Mundial, a idéia de qualidade era simplesmente a ausência de defeitos do produto final. Com a evolução na área industrial e o aprimoramento no setor farmacêutico, em 1962, o Congresso dos Estados Unidos começou a exigir Boas Práticas de Fabricação de medicamentos. Seguindo esses passos, na década de 70 o Japão estabelece, além do controle de qualidade, o controle de processos.

Neste contexto histórico, o controle da qualidade passou por três diferentes fases: inspeção, controle estatístico e qualidade total. A inspeção de produtos em pequena quantidade era feita em todas as unidades produzidas. Com o advento da Revolução Industrial, o controle da qualidade de produtos fabricados em larga escala, deu origem ao processo de amostragem e localização de erros, a estatística foi a principal forma de análise e avaliação. Atualmente, o termo Controle Total (Integral) da Qualidade resume o esforço organizado dentro de uma empresa, constituindo o Sistema de Qualidade desta empresa.

Em laboratórios e indústrias farmacêuticas, quando se fala em Sistema de Qualidade engloba-se o Controle de Qualidade, as Boas Práticas de Fabricação e o Controle Total da Qualidade, a fim de se idealizar, produzir, manter e assegurar as características em cada unidade do produto através de padrões ou níveis de qualidade (GIL, 2007; SANTORO, 1988).

De acordo com a RDC 17 da ANVISA, o Controle de Qualidade pode ser definido como o conjunto de ensaios qualitativos e quantitativos realizados com 0 objetivo de avaliar matérias-primas, produtos intermediários, produtos acabados, materiais de embalagem e verificar se apresentam conformidade com as especificações estabelecidas. Portanto, o objetivo é examinar o produto, detectar o defeito, desvios e erros. Desta maneira, o Controle de Qualidade se resume em um trabalho de detecção (BRASIL, 2010; GIL, 2007). 
Outras atribuições do Controle de Qualidade é estabelecer, validar e implementar os procedimentos dentro da indústria, seguindo Procedimentos Operacionais Padrão aprovados e registrados (GIL, 2007).

A grande maioria das formas farmacêuticas acabadas são misturas de princípios ativos e diversos materiais inertes (excipientes), que asseguram a qualidade e a estabilidade do medicamento, garantindo assim a aceitabilidade, a eficiência, a confiabilidade e a segurança do paciente. Apesar das vantagens destas complexas misturas, o controle de qualidade deve ser feito, o que só é possível se houver a separação completa dos componentes destas formulações (LEITE, 2002).

O controle de qualidade se subdivide em microbiológico e físico - químico. Os ensaios realizados em laboratórios de controle físico-químico para avaliação qualitativa e quantitativa são basicamente ensaios de identificação, pureza, potência, físicos, estabilidade e técnicas analíticas para determinação quantitativa (GIL, 2007).

O tratamento estatístico de dados se tornou parte de qualquer procedimento, pois quando aplicado em qualquer fase do controle de qualidade auxilia na avaliação de um grande número de resultados e fatores experimentais utilizando cálculos matemáticos, reduzindo assim o trabalho, o tempo e o custo dos procedimentos (BARROS NETO et al., 2007).

\subsection{Métodos instrumentais}

Os métodos instrumentais tornaram-se ferramentas fundamentais para 0 controle de qualidade, tanto no laboratório físico-químico, como no microbiológico ou no controle de processos. A maior importância está no grande avanço tecnológico, o que possibilitou o aumento da sensibilidade dos métodos e agilidade na obtenção de resultados e avaliação de erros.

Dentre os principais métodos instrumentais utilizados atualmente no controle de qualidade destacam-se a espectroscopia de absorção UV-vísivel e infravermelho, fluormetria, polarimetria, técnicas eletroanalíticas (voltametria, polarografia, potenciometria, condutometria e titulações), absorção atômica, cromatografia líquida, cromatografia gasosa e outras técnicas cromatográficas acopladas a diversos sistemas de detecção. 
Além de todas as técnicas e suas derivações, o constante aprimoramento das técnicas existentes e o desenvolvimento de novas como a eletroforese capilar (EC) e a espectrometria de massas, facilitam as análises, mas exigem, cada vez mais, a capacitação e o treinamento específico e adequado dos profissionais do setor farmacêutico (GIL, 2007).

\subsubsection{Cromatografia líquida de alta eficiência}

Dentre os métodos instrumentais utilizados na separação, identificação e quantificação de componentes químicos, a cromatografia alcançou a confiança e espaço de destaque no setor farmacêutico (GIL, 2007).

A cromatografia é um método físico-químico de separação, no qual os analitos são separados através da passagem em duas fases: uma fase fixa de grande área superficial denominada fase estacionária, e outra um fluido que a percorre, denominada fase móvel. Com o passar dos anos foi sendo aprimorada e se subdividiu em diversas técnicas com o mesmo princípio, desde a cromatografia de camada delgada, a gasosa, por troca iônica, até umas das mais recentes a cromatografia líquida de ultra performance.

A cromatografia gasosa, uma das mais antigas possui uma limitação: a maioria dos compostos não são suficientemente voláteis ou se decompõe em altas temperaturas. Por esse motivo, a CLAE ganhou importância no campo da química analítica no controle de qualidade de medicamentos (COLLINS et al., 2006).

Conforme a Figura 2, o equipamento de CLAE é basicamente constituído de seis componentes. O reservatório de solventes (1) é o local onde se encontram os solventes da fase móvel que é impulsionada até a coluna cromatográfica por um sistema de bomba (2) composto de uma ou mais bombas de alta pressão. A coluna cromatográfica (4) é o local onde ocorre a separação da amostra que é introduzida através de um injetor (3) que se localiza entre a bomba e a coluna. A composição do efluente que passa pela coluna gera sinais elétricos através de um detector (5) e esses sinais são compilados em um processador de dados (6), um computador, que os transforma em um conjunto de picos conhecido como cromatograma (COLLINS et al., 2006; GIL, 2007). 


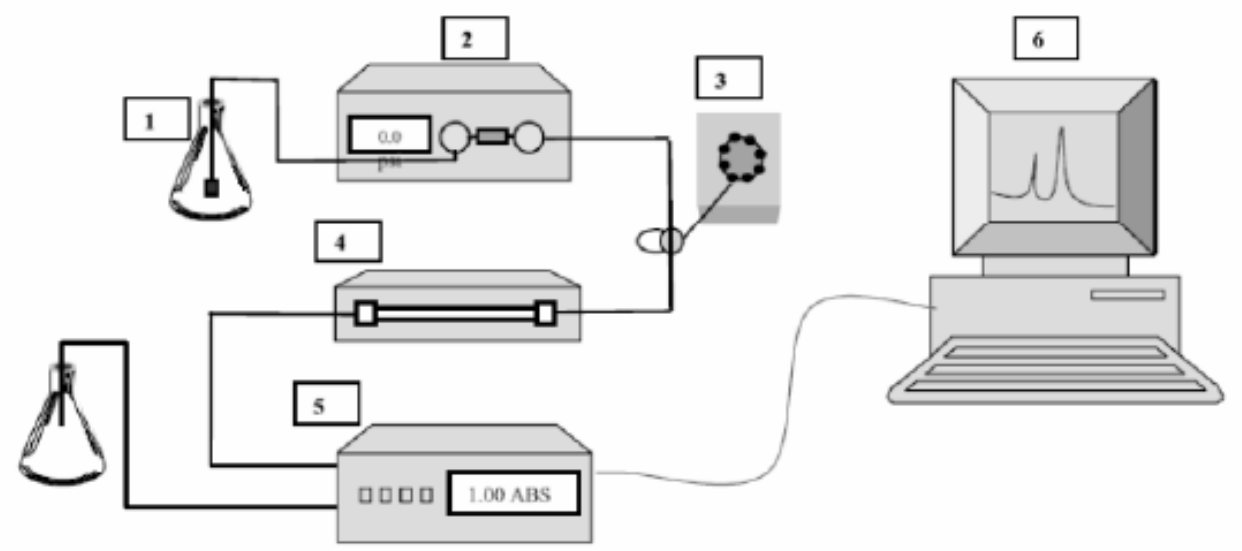

Figura 2. Representação de um equipamento de CLAE

Para realizar a separação de analitos utilizam-se colunas cromatográficas de aço inoxidável ou de plástico com comprimento 5 a $30 \mathrm{~cm}$ e diâmetro interno de 1 a $5 \mathrm{~mm}$. Estas colunas são empacotadas com a fase estacionária ou suportes que podem ser constituídos por diversos materiais.

Os suportes mais utilizados em CLAE são formados por partículas porosas de sílica de formato esférico, elevado grau de pureza e área superficial, e permeável aos solventes. Estas características tornam a coluna apropriada para separação de moléculas de baixa ou alta massa molar, permitindo ainda a formação de leitos estáveis às altas pressões e aumentando o tempo de vida útil de uma coluna que possui custo elevado (COLLINS et al., 2006; SNYDER et al., 1997).

Considerando que a fase móvel de um método por CLAE é a responsável por conduzir a amostra até a fase estacionária, a escolha dos solventes, concentração adequada e pH que a compõe são fatores essenciais para a obtenção de picos bem resolvidos e com eficiência.

As principais características de uma fase móvel são: não decompor ou dissolver a fase estacionária, não decompor, mas dissolver a amostra, apresentar baixa viscosidade e ponto de ebulição, ser compatível com o detector, ter miscibilidade completa quando mistura das e possuir alto grau de pureza. Cada solvente que pode compor uma fase móvel possui uma força peso que também influência nas análises, assim, quanto mais fraco o solvente maior a retenção de um analito na fase estacionária. 
Há dois principais modos de separação em CLAE: fase normal e fase reversa. A fase normal é composta por uma fase estacionária mais polar (com grupos amina, nitrila, ciano ou diol) do que a fase móvel. Outro diferencial é a composição da fase móvel, que é constituído por solventes orgânicos, sem adição de água, tornando-se mais cara, exceto quando utilizada para separação de compostos iônicos. As colunas são mais estáveis quando se utilizam de solventes não-aquosos. A maioria dos compostos orgânicos é solúvel nestes solventes e a pressão necessária, menor (SNYDER et al., 1997).

A mais utilizada é a fase reversa que consiste na utilização de uma fase estacionária de menor polaridade (octil, octadecil, silano, fenil, etc.) e uma fase móvel de maior polaridade, enquanto a fase normal, as polaridades são invertidas. Esta fase apresenta várias vantagens, tais como: uso de fases móveis menos tóxicas e de menor custo, como metanol e água, fases estacionárias estáveis de muitos tipos diferentes, rápido equilíbrio da coluna após a mudança da fase móvel, facilidade de empregar eluição por gradiente, maior rapidez em análises e boa reprodutibilidade dos tempos de retenção. Além disso, são muito aplicadas à separação de solutos de diferentes polaridades, massas molares e funcionalidades químicas (COLLINS et al., 2006).

As principais vantagens da CLAE são: alta eficiência através de picos estreitos e bem definidos, alta resolução, análises rápidas, baixos limites de detecção, versatilidade, mecanização, excelente reprodutibilidade e repetibilidade e obtenção de resultados qualitativos e quantitativos confiáveis. Esta técnica ainda pode ser melhorada com a capacidade de ser incorporada a outros sistemas de detecção como o detector de fluorescência e o espectrômetro de massas. A CLAE possui algumas limitações, tais como o custo da instrumentação e da operação, alto consumo de solventes e necessidade de profissionais capacitados (COLLINS et al., 2006; HARRIS, 2005).

Apesar das vantagens e desvantagens, a CLAE vem sendo amplamente utilizada na área farmacêutica para análises qualitativas e principalmente quantitativas, o que pode ser confirmado pelo número de trabalhos publicados e confiança na técnica por parte das indústrias e laboratórios farmacêuticos (HARRIS, 2005). 


\subsubsection{Eletroforese capilar}

Eletroforese é o método instrumental que possui como princípio o transporte de partículas eletricamente carregadas através de dois eletrodos. Primeiramente esse método foi descrito utilizando placas com géis, mas quando se tratava de compostos químicos e principalmente fármacos um fator limitante é a baixa resistência elétrica. Na década de 60 foi descrito um método empregando capilares preenchidos com gel, mas em 1981 foi descrito o primeiro método utilizando capilares ocos de sílica fundida, ficando conhecido como eletroforese capilar (EC) (GIL, 2007; SANTORO et al., 2000).

A EC pode ser extremamente útil para o controle de qualidade de medicamentos. A técnica vem sendo utilizada para a separação e análise quantitativa de vários compostos de modo simples e eficiente. Por isso vem sendo apontada como uma alternativa à CLAE (SANTORO et al., 2000).

Dentre as diversas vantagens da EC pode-se destacar a instrumentação (Figura 3) que é simples, onde, o capilar de sílica, com diâmetro interno de 15 a 100 $\mu \mathrm{m}$ e comprimento de 30 a $100 \mathrm{~cm}$, é preenchido com um eletrólito, normalmente composto com solução tampão. Em seguida a amostra é introduzida no capilar por injeção hidrodinâmica (pressão, vácuo ou gravidade) ou injeção eletrocinética (GIL, 2007; HARRIS, 2005; TAVARES, 1996).

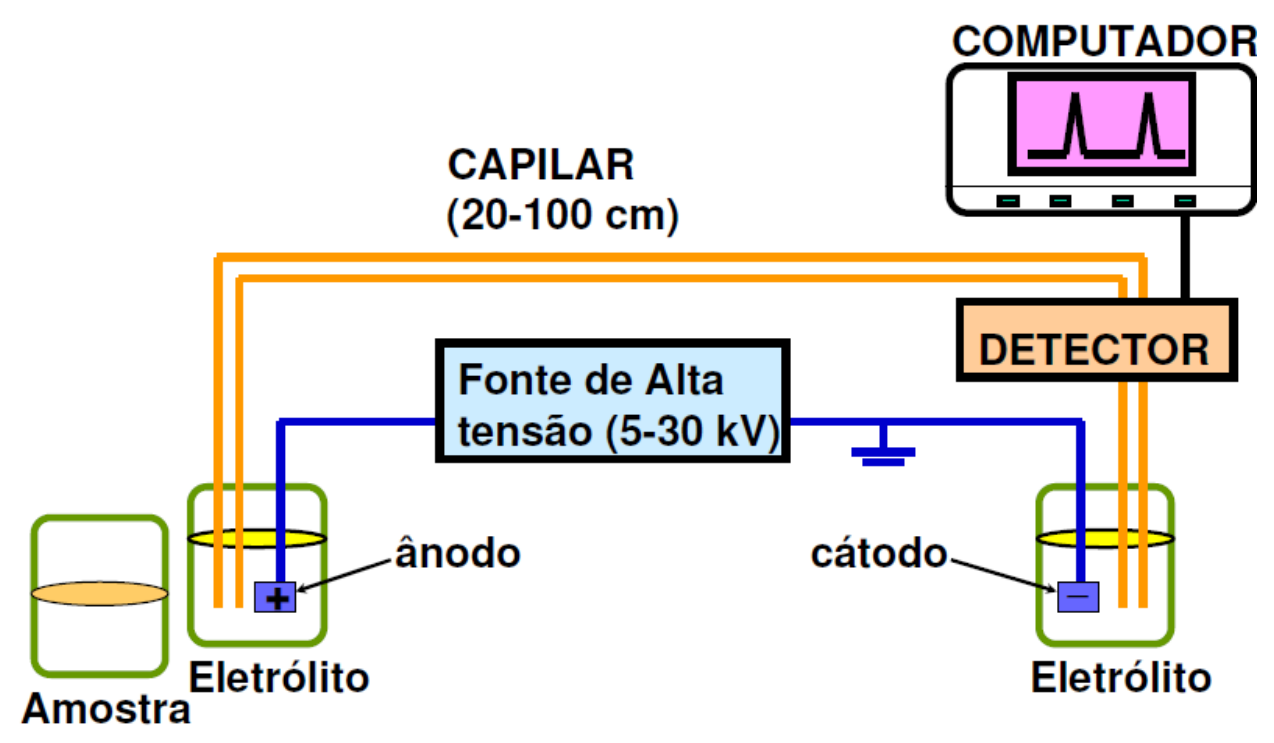

Figura 3. Representação da instrumentação da EC. 
Com a amostra dentro do capilar as duas extremidades (catodo e anodo) são mergulhadas em soluções de eletrólito juntamente com um eletrodo em cada lado, assim, um potencial elétrico (de $+10 \mathrm{a}+30 \mathrm{kV}$ ) é aplicado, gerando um campo elétrico, causando movimentos eletroforéticos e eletroosmóticos da amostra e do eletrólito.

A sílica do capilar causa a retenção e separação dos analitos desejados pela migração por diferença de potencial dos íons e em tempos de migração diferentes. Conforme ocorre a diferença dos tempos de migração, o analito passa por um detector (UV, UV-Visível, fluorescência, arranjo diiodo, etc.) que gera sinais. Através de um software específico compila estes sinais são compilados em um conjunto de picos, formando um eletroferograma (SANTORO et al., 2000; TAVARES, 1996).

A mobilidade eletroforética de uma espécie química é em geral determinada pelo seu tamanho e número de cargas dos íons. A mobilidade dos íons do soluto depende do tamanho das partículas, seguido do número de cargas iônicas. Assim sendo, um íon muito pequeno movimenta-se mais rapidamente do que um maior, com o mesmo número de cargas. Hipoteticamente, para separar íons com diferentes cargas e tamanhos, o menor e de maior carga sairá antes. A velocidade eletroforética, depende da diferença de potencial aplicada (TAVARES, 1996; TAVARES, 1997).

A mobilidade de um íon pode ser influenciada pelo seu valor de pKa. Assim quanto mais ionizado maior será sua mobilidade. Por este motivo a manipulação do $\mathrm{pH}$ tem um efeito marcante na mobilidade relativa dos íons (WATSON, 1999).

O fluxo eletroosmótico (FEO), representado na Figura 4, ocorre pela ionização dos grupos silanois da sílica (parede dos capilares) quando em contato com solução tampão. Em valores de $\mathrm{pH}$ muito altos, estes grupos se dissociam resultando em cargas negativas (grupos silanoatos) na superfície (ALTRIA, 1996). Os grupos silanoatos atraem íons carregados positivamente provenientes do tampão, que formam uma camada interna de cátions (camada fixa) perto da parede do capilar. Estes cátions não são suficientes para neutralizar todas as cargas negativas. Assim, uma segunda camada de cátions é formada (camada móvel). Quando uma tensão é aplicada, a camada móvel é puxada no sentido do cátodo. As moléculas de água que solvatam o analito também contribuem para seu deslocamento ao longo do capilar (SANTORO et al., 2000; WATSON, 1999). 


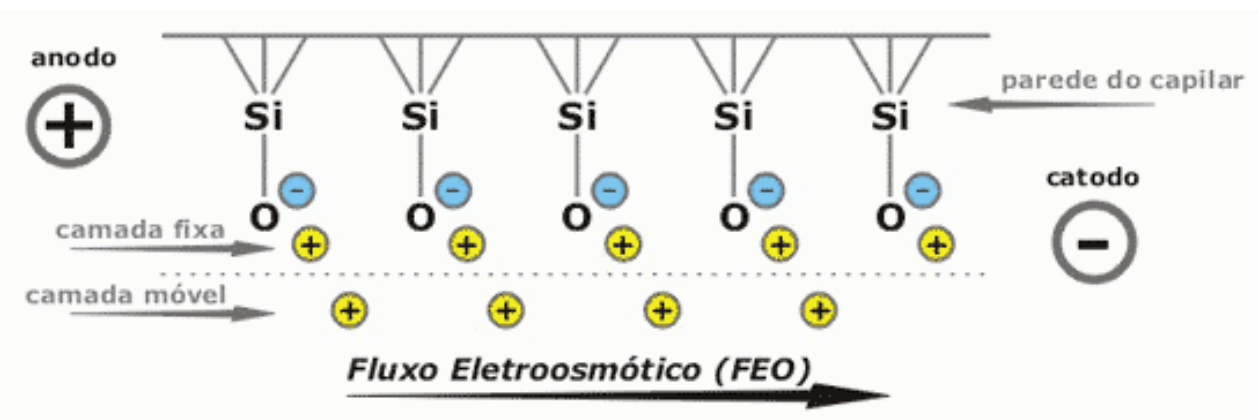

Figura 4: Esquema da formação e do sentido do fluxo eletroosmótico

A eletroforese capilar, na verdade, não é uma única técnica isolada. Ela deve ser encarada como diferentes técnicas fundamentadas no mesmo princípio de migração sob ação de um campo elétrico, mas com mecanismos de separação diferentes, tais como: a eletroforese capilar de zona ou solução livre (CZE), cromatografia eletrocinética micelar (MECC), eletroforese capilar por focalização isoelétrica (CIEF), eletroforese capilar de gel (CGE), Isotacoforese (CITP), eletrocromatografia (CEC) (SANTORO et al., 2000; TAVARES, 1997).

A CZE é o modo mais simples e mais utilizado na prática. O eletrólito é composto por uma solução tamponante, com uma maior homogeneidade e campo elétrico com força constante. A carga é dependente do meio e sofre alterações conforme as diferenças de $\mathrm{pH}$. A separação ocorre em zonas que seguem uma ordem de eluição: cátions (primeiro os com maior mobilidade), espécies neutras (não se separam) e por último os ânions (por último o que tem maior mobilidade) (KUHN, 1993).

Deve-se ressaltar que a EC pode oferecer vantagens significativas sobre as técnicas cromatográficas. Dentre elas destacam-se: requisição de pequeno volume de amostra, utilização de deteç̧ão por absorção da luz ultravioleta em comprimentos de onda menores do que $200 \mathrm{~nm}$ sem que haja aumento no ruído ou drift de linha de base, análise de uma vasta gama de compostos desde íons até macromoléculas utilizando a mesma coluna capilar em amostras injetadas na ordem de nanolitros ( $\mathrm{nL}$ ). Os instrumentos de EC e CLAE convencionais possuem custo equivalente, mas o custo operacional é significativamente menor na EC, principalmente pelo baixo consumo de solventes e baixo custo das colunas capilares (SANTORO et al., 2000; TAVARES, 1996). 
A EC já é utilizada como técnica de rotina em análises farmacêuticas, forenses, clínicas e ambientais, mas sua utilização tornou-se mais evidente com o projeto genoma humano e o sequenciamento de proteínas (HARRIS, 2005; SANTORO et al., 2000).

\subsection{Validação de metodologias analíticas}

A ANVISA, através da RDC 17, define validação como "ato documentado que atesta que qualquer procedimento, processo, equipamento, material, operação ou sistema, realmente conduza aos resultados esperados" (BRASIL, 2010).

A palavra validação originou-se do latim validus que significa forte e sugere que algo deve ser provado que é verdadeiro e útil, sendo assim aceito como padrão. Desta maneira, este termo refere-se a capacidade de medir o "real" ou a capacidade que um instrumento tem de evitar o erro (ARAUJO, 2009).

Para métodos analíticos, a discussão a respeito da validação começou a ser discutida nos anos 40, quando estudos pela American Chemical Society e Merck \& Co. apontaram o uso da análise matemática e estatística como pré-requisito para um desenvolvimento analítico eficaz (ARAUJO, 2009).

No início dos anos 70, trabalhos científicos apontaram a necessidade de que todo procedimento possuísse um conjunto de características mínimas e padronizadas necessárias para a obtenção de métodos analíticos confiáveis. Hoje, esses parâmetros são estabelecidos por diversos laboratórios de referência e agências reguladoras que fornecem guias e orientações para validação de métodos analíticos e temas relacionados.

Os principais e mais utilizados guias para validação de métodos analíticos e de processos, principalmente para a área farmacêutica, são oferecidos por associações de química analítica e agências reguladoras: Association of Official Analytical Chemists (AOAC), American Society for Testing and Material (ASTM), Codex Committee on Methods of Analysis and Sampling (CCMAS), European Committee for Normalization (CEN), Cooperation on International Traceability in Analytical Chemistry (CITAC), European Cooperation for Accreditation (EA), Food and Agricultural Organization (FAO), United States Food and Drug Administration 
(FDA), International Laboratory Accreditation Cooperation (ILAC), Organização Mundial da Saúde (OMS), International Organization for Standardization (ISO), International Union of Pure and Applied Chemistry (IUPAC), United States Pharmacopeia (USP), International Conference on Harmonization (ICH) e no Brasil, pela Agência Nacional de Vigilância Sanitária (ANVISA) e Instituto Nacional de Metrologia, Normalização e Qualidade Industrial (ARAUJO, 2009).

Ribani (2004) transcreve que as definições de validação estão em constante evolução de agências reguladoras vigentes:

"A validação deve garantir, através de estudos experimentais, que o método atenda às exigências das aplicações analíticas, assegurando a confiabilidade dos resultados" (ANVISA).

"Validação é o processo de definir uma exigência analítica e confirmar que o método sob investigação tem capacidade de desempenho consistente com o que a aplicação requer" (Eurachem Working Group).

"Confirmação por testes e apresentação de evidências objetivas de que determinados requisitos são preenchidos para um dado uso intencional" (ISO/IEC 17025).

A validação de métodos assegura sua credibilidade durante o uso rotineiro, sendo algumas vezes mencionado como o "processo que fornece uma evidência documentada de que o método realiza aquilo para o qual é indicado para fazer" (USP).

"Avaliação sistemática de um procedimento analítico para demonstrar que está sob as condições nas quais deve ser aplicado" (OMS).

Dentre diversas definições, o International Conference on Harmonization $(\mathrm{ICH}, 2005)$ foi resultado de uma conferência realizada por representantes de indústrias e agências reguladoras dos EUA, Europa e Japão, na tentativa de harmonizar todas as definições, parâmetros, requerimentos para metodologias analíticas com aplicações farmacêuticas. Com essa base, cada país tem sua legislação e procedimentos. Mesmo assim, todos apresentam o mesmo objetivo: demonstrar que as análises executadas fornecem resultados que permitam uma avaliação dos parâmetros especificados de qualidade do produto, assegurando a 
implantação do método e verificando a confiabilidade dos resultados analíticos em função do procedimento utilizado (RIBANI et al., 2004; SHABIR, 2003).

\subsubsection{Pré-validação}

A garantia de um bom método é uma validação eficaz. No entanto, para se ter essa garantia é necessário que sejam estabelecidos alguns passos e adequar as condições em uma pré-validação, e sendo que, primeiramente é se necessário definir-se o objetivo do método. (SHABIR, 2003).

$\mathrm{Na}$ definição do objetivo devem-se considerar as condições laboratoriais, equipamentos, local de realização e frequência com que o método será utilizado. Estes fatores influenciam no tipo de estudo de validação, limitando o trabalho para o que é realmente necessário (RIBANI et al., 2004).

Além da definição do objetivo, na pré-validação de um estudo, deve-se estabelecer a qualificação e a adequação do sistema, amostragem, preparação de amostras, condições de análises e avaliação de resultados. Dessa forma, o propósito da pré-validação resume-se em determinar a melhor forma de alcançar o objetivo da validação, e, assim documentar o método como adequado para sua finalidade (ARAUJO, 2009; SHABIR, 2003).

\subsubsection{Qualificação do sistema}

$\mathrm{O}$ ato de qualificar um sistema permite verificar se o instrumento, o material (reagentes, padrões, etc.), os analistas (treinamento), etc., estão adequados para atender o objetivo final da validação da metodologia (SHABIR, 2003).

\subsubsection{Preparo de amostras}

O preparo adequado de soluções padrão, de amostragem e tratamento da amostra representa de 60 a $80 \%$ do sucesso de um método analítico, tanto relacionado tanto ao manuseio quanto ao custo operacional (ARAUJO, 2009).

Considera-se parte do preparo de padrões e amostras o processo de amostragem, a característica do analito, as concentrações analíticas, a matriz, o tamanho da amostra e a técnica instrumental (SHABIR, 2003). 


\subsubsection{Condições de análise}

A validação de um método proposto é baseada em condições de preparo, tratamento de amostras e instrumentação bem definidas e documentadas, com o objetivo de extração de informações qualitativas e/ou quantitativas com um nível de incerteza aceitável (ARAUJO, 2009).

A definição das condições de análise, geralmente, são baseadas em testes preliminares e algumas considerações como propriedades químicas, concentração dos analíticos e amostra, velocidade, custo da análise, etc. (ARAUJO, 2009).

De modo geral, uma análise pode ser visualizada como um sistema de três elementos, ou seja, entrada, conversão e saída. Em geral, a entrada e saída são designadas pelas letras $x$ e $y$ e representam a concentração e a resposta experimental, respectivamente (ARAUJO, 2009).

\subsubsection{Avaliação de resultados}

O propósito da avaliação de resultados é extrair informações úteis e tirar conclusões sobre o processo de validação em geral, através da realização de uma compilação de um conjunto de dados com abordagens matemáticas e estatísticas (ARAUJO, 2009).

\subsubsection{Parâmetros de validação}

A literatura possui um amplo número de guias para avaliação de desempenho de métodos analíticos, apresentando diferentes terminologias e formas de expressar resultados. Apesar destas variações, todas levam a um mesmo propósito (TAVENIERS et al., 2004).

Cada método analítico possui suas variações e determinantes, principalmente devido às diferentes necessidades de cada caso. Por esses motivos, no General Chapter <1225>, a USP (2010) dividiu em quatro categorias os parâmetros, (Tabela 1), necessários para os diferentes propósitos da validação, onde:

$>$ Categoria 1: Procedimento para quantificação de fármacos, excipientes ou ingredientes ativos (incluindo conservantes) em produtos farmacêuticos; 
$>$ Categoria 2: Procedimento para determinação de impurezas, incluindo os ensaios quantitativos e testes limite;

> Categoria 3: Procedimentos analíticos para determinação de desempenho de ensaios como, dissolução, desintegração, etc.;

Categoria 4: Testes de identificação.

Tabela 1. Parâmetros necessários para validação

\begin{tabular}{lccccc}
\hline \multicolumn{1}{c}{ Parâmetros de } & Categoria & \multicolumn{2}{c}{ Categoria II } & Categoria & Categoria \\
desempenho analítico & I & Quantitativa & Testes Limite & III & IV \\
\hline \hline Exatidão & Sim & Sim & $*$ & * & Não \\
Precisão & Sim & Sim & Não & Sim & Não \\
Seletividade & Sim & Sim & Sim & $*$ & Sim \\
Limite de detecção & Não & Não & Sim & $*$ & Não \\
Limite de quantificação & Não & Sim & Não & $*$ & Não \\
Linearidade & Sim & Sim & Não & $*$ & Não \\
Curva analítica & Sim & Sim & $*$ & $*$ & Não \\
\hline \hline
\end{tabular}

${ }^{*}$ Pode ser requerido, depende da natureza do teste de especificidade

\subsection{Seletividade}

De acordo com o guia de validação do $\mathrm{ICH}$ (2005), seletividade é o teste realizado com o placebo para a avaliação da presença de analito, impurezas, produtos de degradação, etc. presentes na matriz da amostra, que possam interferir no resultado final do analito em questão, garantindo que a resposta seja, exclusivamente, a do composto de interesse.

A seletividade frequentemente é confundida com o termo especificidade. Para corrigir esta situação desnecessária, a IUPAC (International Union of Pure and Applied Chemestry) sugere o uso de somente o termo seletividade, mas mesmo assim, órgãos reguladores ainda utilizam o termo especificedade (RIBANI, 2004). 
Há diversos procedimentos para a determinação da seletividade. Uma das formas é comparando-se a matriz isenta da substância de interesse (placebo), com a matriz adicionada de padrão de interesse, sendo que, neste caso não deve apresentar interferentes eluindo no mesmo tempo de retenção que o analito, bem como deve-se apresentar bem separada dos demais compostos presentes na amostra. Outra maneira de identificar e determinar os compostos é submeter a amostra a condições de estresse utilizando variação de temperatura e meios ácido e alcalino, avaliando-se os produtos de degradação que possam interferir no resultado final (RIBANI et al., 2004).

\subsection{Exatidão}

Exatidão é a medida que representa o grau de concordância entre a determinação de um analito (valor real ou encontrado) e seu padrão (valor verdadeiro) (TAVENIERS et al., 2004).

A forma de sua medida varia de acordo com o ensaio realizado. Os mais utilizados são: materiais de referência, comparação de métodos adição de padrão e testes de recuperação (RIBANI et al., 2004).

\subsection{Precisão}

A precisão de um método analítico indica a dispersão de resultados entre ensaios independentes, repetidos de uma mesma amostra ou padrões, sob condições definidas. Esse parâmetro é expresso através do desvio padrão relativo (DPR) ou coeficiente de variação (CV), ambos em percentagem (\%) (ICH, 2005).

Para a determinação da precisão os guias de validação recomendam três ensaios distintos: repetibilidade, precisão intermediária e reprodutibilidade.

A repetibilidade é avaliada através dos resultados obtidos em determinações de um analito sob as mesmas condições experimentais e operacionais em um curto intervalo de tempo. Na precisão intermediária, sob as mesmas condições, o analito é analisado quanto as variações de dias, analistas ou equipamentos. A reprodutibilidade avalia a diferença entre resultados de diferentes laboratórios (USP, 2010). 


\subsection{Limite de detecção}

Limite de detecção é a menor concentração do analito numa amostra que pode ser detectado, e não necessariamente quantificado, sob as condições experimentais definidas (USP, 2010).

\subsection{Limite de quantificação}

Limite de quantificação é a menor concentração de um analito que pode ser quantitativamente determinada com precisão e exatidão, sob condições experimentais definidas. Geralmente, esse teste é utilizado para determinação de impurezas ou produtos de degradação em uma matriz (USP, 2010; TAVENIERS et al, 2004).

\subsection{Linearidade}

É o parâmetro analítico que avalia a capacidade do método de fornecer resultados diretamente proporcionais a concentração do analito (USP, 2010).

\subsection{Robustez}

Robustez é o ensaio que mede a sensibilidade do método frente a variações das condições de análise definidas. Portanto, diz-se que um método é robusto quando o resultado final não é afetado por pequenas e deliberadas modificações em seus parâmetros (USP, 2010).

\subsection{Revisão das metodologias publicadas para quinolonas}

\subsubsection{Cromatografia líquida de alta eficiência}

$\mathrm{Na}$ área farmacêutica, a CLAE possui um campo de utilização extenso e diversificado. Como exemplos podem ser citados os ensaios de biodisponibilidade e bioequivalência e as análises qualitativas e quantitativas no controle de qualidade, nos quais a CLAE é empregada como técnica analítica de escolha frequente. 
Doyle e colaboradores (2000) descreveram o primeiro método para quantificação de gemifloxacino em plasma humano por CLAE acoplada a espectrômetro de massas. Esse sistema de detecção mostrou maior eficiência para fluidos biológicos que necessitam de maior sensibilidade. A faixa linear foi de $10 \mathrm{a}$ $5000,0 \mathrm{ng} \mathrm{mL}^{-1}$. Este método foi validado utilizando-se um fluxo de $1 \mathrm{~mL} \mathrm{~min}^{-1}$ e uma fase móvel contendo $0,01 \mathrm{~mol} \mathrm{~L}^{-1}$ de tampão acetato de amônio $(\mathrm{pH} 2,5)$ : acetonitrila $(\mathrm{MeCN})(30: 70, \mathrm{v} / \mathrm{v})$.

Rote e Pingle (2009) também desenvolveram e validaram um método para determinação de gemifloxacino em fluidos biológicos utilizando a CLAE. A curva analítica foi de 30,0 a 600,0 $\mathrm{ng} \mathrm{mL}^{-1}$, com fase móvel composta por metanol (MeOH): acetato de sódio 1\%: ácido ortofosfórico $(65: 35: 0.5, \mathrm{v} / \mathrm{v} / \mathrm{v})$. Esse método foi comparado com um método por cromatografia delgada de alta eficiência e comprovou ser um método sensível e seletivo.

Santoro e colaboradores (2006) validaram um método para a separação de quatro fluorquinolonas utilizando uma coluna $\mathrm{C} 18$ e fase móvel contendo $0.3 \%$ de trietilamina: MeCN (80:20, v/v) com vazão de $1.0 \mathrm{~mL} \mathrm{~min}^{-1}$. Os resultados apresentaram-se satisfatórios, com recuperação acima de $99.5 \%$ e precisão com RSD menor do que $1 \%$.

Rajane e colaboradores (2010) validaram um método em CLAE utilizando uma coluna HiQ-SiL C8 e fase móvel de ortofosfato de potássio a $10 \mathrm{mmol} \mathrm{L}^{-1}(\mathrm{pH}$ ajustado para 3.0): acetonitrila na proporção 65:35 (v/v) em vazão de $1.0 \mathrm{~mL} \mathrm{~min}^{-1}$. Os resultados mostraram boa precisão (DPR 0,716\%) e recuperação $(99,73 \%)$. O estudo de estabilidade por estresse foi reproduzido neste trabalho para ambas as metodologias.

\subsubsection{Eletroforese capilar}

Utilizando EC como metodologia analítica para quantificação de quinolonas, o primeiro artigo foi publicado em 1993, por pesquisadores ingleses do grupo de Altria, o qual utilizou o ciprofloxacino como objeto de estudo. Desde então, diversos trabalhos foram publicados com diferentes finalidades aprimorando a técnica para análise de todas as classes das quinolonas. 
A maioria dos artigos publicados utilizam a CZE como técnica da EC e outros poucos utilizam a cromatografia capilar eletrocinética (MECK). As detecções variam com absorção UV, arranjo de diiodo e fluorescência induzida por laser.

Diversas análises foram realizadas nestes estudos, desde a rotineira análise em formas farmacêuticas, até análise em fluidos biológicos, em tecidos, estudo de fotodegradação e avaliação de pH e pka, visto que a ação das quinolonas é dependente do pH e pka próprios e do meio.

Os capilares utilizados para separação são finos, sensíveis e reaproveitáveis, sendo também mais baratos em relação a colunas de CLAE. Na revisão bibliográfica, os capilares que foram utilizados nos trabalhos de quinolonas são de 30 a $50 \mathrm{~cm}$ efetivos, com 50 e $75 \mu \mathrm{m}$ de diâmetro interno.

Os eletrólitos mais utilizados são tampão fosfato e tetraborato de sódio, em pH entre 6,0 e 10, conforme demonstrado por Faria e colaboradores (2006) e Barrón e colaboradores (2001), que estudaram a separação dos analitos e a variação da mobilidade respectivamente. Por outro lado, foi observado que, para algumas metodologias como para Awadallah e colaboradores (2003), o pH baixo apresentou boa resposta. Também foram utilizados diferentes aditivos, como ácido bórico, acetonitrila, metanol e dodecil sulfato de sódio.

Faria e colaboradores (2006) separaram cinco quinolonas, com boa resolução, utilizando mistura de tampão tetraborato de sódio $25 \mathrm{mmol} \mathrm{L}^{-1} \mathrm{com}$ tris/hidroclorídrico $25 \mathrm{mmol} \mathrm{L}^{-1}$, em $\mathrm{pH}$ ajustado para 8,87, no menor tempo encontrado, de três minutos. Em outros artigos, o tempo varia de 6,5 a 20 minutos.

A dependência dos outros parâmetros a serem ajustados varia de acordo com as condições de análise, tampão e técnica.

Cada quinolona apresenta uma absorção característica, portanto, as detecções UV variam entre 214 e $280 \mathrm{~nm}$.

Michalska e colaboradores (2004) desenvolveram uma metodologia para separação do ciprofloxacino e suas impurezas, utilizando tampão fosfato em $\mathrm{pH}$ 6,0 com sal de ácido pentano - 1 - sulfônico de sódio $75 \mathrm{mmol} \mathrm{L}^{-1}$. Das sete impurezas previstas, conseguiu-se separar quatro, aplicando-se uma voltagem baixa de $15 \mathrm{kV}$ a $25^{\circ} \mathrm{C}$. As quatro impurezas foram separadas em uma análise de 13 minutos. 
Foi observado que nas metodologias propostas e encontradas na literatura, havia variação do modo de injeção no equipamento (hidrodinâmica e eletrocinética).

Awadallah e colaboradores (2003) quantificaram os enantiômeros S e R do ofloxacino, utilizando um método que apresentou boa resposta na validação. Para tanto, os autores utilizaram tampão fosfato $50 \mathrm{mmol} \mathrm{L}^{-1} \mathrm{com} \mathrm{pH} \mathrm{2,8} \mathrm{contendo} 4 \%$ de seletor quiral metil - $\beta$ - ciclodextrina. Nesta metodologia, sendo uma exceção entre as outras, utilizou-se um comprimento de onda de $300 \mathrm{~nm}$. A introdução da amostra foi por 20 segundos a 0,5 psi, para a injeção hidrodinâmica. Para comparação, foi aplicada uma voltagem de +10 kV por 20 segundos e separação a $+20 \mathrm{kV}$. A injeção eletrocinética ofereceu melhores condições envolvendo menor faixa de concentração, em seis minutos de análise.

Utilizando CZE com detecção de arranjo diodo para separação de três

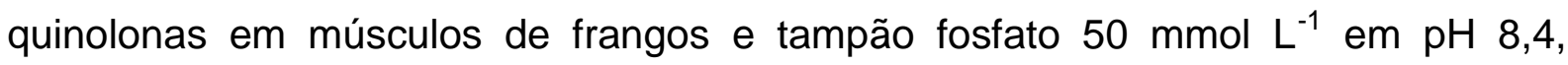
Beltrán e colaboradores (2003) obtiveram bons resultados utilizando calibrações multivariadas, e espectros sobrepostos.

Os parâmetros que podem interferir na eficiência e resolução dos picos foram detalhadamente descritos nos trabalho de Sun colaboradores. Utilizando tampão tetraborato de sódio $25 \mathrm{mmol} \mathrm{L}^{-1}+$ ácido bórico $25 \mathrm{mmol} \mathrm{L}{ }^{-1}+$ fosfato $25 \mathrm{mmol} \mathrm{L}^{-1}$ para separar sete quinolonas. Primeiramente foi avaliado o efeito da voltagem, em uma faixa de +18 a $+30 \mathrm{kV}$. Foi observado então que em $+18 \mathrm{kV}$ houve separação de seis quinolonas em um tempo de análise maior do que as outras. Com $+22 \mathrm{kV}$ houve boa separação. Acima de $+26 \mathrm{kV}$ a corrente aumentou, diminuindo o tempo de migração e aumentando o efeito Joule, o que diminuiu a eficiência da separação.

Avaliando-se a temperatura em uma faixa de 15 a $30^{\circ} \mathrm{C}$ observou-se que quanto menor a temperatura, maior o tempo de migração e a resolução dos picos, mas em $15^{\circ} \mathrm{C}$ um dos picos não foi a resposta esperada. Por este motivo, escolheuse $20^{\circ} \mathrm{C}$. Deste modo, foi obtida a separação de sete quinolonas por CZE e detecção de arranjos diodos em tecido suíno.

Barbosa e colaboradores (1998) estudaram o comportamento das quinolonas empregendo a EC em relação ao $\mathrm{pH}$ e as constantes de ionização (pKa). Utilizando mínimos parâmetros experimentais, foram identificados os pKas, com tampão fosfato $(\mathrm{pH} 11,0)$ e borato $\left(\mathrm{pH} \mathrm{10,5)} 25 \mathrm{mmol} \mathrm{L}^{-1}\right.$. 
Barrón e colaboradores (2001) calcularam as constantes de dissociação de nove quinolonas em misturas de metanol e água em diversas concentrações. Boa resolução foi encontrada em 15 minutos de análise utilizando tampão fosfato 25 mmol L ${ }^{-1}$ em metanol : água (30:70), ajustado com pH 6,5 ajustado com hidróxido de sódio $0,1 \mathrm{mmol} \mathrm{L}^{-1}$.

Levando-se em consideração as informações obtidas por Barrón e colaboradores (2001), Jiménez-Lozano e colaboradores (2001) determinaram o pKa a partir da mobilidade de 12 quinolonas a fim de conseguir uma melhor precisão. Foi observado que os valores de pKa aumentam com o aumento da concentração de metanol, principalmente por ser um fator regido por interações eletrostáticas.

Lin e colaboradores (2004), compararam seis quinolonas com o substituinte piperazinil em sua estrutura com duas quinolonas que não possuem este substituinte a fim de avaliar o comportamento do $\mathrm{pKa}$.

Para tanto foi utilizado tampão fosfato, comprovando que o pKa das quinolonas sofrem interferência por parte do tampão. As quinolonas com substituinte piperazinil estão envolvidas com três tipos de equilíbrios de protonação/ desprotonação.

Moller e colaboradores (1998) utilizaram detecção por fluorescência induzida por laser para aplicação em fluidos biológicos e constataram que a reprodutibilidade era a mesma empregando a EC e a CLAE, mas com maior escala de curva analítica e melhor relação tempo/custo, o que fez da EC uma alternativa para análise de moxifloxacino em fluidos biológicos.

Fierens e colaboradores (2001) obtiveram por CZE a separação de oito quinolonas da primeira e segunda geração em 15 minutos de análise, utilizando tampão fosfato $125 \mathrm{mmol} \mathrm{L}^{-1}$ em $\mathrm{pH} \mathrm{7,0}$. O método foi validado e aplicado em formulações farmacêuticas e poderá ser aplicado na rotina de um laboratório de controle de qualidade.

Para utilizar CZE para separação quiral de quatro fluorquinolonas, Zhou e colaboradores (2006) utilizaram o seletor quiral hidroxipropil - $\beta$ - ciclodextrina. Como tampão foi utilizado fosfato de sódio $70 \mathrm{mmol} \mathrm{L}^{-1}$ e $40 \mathrm{mmol} \mathrm{L}^{-1}$ do seletor quiral, obtendo em até 17 minutos a separação das quinolonas. 
A técnica de EC também foi aplicada em trabalhos, utilizando a detecção por quimiluminiscência, como por exemplo, para estudos farmacocinéticos do norfloxacino e levofloxacino em urina, realizado por Liu e colaboradores (2008). Utilizando um tampão fosfato de sódio $20 \mathrm{mmol} \mathrm{L}^{-1} \mathrm{em} \mathrm{pH} 8,0$. Obteve-se um método simples e fácil para utilização em análise bioquímica.

Outro método com a mesma detecção foi desenvolvido por Zhou e colaboradores (2008) que avaliaram a presença de enrofloxacino e seu metabólito ciprofloxacino em leite. A simplicidade do método foi capaz de fornecer uma

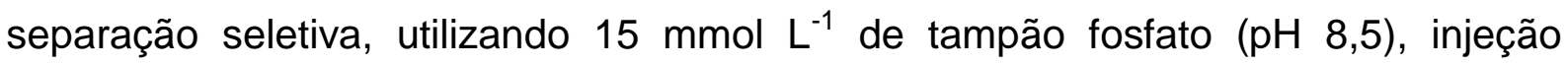
eletrocinética por 20 segundos a +10 kV e separação a +14 kV. 


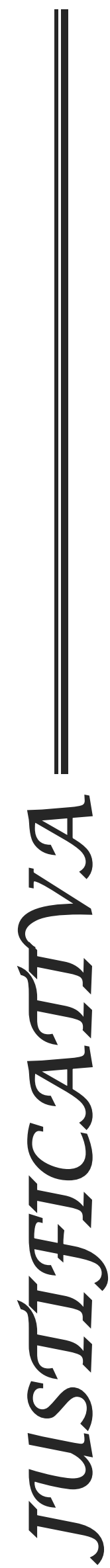




\section{JUSTIFICATIVA}

As fluorquinolonas são fármacos antimicrobianos relativamente recentes, que rapidamente foram aceitos, obtendo amplo emprego clínico.

Apesar de não serem considerados usualmente medicamentos de primeira escolha no tratamento de infecções, são muito conhecidos e estão na lista de medicamentos que são inadequadamente utilizados. Muitas vezes são empregados por pacientes como automedicação. Este fato leva à resistência bacteriana, ocasionada por mutação dos microorganismos e, é a principal causa para a pesquisa e desenvolvimento de inúmeros derivados, visando solucionar o problema da resistência.

O contínuo desenvolvimento de novos antibióticos da mesma classe dificulta as análises de identificação e determinação dos fármacos e produtos de degradação, por suas estruturas químicas possuírem alto nível de semelhança. Um dos pontos mais falhos encontrados nos métodos já existentes é a falta de sensibilidade e especificidade.

Continuamente devem-se realizar as etapas de controle de qualidade de um medicamento buscando-se a continua melhoria e eficácia das preparações farmacêuticas, acompanhando as novas alternativas de técnicas de análises e metodologias que se tornam disponíveis. Este é o caso da EC, que comprovadamente é uma técnica simples, eficaz e de baixo custo em relação a outros métodos e que ao mesmo tempo apresenta alguns atributos da cromatografia e da eletroforese. A CLAE é uma técnica clássica e normalmente empregada no controle de qualidade de medicamentos.

O fármaco que será utilizado nesta pesquisa, o gemifloxacino é de extrema importância devido à indicação clínica, pelo amplo espectro de ação, e utilização em infecções de vias respiratórias.

Pela revisão bibliográfica efetuada, constatou-se que não são muitos os trabalhos em que são descritos e apresentados métodos validados empregando a CZE e CLAE para a análise de fluorquinolonas em medicamentos. Assim sendo, no presente trabalho propõe-se a validação de métodos empregando estas técnicas, para a determinação quantitativa de gemifloxacino, visando a aplicação em análises de rotina para o Controle de Qualidade destes medicamentos. 


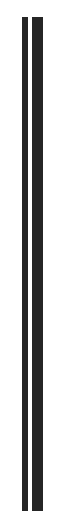

0

0

$\frac{6}{6}$

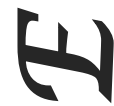

0

1

5

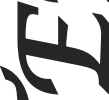

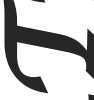

$\theta$

$B$ 


\section{MATERIAL E MÉTODOS}

\subsection{Material}

\subsubsection{Padrões}

Os padrões de trabalho utilizados estão descritos na Tabela 2. O mesilato de gemifloxacino foi cedido pela Aché Laboratórios Farmacêuticos S.A. e o metoprolol foi adquirido na Sigma-Aldrich ${ }^{\circledR}$.

Tabela 2. Padrões utilizados na validação

\begin{tabular}{c|c|c|c|c}
\hline Descrição & Teor & Origem & Lote & Finalidade \\
\hline Mesilato de gemifloxacino & $99,2 \%$ & Aché & QVB8002 & Analito \\
Metoprolol & $99,0 \%$ & Sigma-Aldrich $^{\circledR}$ & $68 \mathrm{H} 0845$ & Padrão interno \\
\hline
\end{tabular}

\subsubsection{Amostras comerciais}

Para a realização do trabalho experimental, utilizaram-se comprimidos revestidos contendo $320 \mathrm{mg}$ de gemifloxacino por comprimido, provenientes da Aché Laboratórios Farmacêuticos SA.

As amostras foram enviadas em embalagens comerciais contendo blisters com cinco comprimidos em cada caixa (Lote $\mathrm{n}^{\circ}$ 0800704B). As amostras foram produzidas em fevereiro de 2008, com validade até fevereiro de 2010.

\subsubsection{Placebo}

O placebo utilizado nas análises, representando o comprimido triturado sem adição de gemifloxacino foi preparado em laboratório com a seguinte composição para $50 \mathrm{~g}$ : 
Celulose microcristalina

$43.7 \mathrm{~g}$

Crospovidona

$1.5 \mathrm{~g}$

Estearato de magnésio.

$0.5 \mathrm{~g}$

Povidona

$2.5 \mathrm{~g}$

Dióxido de titânio

$0.1 \mathrm{~g}$

Hipromelose

$1.5 \mathrm{~g}$

Macrogol.

$0.2 \mathrm{~g}$

\subsubsection{Reagentes e solventes}

Os reagentes e solventes utilizados apresentavam grau de pureza próanálise. Suas finalidades estão apresentados na Tabela 3.

Tabela 3. Reagentes e solventes

\begin{tabular}{|c|c|}
\hline Descrição & Finalidade \\
\hline $\begin{array}{l}\text { Água (purificada através do sistema } \\
\left.\text { Milli- } Q^{\circledR}\right)\end{array}$ & $\begin{array}{l}\text { Preparo de eletrólito, fase móvel, lavagem da } \\
\text { coluna e preparação das soluções }\end{array}$ \\
\hline Ácido clorídrico (Merck ${ }^{\circledR}$ ) & Teste de estresse (validação) \\
\hline Ácido ortofosfórico $\left(\right.$ Merck $^{\circledR}$ ) & Preparo do tampão (CLAE e CZE) \\
\hline Hidróxido de sódio (Merck ${ }^{\circledR}$ ) & $\begin{array}{l}\text { Lavagem do capilar e teste de estresse } \\
\text { (validação) }\end{array}$ \\
\hline Peróxido de hidrogênio (Merck ${ }^{\circledR}$ ) & Teste de estresse (validação) \\
\hline Tetraidrofurano (EM Science $\left.{ }^{\circledR}\right)$ & Preparo da fase móvel (CLAE) \\
\hline Trietilamina $\left(\right.$ Merck $\left.^{\circledR}\right)$ & Preparo da fase móvel (CLAE) \\
\hline $\begin{array}{l}\text { Tetraborato de sódio (Sigma - } \\
\text { Aldrich }^{\circledR} \text { ) }\end{array}$ & Preparo do eletrólito (CZE) \\
\hline
\end{tabular}




\subsubsection{Aparelhos e equipamentos}

As metodologias analíticas foram desenvolvidas e validadas nas instalações do Laboratório de Controle Físico e Químico de Qualidade de Medicamentos e Cosméticos da Faculdade de Ciências Farmacêuticas da Universidade de São Paulo.

- Sistema de cromatografia líquida de alta eficiência, composto por "software" controlador LC Wokstation Class-VP (Shimadzu Corporation, Japão); controlador de sistema modelo SCL-10Avp (Shimadzu Corporation, Japão); degaseificador on line modelo DGU-14A (Shimadzu Corporation, Japão); sistema de bombeamento de solvente modelo LC-10Advp (Shimadzu Corporation, Japão); injetor automático com loop de 50 $\mu \mathrm{L}$ modelo SIL-10 AD vp (Shimadzu Corporation, Japão); forno para controlar temperatura da coluna modelo CTO-10AC vp (Shimadzu Corporation, Japão); detector UV-VIS do tipo DAD (diode array detctor) modelo SPD-M10Avp (Shimadzu Corporation, Japão);

- Fase estacionária LiChrosorb ${ }^{\circledR}$ RP 8 e 100 x 4mm, 5um Merck ${ }^{\circledR}$ (Darmstadt, Germany);

- Sistema de eletroforese capilar Beckman Coulter $M D Q^{\circledR}$ com detector de arranjo de diodos e detector UV/VIS e termostatização de amostras (Part. 285400 Beckman Coulter $^{\circledR}$;

- Capilar de sílica fundida com $40.2 \mathrm{~cm}$ (30 cm efetivo) x $75 \mu \mathrm{m}$ d.i. x $375 \mu \mathrm{m}$ d.e. Beckman Coulter $\mathrm{MDQ}^{\circledR}$;

- Espectrofotômetro Shimatzu ${ }^{\circledR}$, modelo UV-1601, equipado de cubetas de quartzo de $1 \mathrm{~cm}$ de caminho óptico e acoplado a um computador;

- Aparelho de ultra-som, Thornton ${ }^{\circledR}$, modelo T-14;

- Aparelho MiliQ-Plus ${ }^{\circledR}$, Millipore para obtenção da água purificada;

- Balança analítica AB204 Mettler Toledo;

- Banho-maria ETICA;

- Medidor de pH Digimed $^{\circledR}$, modelo TE-91;

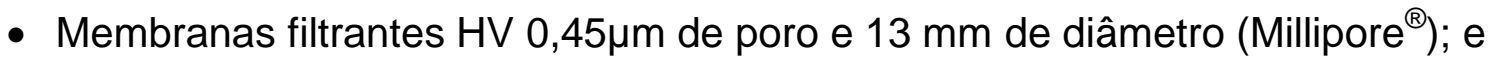




\subsection{Métodos}

\subsubsection{Determinação do comprimento de onda}

Com o objetivo de se obter um espectro de absorção, para determinação da faixa de comprimento de onda $(\lambda)$ a ser testada por CLAE e EC, utilizou-se o água como o "branco" nas duas cubetas de quartzo de $1 \mathrm{~cm}$ de caminho óptico, zerandose assim o equipamento.

Em uma das cubetas trocou-se a água por uma solução de gemifloxacino na concentração de $100,0 \mathrm{ng} \mathrm{mL}^{-1}$ preparado em água purificada. A leitura foi realizada contra o branco na faixa de 200 a $320 \mathrm{~nm}$ com uma velocidade de $370 \mathrm{~nm} \mathrm{~min}{ }^{-1}$.

\subsubsection{Análise cromatográfica}

\subsubsection{Desenvolvimento}

Para ensaios preliminares na CLAE em fase reversa utilizou-se coluna C8 e solução de gemifloxacino na concentração de $200,0 \mu \mathrm{g} \mathrm{mL}^{-1}$ preparada em água purificada. Assim sendo, uma série de experimentos iniciais foi realizada com o intuito de se definir as condições analíticas ideais para a validação do método utilizando informações obtidas na revisão bibliográfica.

$\mathrm{Na}$ primeira etapa do desenvolvimento do método foram investigadas: natureza do modificador orgânico, tampão utilizado na fase aquosa, proporção das duas fases realizando-se os ajustes conforme o decorrer das injeções, em sistema de duas bombas, conforme Tabela 4.

A definição de melhores condições analíticas foi baseada na simplicidade do preparo instrumental, da fase móvel e na avaliação dos cromatogramas através do tempo de retenção, fator de retenção, assimetria do pico e número médio de pratos teóricos. 
Tabela 4. Ensaios realizados no desenvolvimento de metodologia por CLAE

\begin{tabular}{|c|c|c|c|c|c|c|c|c|}
\hline \multirow{2}{*}{ Ensaio } & \multirow{2}{*}{ Coluna } & \multirow{2}{*}{$\begin{array}{l}\text { Detecção } \\
\text { (UV nm) }\end{array}$} & \multicolumn{2}{|c|}{ Fase Móvel } & \multirow{2}{*}{$\mathrm{pH}$} & \multirow{2}{*}{$\begin{array}{c}\text { Vazão } \\
\text { (mL/min) }\end{array}$} & \multirow{2}{*}{$\begin{array}{c}\text { Volume } \\
\text { injeção }(\mu L)\end{array}$} & \multirow{2}{*}{$\begin{array}{c}\text { Temperatura } \\
\left({ }^{\circ} \mathrm{C}\right)\end{array}$} \\
\hline & & & Fase orgânica & Fase aquosa & & & & \\
\hline 1 & $\begin{array}{l}\text { LiChrosorb }^{\circledR} \text { RP } 8 \mathrm{e}(100 x \\
\text { 4mm } 5 \mu \mathrm{m} \text { Merck }^{\circledR}\end{array}$ & $263 ; 254$ e 280 & $40 \%$ de $\mathrm{MeCN}$ & $60 \%$ de $\mathrm{H}_{2} \mathrm{O}$ & 3,0 & 1,0 & 20 & 25 \\
\hline 2 & $\begin{array}{l}\text { LiChrosorb }^{\circledR} \mathrm{RP} 8 \mathrm{e}(100 \mathrm{x} \\
\text { 4mm) } 5 \mu \mathrm{m} \text { Merck }^{\circledR}\end{array}$ & $263 ; 254$ e 280 & $20 \%$ de $\mathrm{MeCN}$ & $80 \%$ de $\mathrm{H}_{2} \mathrm{O}$ & 3,0 & 1,0 & 20 & 25 \\
\hline 3 & $\begin{array}{l}\text { LiChrosorb }^{\circledR} \text { RP } 8 \mathrm{e}(100 x \\
\text { 4mm) } 5 \mu \mathrm{m} \text { Merck }^{\circledR}\end{array}$ & $263 ; 254$ e 280 & $80 \%$ de $\mathrm{MeCN}$ & $20 \%$ de $\mathrm{H}_{2} \mathrm{O}$ & 3,0 & 1,0 & 20 & 25 \\
\hline 4 & $\begin{array}{l}\text { LiChrosorb }^{\circledR} \mathrm{RP} 8 \mathrm{e}(100 \mathrm{x} \\
\text { 4mm) } 5 \mu \mathrm{m} \text { Merck }^{\circledR}\end{array}$ & $263 ; 254$ e 280 & $50 \%$ de $\mathrm{MeCN}$ & $50 \%$ de $\mathrm{H}_{2} \mathrm{O}$ & 3,0 & 1,0 & 20 & 25 \\
\hline 5 & $\begin{array}{l}\text { LiChrosorb }^{\circledR} \text { RP } 8 \mathrm{e}(100 x \\
\text { 4mm } 5 \mu \mathrm{m} \text { Merck }^{\circledR}\end{array}$ & $263 ; 254$ e 280 & $20 \%$ de $\mathrm{MeCN}$ & $80 \%$ de $\mathrm{H}_{2} \mathrm{O}(0,5 \%$ TEA $)$ & 3,0 & 0,4 & 10 & 25 \\
\hline 6 & $\begin{array}{l}\text { LiChrosorb }^{\circledR} \text { RP } 8 e(100 x \\
\text { 4mm } 5 \mu m \text { Merck }^{\circledR}\end{array}$ & $263 ; 254$ e 280 & $20 \%$ de $\mathrm{MeCN}$ & $80 \%$ de $\mathrm{H}_{2} \mathrm{O}(0,5 \%$ TEA $)$ & 3,0 & 1,0 & 10 & 25 \\
\hline 7 & $\begin{array}{l}\text { LiChrosorb }^{\circledR} \mathrm{RP} 8 \mathrm{e}(100 \mathrm{x} \\
\text { 4mm) } 5 \mu \mathrm{m} \text { Merck }^{\circledR}\end{array}$ & $263 ; 254$ e 280 & $30 \%$ de $\mathrm{MeCN}$ & $70 \%$ de $\mathrm{H}_{2} \mathrm{O}(0,5 \%$ TEA $)$ & 3,0 & 1,0 & 10 & 25 \\
\hline 8 & $\begin{array}{l}\text { LiChrosorb }^{\circledR} \mathrm{RP} 8 \mathrm{e}(100 \mathrm{x} \\
\text { 4mm) } 5 \mu \mathrm{m} \text { Merck }^{\circledR}\end{array}$ & $263 ; 254$ e 280 & $25 \%$ de $\mathrm{MeCN}$ & $75 \%$ de $\mathrm{H}_{2} \mathrm{O}(0,5 \%$ TEA $)$ & 3,0 & 1,0 & 10 & 25 \\
\hline 9 & $\begin{array}{l}\text { LiChrosorb }^{\circledR} \text { RP } 8 \mathrm{e}(100 x \\
\text { 4mm) } 5 \mu \mathrm{m} \text { Merck }^{\circledR}\end{array}$ & $263 ; 254$ e 280 & $25 \%$ de $\mathrm{MeOH}$ & $75 \%$ de $\mathrm{H}_{2} \mathrm{O}(0,5 \%$ TEA $)$ & 3,0 & 1,0 & 10 & 25 \\
\hline 10 & $\begin{array}{c}\text { LiChrosorb }^{\circledR} \mathrm{RP} 8 \mathrm{e}(100 \mathrm{x} \\
4 \mathrm{~mm}) 5 \mu \mathrm{m} \text { Merck }^{\circledR}\end{array}$ & $263 ; 254$ e 280 & $20 \%$ de $\mathrm{MeOH}$ & $80 \%$ de $\mathrm{H}_{2} \mathrm{O}(0,5 \%$ TEA $)$ & 3,0 & 1,0 & 10 & 25 \\
\hline
\end{tabular}




\begin{tabular}{|c|c|c|c|c|c|c|c|c|}
\hline 11 & $\begin{array}{l}\text { LiChrosorb }^{\circledR} \mathrm{RP} 8 \mathrm{e}(100 \mathrm{x} \\
4 \mathrm{~mm}) 5 \mu \mathrm{m} \text { Merck }^{\circledR}\end{array}$ & $263 ; 254$ e 280 & $25 \%$ de $\mathrm{MeOH}$ & $75 \%$ de TFA $10 \mathrm{mmol} \mathrm{L}^{-1}$ & 3,0 & 1,0 & 10 & 25 \\
\hline 12 & $\begin{array}{l}\text { LiChrosorb }^{\circledR} \mathrm{RP} 8 \mathrm{e}(100 \mathrm{x} \\
\text { 4mm) } 5 \mu \mathrm{m} \text { Merck }^{\circledR}\end{array}$ & $263 ; 254$ e 280 & $30 \%$ de $\mathrm{MeOH}$ & $70 \%$ de TFA $10 \mathrm{mmol} \mathrm{L}^{-1}$ & 3,0 & 1,0 & 10 & 25 \\
\hline 13 & $\begin{array}{l}\text { LiChrosorb }^{\circledR} \mathrm{RP} 8 \mathrm{e}(100 \mathrm{x} \\
\text { 4mm) } 5 \mu \mathrm{m} \text { Merck }^{\circledR}\end{array}$ & $263 ; 254$ e 280 & $50 \%$ de $\mathrm{MeOH}$ & $50 \%$ de TFA $10 \mathrm{mmol} \mathrm{L}^{-1}$ & 3,0 & 1,0 & 10 & 25 \\
\hline 14 & $\begin{array}{l}\text { LiChrosorb }^{\circledR} \text { RP 8e }(100 x \\
\text { 4mm) } 5 \mu \mathrm{m} \text { Merck }^{\circledR}\end{array}$ & $263 ; 254$ e 280 & $25 \%$ de $\mathrm{MeOH}$ & $\begin{array}{l}75 \% \text { de Acetato de } \\
\text { amônio } 10 \mathrm{mmol} \mathrm{L}^{-1}\end{array}$ & 3,0 & 1,0 & 10 & 25 \\
\hline 15 & $\begin{array}{l}\text { LiChrosorb }^{\circledR} \mathrm{RP} 8 \mathrm{e}(100 \mathrm{x} \\
\quad 4 \mathrm{~mm}) 5 \mu \mathrm{m} \text { Merck }^{\circledR}\end{array}$ & $263 ; 254$ e 280 & $30 \%$ de $\mathrm{MeOH}$ & $\begin{array}{l}70 \% \text { de Acetato de } \\
\text { amônio } 10 \mathrm{mmol} \mathrm{L}^{-1}\end{array}$ & 2,5 & 1,0 & 10 & 25 \\
\hline 16 & $\begin{array}{l}\text { LiChrosorb }^{\circledR} \mathrm{RP} 8 \mathrm{e}(100 \mathrm{x} \\
4 \mathrm{~mm}) 5 \mu \mathrm{m} \text { Merck }^{\circledR}\end{array}$ & $263 ; 254$ e 280 & $40 \%$ de THF & $60 \%$ de $\mathrm{H}_{2} \mathrm{O}(0,5 \%$ TEA $)$ & 3,0 & 1,0 & 10 & 25 \\
\hline 17 & $\begin{array}{l}\text { LiChrosorb }^{\circledR} \text { RP 8e }(100 x \\
\text { 4mm) } 5 \mu \mathrm{m} \text { Merck }^{\circledR}\end{array}$ & $263 ; 254$ e 280 & $20 \%$ de THF & $80 \%$ de $\mathrm{H}_{2} \mathrm{O}(0,5 \%$ TEA $)$ & 3,0 & 1,0 & 10 & 25 \\
\hline 18 & $\begin{array}{l}\text { LiChrosorb }^{\circledR} \mathrm{RP} 8 \mathrm{e}(100 \mathrm{x} \\
\text { 4mm) } 5 \mu \mathrm{m} \text { Merck }^{\circledR}\end{array}$ & 280 & $20 \%$ de THF & $80 \%$ de $\mathrm{H}_{2} \mathrm{O}(0,5 \%$ TEA $)$ & 2,0 & 1,0 & 10 & 25 \\
\hline 19 & $\begin{array}{l}\text { LiChrosorb }^{\circledR} \mathrm{RP} 8 \mathrm{e}(100 \mathrm{x} \\
\text { 4mm) } 5 \mu \mathrm{m} \text { Merck }^{\circledR}\end{array}$ & 280 & $20 \%$ de THF & $\begin{array}{c}80 \% \text { de } \mathrm{H}_{2} \mathrm{O}(0,5 \% \\
\text { DIMEA })\end{array}$ & 3,0 & 1,0 & 10 & 25 \\
\hline 20 & $\begin{array}{l}\text { LiChrosorb }^{\circledR} \mathrm{RP} 8 \mathrm{e}(100 \mathrm{x} \\
\quad 4 \mathrm{~mm}) 5 \mu \mathrm{m} \text { Merck }^{\circledR}\end{array}$ & 280 & $20 \%$ de THF & $80 \%$ de $\mathrm{H}_{2} \mathrm{O}(0,5 \%$ TEA $)$ & 3,0 & 1,0 & 10 & 25 \\
\hline 21 & $\begin{array}{l}\text { LiChrosorb }^{\circledR} \text { RP } 8 e(100 x \\
\text { 4mm) } 5 \mu \mathrm{m} \text { Merck }{ }^{\circledR}\end{array}$ & 280 & $30 \%$ de THF & $70 \%$ de $\mathrm{H}_{2} \mathrm{O}(0,5 \%$ TEA $)$ & 3,0 & 1,0 & 10 & 25 \\
\hline 22 & $\begin{array}{c}\text { LiChrosorb }^{\circledR} \mathrm{RP} 8 \mathrm{e}(100 \mathrm{x} \\
4 \mathrm{~mm}) 5 \mu \mathrm{m} \text { Merck }^{\circledR}\end{array}$ & 280 & $25 \%$ de THF & $75 \%$ de $\mathrm{H}_{2} \mathrm{O}(0,5 \%$ TEA $)$ & 3,0 & 1,0 & 10 & 25 \\
\hline
\end{tabular}




\subsubsection{Condições analíticas}

Após o desenvolvimento da metodologia ficaram definidas as condições cromatográficas para a análise por CLAE:

$\checkmark$ Coluna: LiChrospher ${ }^{\circledR} 100 \mathrm{RP}-8 \mathrm{e}, 5 \mu \mathrm{m}(125 \times 4 \mathrm{~mm}) ;$

$\checkmark$ Fase móvel: THF: solução de trietilamina $0,5 \%$ (pH ajustado para 3,0 com ácido ortofosfórico $\left.0.1 \mathrm{~mol} \mathrm{~L}^{-1}\right)$ na proporção $25: 75(\mathrm{v} / \mathrm{v})$;

$\checkmark$ Vazão: $1,0 \mathrm{~mL} \mathrm{~min}{ }^{-1}$;

$\checkmark$ Volume de injeção: $20 \mu \mathrm{L}$;

$\checkmark$ Comprimento de onda para leitura: $280 \mathrm{~nm}$;

$\checkmark$ Temperatura: $24^{\circ} \mathrm{C} \pm 1^{\circ} \mathrm{C}$;

$\checkmark$ Equipamento: Cromatógrafo à líquido de alta eficiência;

$\checkmark$ Detecção: UV-vis.

\subsection{Preparo da fase móvel}

O método foi desenvolvido utilizando-se o sistema de duas bombas, sendo assim efetuada a mistura automática do tampão e do solvente para fase móvel. O método foi programado para funcionar na proporção 75:25 (v/v).

Em um balão volumétrico de $200 \mathrm{~mL}$ foi adicionado $1.0 \mathrm{~mL}$ de trietilamina concentrada. Completou-se o volume do balão com água purificada e homogenizouse a solução. Com o auxílio do pHmetro, acertou-se o valor do $\mathrm{pH}$ para 3,0 pela

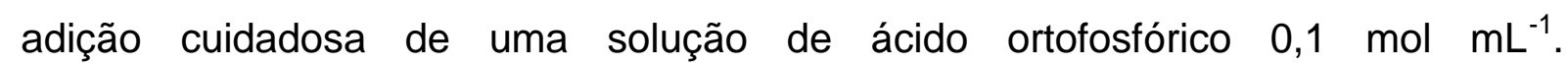
Degaseificou-se a mistura e colocou-se em uma das bombas. Na segunda bomba colocou-se $200 \mathrm{~mL}$ de tetraidrofurano também degaseificado.

\subsubsection{Validação}

A validação do método foi realizada juntamente com a validação por CZE, com as mesmas condições de preparo de soluções descritos no item 5.2.4, com exceção do uso de PI. Os parâmetros utilizados estão descritos no item 5.2.5. 


\subsubsection{Análise eletroforética}

\subsubsection{Desenvolvimento}

Para a realização dos testes iniciais foram utilizados alguns parâmetros médios, como voltagem de $+20 \mathrm{kV}$, temperatura de $22^{\circ} \mathrm{C}$ e introdução da amostra hidrodinâmica a 0,5 psi por $5 \mathrm{~s}$. O capilar utilizado foi de $40,2 \mathrm{~cm}$ de comprimento total num detector de arranjo diodos/ UV-vis. Para tais testes, foi utilizada uma solução de gemifloxacino $300,0 \mu \mathrm{g} \mathrm{mL}^{-1}$.

Inicialmente foram avaliados diferentes tampões: tetraborato de sódio (TBS) e fosfato de sódio em diferentes concentrações. Em seguida foi testado o comportamento do pico de gemifloxacino frente a utilização de solventes orgânicos (etanol e metanol) e também de aditivos (dodecilsulfato de sódio (SDS), Brij ${ }^{\circledR}$ e acetato de amônio). Com a definição do eletrólito, o próximo passo foi a definição do pH ótimo.

Posteriormente à definição do eletrólito, foram otimizadas as condições instrumentais: temperatura na faixa de 18 a $26^{\circ} \mathrm{C}$; voltagem de +15 a $25 \mathrm{kV}$, tempo de aplicação da voltagem, e parâmetros da introdução hidrodinâmica da amostra (pressão e tempo). Para finalizar o desenvolvimento definiu-se a preparação e lavagem do capilar antes de cada introdução de amostra.

A escolha das condições instrumentais adequada foi baseada na avaliação de diversos ensaios apresentados na Tabela 5. Estes ensaios foram sendo realizados conforme os resultados foram se aproximando do esperado. 
Tabela 5. Ensaios realizados no desenvolvimento de metodologia por CZE

\begin{tabular}{|c|c|c|c|c|c|c|c|}
\hline Ensaio & Coluna & $\begin{array}{l}\text { Detecção } \\
\text { (UV nm) }\end{array}$ & Eletrólito & $\mathrm{pH}$ & $\begin{array}{c}\text { Injeção } \\
\text { (hidrodinâmica) }\end{array}$ & $\begin{array}{l}\stackrel{+}{\text { Voltagem }} \\
\quad(\mathrm{kV})\end{array}$ & $\begin{array}{c}\text { Temperatura } \\
\left({ }^{\circ} \mathrm{C}\right)\end{array}$ \\
\hline 1 & $\begin{array}{l}\text { Sílica fundida: } 40.2 \mathrm{~cm} \text { de } \\
\text { comprimento, } 30 \mathrm{~cm} \text { efetivos } \\
\text { e } 75 \mu \mathrm{m} \text { de diâmetro interno. }\end{array}$ & $\begin{array}{l}263 ; 254 \text { e } \\
280\end{array}$ & TBS $10 \mathrm{mmol} \mathrm{L}-1$ & 8,9 & $0,5 \mathrm{psi} ; 5 \mathrm{~s}$ & 18 & 22 \\
\hline 2 & $\begin{array}{l}\text { Sílica fundida: } 40.2 \mathrm{~cm} \text { de } \\
\text { comprimento, } 30 \mathrm{~cm} \text { efetivos } \\
\text { e } 75 \mu \mathrm{m} \text { de diâmetro interno. }\end{array}$ & $\begin{array}{l}263 ; 254 \text { e } \\
280\end{array}$ & $\begin{array}{l}\text { Tampão fosfato de sódio } \\
40 \mathrm{mmol} \mathrm{L-1}\end{array}$ & 8,9 & $0,5 \mathrm{psi} ; 5 \mathrm{~s}$ & 18 & 22 \\
\hline 3 & $\begin{array}{l}\text { Sílica fundida: } 40.2 \mathrm{~cm} \text { de } \\
\text { comprimento, } 30 \mathrm{~cm} \text { efetivos } \\
\text { e } 75 \mu \mathrm{m} \text { de diâmetro interno. }\end{array}$ & $\begin{array}{l}263 ; 254 \text { e } \\
280\end{array}$ & TBS $10 \mathrm{mmol} \mathrm{L}-1$ & 8,9 & $0,5 \mathrm{psi} ; 5 \mathrm{~s}$ & 18 & 22 \\
\hline 4 & $\begin{array}{l}\text { Sílica fundida: } 40.2 \mathrm{~cm} \text { de } \\
\text { comprimento, } 30 \mathrm{~cm} \text { efetivos } \\
\text { e } 75 \mu \mathrm{m} \text { de diâmetro interno. }\end{array}$ & $\begin{array}{l}263 ; 254 \text { e } \\
280\end{array}$ & TBS $20 \mathrm{mmol}$ L-1 & 8,9 & $0,5 \mathrm{psi} ; 5 \mathrm{~s}$ & 18 & 22 \\
\hline 5 & $\begin{array}{l}\text { Sílica fundida: } 40.2 \mathrm{~cm} \text { de } \\
\text { comprimento, } 30 \mathrm{~cm} \text { efetivos } \\
\text { e } 75 \mu \mathrm{m} \text { de diâmetro interno. }\end{array}$ & $\begin{array}{l}263 ; 254 \text { e } \\
\quad 280\end{array}$ & TBS 30 mmol L-1 & 8,9 & $0,5 \mathrm{psi} ; 5 \mathrm{~s}$ & 18 & 22 \\
\hline 6 & $\begin{array}{l}\text { Sílica fundida: } 40.2 \mathrm{~cm} \text { de } \\
\text { comprimento, } 30 \mathrm{~cm} \text { efetivos } \\
\text { e } 75 \mu \mathrm{m} \text { de diâmetro interno. }\end{array}$ & $\begin{array}{l}263 ; 254 \text { e } \\
\quad 280\end{array}$ & TBS $40 \mathrm{mmol}$ L-1 & 8,9 & $0,5 \mathrm{psi} ; 5 \mathrm{~s}$ & 18 & 22 \\
\hline 7 & $\begin{array}{l}\text { Sílica fundida: } 40.2 \mathrm{~cm} \text { de } \\
\text { comprimento, } 30 \mathrm{~cm} \text { efetivos } \\
\text { e } 75 \mu \mathrm{m} \text { de diâmetro interno. }\end{array}$ & $\begin{array}{l}263 ; 254 \text { e } \\
280\end{array}$ & $\begin{array}{l}\text { TBS } 40 \mathrm{mmol} \mathrm{L}-1 \\
\text { Brij } 5 \mathrm{mmol} \mathrm{L-1}\end{array}$ & 8,9 & 0,5 psi; $3 \mathrm{~s}$ & 18 & 22 \\
\hline 8 & $\begin{array}{l}\text { Sílica fundida: } 40.2 \mathrm{~cm} \text { de } \\
\text { comprimento, } 30 \mathrm{~cm} \text { efetivos } \\
\text { e } 75 \mu \mathrm{m} \text { de diâmetro interno. }\end{array}$ & $\begin{array}{l}263 ; 254 \text { e } \\
280\end{array}$ & $\begin{array}{l}\text { TBS } 40 \text { mmol L-1, } \\
\text { Brij } 15 \mathrm{mmol} \mathrm{L-1}\end{array}$ & 8,9 & 0,5 psi; $3 \mathrm{~s}$ & 18 & 22 \\
\hline
\end{tabular}


Sílica fundida: $40.2 \mathrm{~cm}$ de

9 comprimento, $30 \mathrm{~cm}$ efetivos e 75 m de diâmetro interno.

Sílica fundida: $40.2 \mathrm{~cm}$ de comprimento, $30 \mathrm{~cm}$ efetivos e $75 \mu \mathrm{m}$ de diâmetro interno.

Sílica fundida: $40.2 \mathrm{~cm}$ de comprimento, $30 \mathrm{~cm}$ efetivos e $75 \mu \mathrm{m}$ de diâmetro interno.

Sílica fundida: $40.2 \mathrm{~cm}$ de comprimento, $30 \mathrm{~cm}$ efetivos e $75 \mu \mathrm{m}$ de diâmetro interno.

Sílica fundida: $40.2 \mathrm{~cm}$ de comprimento, $30 \mathrm{~cm}$ efetivos e $75 \mu \mathrm{m}$ de diâmetro interno.

Sílica fundida: $40.2 \mathrm{~cm}$ de

14 comprimento, $30 \mathrm{~cm}$ efetivos e $75 \mu \mathrm{m}$ de diâmetro interno.

Sílica fundida: $40.2 \mathrm{~cm}$ de comprimento, $30 \mathrm{~cm}$ efetivos e 75 um de diâmetro interno.

Sílica fundida: $40.2 \mathrm{~cm}$ de comprimento, $30 \mathrm{~cm}$ efetivos e 75 um de diâmetro interno.

Sílica fundida: $40.2 \mathrm{~cm}$ de

17 comprimento, $30 \mathrm{~cm}$ efetivos e 75 um de diâmetro interno.

Sílica fundida: $40.2 \mathrm{~cm}$ de e 75 m de diâmetro interno.

263; 254 e 280

263; 254 e 280

263; 254 e 280

263; 254 e 280

263; 254 e 280

263; 254 e 280

263; 254 e 280

263; 254 e 280

263; 254 e 280

263; 254 e 280
TBS $40 \mathrm{mmol} \mathrm{L-1}$ Brij $20 \mathrm{mmol} \mathrm{L-1}$

TBS 40 mmol L-1

4,0

0,5 psi; $3 \mathrm{~s}$

18

22

TBS $40 \mathrm{mmol} \mathrm{L}-1$, $\mathrm{NH} 4 \mathrm{Ac} 10 \mathrm{mmol} \mathrm{L}-1$

$9,0 \quad 0,5 \mathrm{psi} ; 3 \mathrm{~s}$

18

22

TBS $40 \mathrm{mmol} \mathrm{L}-1$, $0,2 \%$ TEA

$9,0 \quad 0,5 \mathrm{psi} ; 3 \mathrm{~s}$

18

22

TBS 40 mmol L-1

8,9

0,5 psi; $3 \mathrm{~s}$

18

18

TBS $40 \mathrm{mmol} \mathrm{L-1}$

8,9

0,5 psi; $3 \mathrm{~s}$

20

TBS 40 mmol L-1

8,9 $\quad 0,5 \mathrm{psi} ; 3 \mathrm{~s}$

22

TBS 40 mmol L-1

8,9 0,5 psi; $3 \mathrm{~s}$

24

18

TBS 40 mmol L-1

8,9

0,5 psi; $3 \mathrm{~s}$

18

20

TBS $40 \mathrm{mmol} \mathrm{L-1}$

8,9

0,5 psi; 3 s

20

20 
Sílica fundida: $40.2 \mathrm{~cm}$ de comprimento, $30 \mathrm{~cm}$ efetivos e 75 m de diâmetro interno.

Sílica fundida: $40.2 \mathrm{~cm}$ de

\section{0} comprimento, $30 \mathrm{~cm}$ efetivos e $75 \mu \mathrm{m}$ de diâmetro interno.

Sílica fundida: $40.2 \mathrm{~cm}$ de comprimento, $30 \mathrm{~cm}$ efetivos e $75 \mu \mathrm{m}$ de diâmetro interno.

Sílica fundida: $40.2 \mathrm{~cm}$ de comprimento, $30 \mathrm{~cm}$ efetivos e $75 \mu \mathrm{m}$ de diâmetro interno.

Sílica fundida: $40.2 \mathrm{~cm}$ de comprimento, $30 \mathrm{~cm}$ efetivos e $75 \mu \mathrm{m}$ de diâmetro interno.

Sílica fundida: $40.2 \mathrm{~cm}$ de 24 comprimento, $30 \mathrm{~cm}$ efetivos e 75 um de diâmetro interno.

Sílica fundida: $40.2 \mathrm{~cm}$ de 25 comprimento, $30 \mathrm{~cm}$ efetivos e $75 \mu \mathrm{m}$ de diâmetro interno.

Sílica fundida: $40.2 \mathrm{~cm}$ de comprimento, $30 \mathrm{~cm}$ efetivos e $75 \mu \mathrm{m}$ de diâmetro interno.

Sílica fundida: $40.2 \mathrm{~cm}$ de

27 comprimento, $30 \mathrm{~cm}$ efetivos e 75 um de diâmetro interno.

Sílica fundida: $40.2 \mathrm{~cm}$ de comprimento, $30 \mathrm{~cm}$ efetivos e 75 um de diâmetro interno.
263; 254 e 280

263; 254 e 280

263; 254 e 280

263; 254 e 280

263; 254 e 280

$263 ; 254$ e 280

263; 254 e 280

263; 254 e 280

263; 254 e 280

263; 254 e 280
TBS $40 \mathrm{mmol} \mathrm{L-1}$

8,9

0,5 psi; 3 s

22

20

TBS $40 \mathrm{mmol} \mathrm{L-1} \quad 8,9 \quad 0,5 \mathrm{psi} ; 3 \mathrm{~s}$

18

22

TBS $40 \mathrm{mmol} \mathrm{L-1} \quad 8,9 \quad 0,5 \mathrm{psi} ; 3 \mathrm{~s}$

20

22

TBS $40 \mathrm{mmol} \mathrm{L-1} \quad 8,9 \quad 0,5 \mathrm{psi} ; 3 \mathrm{~s}$

22

22

TBS $40 \mathrm{mmol} \mathrm{L-1} \quad 8,9 \quad 0,5 \mathrm{psi}$; $3 \mathrm{~s}$

18

TBS $40 \mathrm{mmol} \mathrm{L-1} \quad 8,9 \quad 0,5 \mathrm{psi} ; 3 \mathrm{~s}$

TBS 40 mmol L-1

8,9 0,5 psi; $3 \mathrm{~s}$

18

TBS 45 mmol L-1

8,9 0,5 psi; $3 \mathrm{~s}$

18

18

TBS $50 \mathrm{mmol} \mathrm{L-1}$

8,9

0,5 psi; $3 \mathrm{~s}$

18

18

TBS 55 mmol L-1

8,9 $\quad 0,5$ psi; $3 \mathrm{~s}$

18

18 
Sílica fundida: $40.2 \mathrm{~cm}$ de comprimento, $30 \mathrm{~cm}$ efetivos e 75 m de diâmetro interno.

Sílica fundida: $40.2 \mathrm{~cm}$ de comprimento, $30 \mathrm{~cm}$ efetivos e $75 \mu \mathrm{m}$ de diâmetro interno.

Sílica fundida: $40.2 \mathrm{~cm}$ de comprimento, $30 \mathrm{~cm}$ efetivos e $75 \mu \mathrm{m}$ de diâmetro interno.

Sílica fundida: $40.2 \mathrm{~cm}$ de comprimento, $30 \mathrm{~cm}$ efetivos e $75 \mu \mathrm{m}$ de diâmetro interno. comprimento, $30 \mathrm{~cm}$ efetivos e $75 \mu \mathrm{m}$ de diâmetro interno.

263; 254 e 280

263; 254 e 280

$263 ; 254$ e
280

263; 254 e 280

263; 254 e 280

Sílica fundida: $40.2 \mathrm{~cm}$ de 34 comprimento, $30 \mathrm{~cm}$ efetivos e $75 \mu \mathrm{m}$ de diâmetro interno.

Sílica fundida: $40.2 \mathrm{~cm}$ de comprimento, $30 \mathrm{~cm}$ efetivos e $75 \mu \mathrm{m}$ de diâmetro interno.

Sílica fundida: $40.2 \mathrm{~cm}$ de comprimento, $30 \mathrm{~cm}$ efetivos e $75 \mu \mathrm{m}$ de diâmetro interno.

Sílica fundida: $40.2 \mathrm{~cm}$ de comprimento, $30 \mathrm{~cm}$ efetivos e 75 um de diâmetro interno.

Sílica fundida: $40.2 \mathrm{~cm}$ de 38

263; 254 e 280

263; 254 e

263; 254 e

263; 254 e 280

263; 254 e e $75 \mu \mathrm{m}$ de diâmetro interno.

TBS $60 \mathrm{mmol} \mathrm{L-1}$

8,9

0,5 psi; $3 \mathrm{~s}$

18

18

TBS 50 mmol L-1

8,9 0,3 psi; $3 \mathrm{~s}$

18

18

TBS $50 \mathrm{mmol} \mathrm{L}$

8,9 $\quad 0,3 \mathrm{psi} ; 4 \mathrm{~s}$

18

18

TBS $50 \mathrm{mmol} \mathrm{L}$

8,9 0,3 psi; $5 \mathrm{~s}$

18

18

TBS $50 \mathrm{mmol} \mathrm{L}$

8,9 0,4 psi; $3 \mathrm{~s}$

18

TBS $50 \mathrm{mmol} \mathrm{L}$

8,9 0,4 psi; $4 \mathrm{~s}$

18

TBS $50 \mathrm{mmol} \mathrm{L}$

8,9 0,4 psi; $5 \mathrm{~s}$

18

TBS $50 \mathrm{mmol} \mathrm{L}$

$\begin{array}{lll}8,9 & 0,5 \mathrm{psi} ; 3 \mathrm{~s} & 18\end{array}$

18

TBS $50 \mathrm{mmol} \mathrm{L}$

$8,9 \quad 0,5 \mathrm{psi} ; 4 \mathrm{~s} \quad 18$

18 280

TBS $50 \mathrm{mmol} \mathrm{L}$

$\begin{array}{lll}8,9 & 0,5 \mathrm{psi} ; 5 \mathrm{~s} & 18\end{array}$


Sílica fundida: $40.2 \mathrm{~cm}$ de comprimento, $30 \mathrm{~cm}$ efetivos e 75 m de diâmetro interno.

Sílica fundida: $40.2 \mathrm{~cm}$ de comprimento, $30 \mathrm{~cm}$ efetivos e $75 \mu \mathrm{m}$ de diâmetro interno.

Sílica fundida: $40.2 \mathrm{~cm}$ de comprimento, $30 \mathrm{~cm}$ efetivos e $75 \mu \mathrm{m}$ de diâmetro interno.

Sílica fundida: $40.2 \mathrm{~cm}$ de comprimento, $30 \mathrm{~cm}$ efetivos e $75 \mu \mathrm{m}$ de diâmetro interno.

Sílica fundida: $40.2 \mathrm{~cm}$ de comprimento, $30 \mathrm{~cm}$ efetivos e $75 \mu \mathrm{m}$ de diâmetro interno.

Sílica fundida: $40.2 \mathrm{~cm}$ de

44 comprimento, $30 \mathrm{~cm}$ efetivos e $75 \mu \mathrm{m}$ de diâmetro interno.

Sílica fundida: $40.2 \mathrm{~cm}$ de comprimento, $30 \mathrm{~cm}$ efetivos e $75 \mu \mathrm{m}$ de diâmetro interno.

Sílica fundida: $40.2 \mathrm{~cm}$ de comprimento, $30 \mathrm{~cm}$ efetivos e $75 \mu \mathrm{m}$ de diâmetro interno.

Sílica fundida: $40.2 \mathrm{~cm}$ de

47 comprimento, $30 \mathrm{~cm}$ efetivos e $75 \mu \mathrm{m}$ de diâmetro interno.
263; 254 e 280

263; 254 e 280

263; 254 e 280

$263 ; 254$ e 280

263; 254 e 280

263; 254 e 280

263; 254 e 280

263; 254 e 280

263; 254 e 280
TBS $50 \mathrm{mmol} \mathrm{L}$

$$
\text { 7,0 } \quad 0,5 \text { psi; } 5 \mathrm{~s}
$$

TBS $50 \mathrm{mmol} \mathrm{L}$

$\begin{array}{lll}7,5 & 0,5 \mathrm{psi} ; 5 \mathrm{~s} & 18\end{array}$

TBS $50 \mathrm{mmol} \mathrm{L}$

$\begin{array}{lll}8,0 & 0,5 \mathrm{psi} ; 5 \mathrm{~s} & 18\end{array}$

TBS $50 \mathrm{mmol} \mathrm{L}$

$8,5 \quad 0,5 \mathrm{psi} ; 5 \mathrm{~s} \quad 18$

TBS $50 \mathrm{mmol} \mathrm{L}$

$9,0 \quad 0,5 \mathrm{psi} ; 5 \mathrm{~s} \quad 18$

TBS $50 \mathrm{mmol} \mathrm{L}$

$9,5 \quad 0,5$ psi; $5 \mathrm{~s} \quad 18$

TBS $50 \mathrm{mmol} \mathrm{L}$

$10,0 \quad 0,5 \mathrm{psi} ; 5 \mathrm{~s}$

TBS $50 \mathrm{mmol} \mathrm{L}$

$8,4 \quad 0,5$ psi; $5 \mathrm{~s} \quad 18$

TBS $50 \mathrm{mmol} \mathrm{L}$ 


\subsubsection{Condições analíticas}

$\checkmark$ Capilar: sílica fundida de 40,2 cm de comprimento sendo $30 \mathrm{~cm}$ efetivos, $75 \mu \mathrm{m}$ de d.i. e $375 \mu \mathrm{m}$ de d.e., Beckman Coulter $\mathrm{MDQ}^{\circledR}$;

$\checkmark$ Eletrólito: Tampão tetraborato de sódio $50 \mathrm{mmol} \mathrm{L}^{-1}(\mathrm{pH} 8,6$ corrigido com ácido ortofosfórico);

$\checkmark$ Voltagem: $+20 \mathrm{kV}$;

$\checkmark$ Modo de injeção: hidrodinâmica a 0,5 psi por 5 segundos;

$\checkmark \quad$ Temperatura: $18^{\circ} \mathrm{C}$;

$\checkmark \quad$ Comprimento de onda para leitura: $263 \mathrm{~nm}$;

$\checkmark$ Equipamento: Sistema de eletroforese capilar Beckman Coulter MDQ ${ }^{\circledR}$;

$\checkmark$ Detecção: Arranjo diiodo/ UV-vis;

$\checkmark$ Padrão interno: metoprolol.

\subsection{Tratamento do capilar}

Foi utilizado um capilar novo de sílica fundida de 40,2 cm de comprimento $x$ $75 \mu \mathrm{m}$ de diâmetro interno (d.i.) x $375 \mu \mathrm{m}$ de diâmetro externo (d.e.) com revestimento externo de poliimida. Uma fenda óptica de aproximadamente $0,2 \mathrm{~cm}$ foi preparada através de um rápido aquecimento a fim da remoção da poliimida no local e em seguida realizou-se a limpeza com acetona.

O capilar foi ajustado ao equipamento com o auxilio de um cartucho próprio e fixando a fenda óptica na posição do detector UV para passagem do feixe de luz, o comprimento do tubo até esta posição foi $30 \mathrm{~cm}$.

A ativação deste capilar foi realizada sob temperatura de $25^{\circ} \mathrm{C}$, e foi acondicionado com solução de hidróxido de sódio $(\mathrm{NaOH}) \quad 0,1 \mathrm{~mol} \mathrm{~L}^{-1}$ por 30 minutos, água purificada por 20 minutos e eletrólito de corrida por 20 minutos.

Diariamente realizou-se a lavagem do capilar com solução de $\mathrm{NaOH} \mathrm{0,1} \mathrm{mol}$ $\mathrm{L}^{-1}$ por 10 minutos, água purificada por 5 minutos e eletrólito de corrida por 10 minutos. Entre cada corrida o capilar foi lavado por 1 minuto com $\mathrm{NaOH} 0,1 \mathrm{~mol} \mathrm{~L}^{-1} \mathrm{e}$ 
1 minuto com eletrólito. Ao final do dia, o capilar foi lavado com $\mathrm{NaOH} 0.1 \mathrm{~mol} \mathrm{~L}^{-1}$ por 10 minutos, água purificada por 5 minutos.

\subsection{Preparo do eletrólito}

Semanalmente, uma solução estoque de TBS na concentração de 500,0 $\mathrm{mmol} \mathrm{L}^{-1}$ foi preparada para diluição diária e preparo do eletrólito. Pesou-se uma massa de 19,0685 g e transferiu-se cuidadosamente para um balão de $100 \mathrm{~mL}$, e diluiu-se em água purificada. Colocou-se o balão em banho de ultra-som até total diluição. Em seguida completou-se o volume do balão com água purificada e filtrouse a solução com filtro Millipore ${ }^{\circledR}(0,45 \mu \mathrm{m})$.

A cada ensaio preparou-se a solução de eletrólito a partir da solução estoque de TBS $500 \mathrm{mmol} \mathrm{L}^{-1}$, transferindo-se uma alíquota de $5 \mathrm{~mL}$ para um balão volumétrico de $50 \mathrm{~mL}$. Completou-se o volume do balão com água purificada. Com o auxílio de um pHmêtro ajustou-se o pH para 8,6 através da adição cuidadosa da solução de ácido ortofosfórico $0,1 \mathrm{~mol} \mathrm{~L}^{-1}$. Em seguida filtrou-se a solução com filtro Millipore ${ }^{\circledR}(0,45 \mu \mathrm{m})$ e deaerou-se através de um banho de ultra-som por 10 minutos.

\subsubsection{Validação}

A validação do método por CZE foi realizada mas mesmas condições da validação por CLAE com o preparo de soluções descritas no item 5.2.4, utilizando-se PI e os parâmetros descritos no item 5.2.5.

\subsubsection{Preparo de soluções}

Ao final do desenvolvimento de cada método realizou-se, para cada técnica a avaliação do melhor solvente $\left(\mathrm{MeOH}, \mathrm{MeCN}\right.$, solução $\mathrm{NaOH} 0,01 \mathrm{~mol} \mathrm{~L}^{-1}$ e água purificada) para dissolver amostra e o padrão, com o objetivo de encontrar um solvente que pudesse ser utilizado com ambas as técnicas. Para a validação, as soluções preparadas foram transferidas para frascos protegidos da luz com papel alumínio e armazenadas em geladeira a aproximadamente $4^{\circ} \mathrm{C}$. As soluções foram preparadas diariamente. 


\subsubsection{Solução padrão estoque de gemifloxacino}

Uma massa correspondente a $0,005 \mathrm{~g}$ de mesilato de gemifloxacino foi cuidadosamente pesada, colocada em um balão volumétrico $(10 \mathrm{~mL})$. Dissolveu-se a massa e completou-se o volume do balão com água purificada para a obtenção de uma solução de concentração $500,0 \mu \mathrm{g} \mathrm{mL}^{-1}$.

\subsubsection{Solução padrão estoque de metoprolol}

Uma massa correspondente a $0,05 \mathrm{~g}$ de metoprolol foi cuidadosamente pesada, transferida para um balão volumétrico $(10 \mathrm{~mL})$ e solubilizada em metanol para a obtenção de uma solução de concentração de 5000,0 $\mathrm{\mu g} \mathrm{mL}^{-1}$.

Esta solução foi utilizada como padrão interno apenas para as análises realizadas em CZE.

\subsubsection{Preparo da solução estoque da amostra de gemifloxacino}

Foram pesados separadamente 10 comprimidos de gemifloxacino e calculado o peso médio de $436.71 \mathrm{mg}$. Dentro do peso médio, de acordo com o valor declarado, 320,0 mg são de mesilato de gemifloxacino. Estes comprimidos foram triturados cuidadosamente em um cadinho com pistilo de porcelana.

Para uma solução de $50 \mathrm{~mL}$ contendo $500,0 \mu \mathrm{g} \mathrm{mL}^{-1}$ de gemifloxacino, pesouse $34,12 \mathrm{mg}$ do comprimido triturado, transferiu-se para um balão volumétrico e dissolveu-se com água em banho de ultra-som. Completou-se o volume do balão com água e filtrou-se a solução.

\subsubsection{Preparo da curva analítica}

A solução padrão de gemifloxacino na concentração de $500,0 \mu \mathrm{g} \mathrm{mL}^{-1}$ foi diluída de modo a serem obtidas soluções de diferentes concentrações, que foram utilizadas para a obtenção da curva analítica (Tabela 6). Para a EC, antes de completar os volumes dos balões, para cada nível de concentração foi adicionada a solução de metoprolol utilizada como padrão interno, conforme Tabela 7. 
Tabela 6. Obtenção da curva de calibração para o gemifloxacino

\begin{tabular}{|c|c|c|c|c|}
\hline Nível & $\begin{array}{l}\text { Solução estoque } \\
\qquad\left(\mu \mathrm{gL}^{-1}\right)\end{array}$ & $\begin{array}{c}\text { Volume } \\
\text { pipetado }(\mathrm{mL})\end{array}$ & $\begin{array}{l}\text { Concentração } \\
\text { final }\left(\mu \mathrm{g} \mathrm{m} \mathrm{L}^{-1}\right)\end{array}$ & $\begin{array}{r}\text { Volume } \\
\text { final }(m L)\end{array}$ \\
\hline 1 & 500,0 & 0,35 & 35,0 & 5,0 \\
\hline 2 & 500,0 & 0,40 & 40,0 & 5,0 \\
\hline 3 & 500,0 & 0,45 & 45,0 & 5,0 \\
\hline 4 & 500,0 & 0,50 & 50,0 & 5,0 \\
\hline 5 & 500,0 & 0,55 & 55,0 & 5,0 \\
\hline 6 & 500,0 & 0,60 & 60,0 & 5,0 \\
\hline 7 & 500,0 & 0,65 & 65,0 & 5,0 \\
\hline
\end{tabular}

Tabela 7. Diluição da solução de metoprolol utilizada como padrão interno em EC

\begin{tabular}{cccc}
\hline $\begin{array}{c}\text { Concentração solução estoque de } \\
\mathbf{P I}\left(\mu \mathrm{gL}^{-1}\right)\end{array}$ & $\begin{array}{c}\text { Volume } \\
\text { pipetado }(\mathrm{mL})\end{array}$ & $\begin{array}{c}\text { Concentração final } \\
\text { de PI }\left(\mu \mathrm{gL}^{-1}\right)\end{array}$ & $\begin{array}{c}\text { Volume } \\
\text { Final }(\mathrm{mL})\end{array}$ \\
\hline 5000,0 & 0,5 & 500,0 & 5,0 \\
\hline
\end{tabular}

\subsubsection{Validação dos métodos}

A validação das metodologias desenvolvidas para a determinação quantitativa de gemifloxacino em preparação farmacêutica foi realizada seguindo os principais guias internacionais como ICH e a Farmacopéia Americana, além do guia brasileiro publicado pela ANVISA, conforme item 3.5 da revisão bibliográfica. 


\subsubsection{Seletividade}

\subsection{Pesquisa de interferentes no placebo}

Para garantir a não interferência da matriz da amostra, preparou-se um placebo realizando uma mistura homogênea dos excipientes (item 5.1.3) contidos na amostra comercial.

Da mesma forma foi preparada de uma solução da amostra de gemifloxacino com 50,0 $\mathrm{g} \mathrm{mL}^{-1}$. Para tanto, pesou-se uma massa de $34,12 \mathrm{mg}$ da mistura de excipientes, transferiu-se para um balão de $50 \mathrm{~mL}$, dissolveu-se em água com auxílio do banho de ultra-som e filtrou-se. Transferiu-se uma alíquota de $1 \mathrm{~mL}$ para um balão de $10 \mathrm{~mL}$ e completou-se o volume do balão com água.

\subsection{Teste de estresse}

Este teste foi executado para avaliar a interferência de produtos de degradação e metabólitos na eficiência do pico do gemifloxacino. O teste de estresse foi realizado através de reações de hidrólise da amostra em diferentes meios e a alta temperatura (Tabela 8).

Tabela 8. Condições avaliadas nos testes de estresse

\begin{tabular}{lccl}
\hline Hidrólise & $\begin{array}{c}\text { Aquecimento } \\
\text { banho-maria }\end{array}$ & Tempo (horas) & \multicolumn{1}{c}{ Solvente } \\
\hline Meio neutro & $80^{\circ} \mathrm{C}$ & 2 & Água \\
Meio oxidativo & $80^{\circ} \mathrm{C}$ & 2 & $\mathrm{H}_{2} \mathrm{O}_{2} 3 \%$ \\
Meio ácido & $80^{\circ} \mathrm{C}$ & 2 & $\mathrm{HCl} 0.1 \mathrm{~mol} \mathrm{~L}^{-1}$ \\
Meio alcalino & $80^{\circ} \mathrm{C}$ & 2 & $\mathrm{NaOH} 0.1 \mathrm{~mol} \mathrm{~L}^{-1}$ \\
\hline
\end{tabular}

\subsection{Hidrólise em meio neutro}

Pesou-se uma massa de 0,0125 g de mesilato de gemifloxacino e transferiuse cuidadosamente para um balão volumétrico de $25 \mathrm{~mL}$. Dissolveu-se a massa e completou-se o volume do balão com água purificada para a obtenção de uma 
solução de concentração $500,0 \mu \mathrm{g} \mathrm{m}^{-1}$. Em seguida esta solução foi submetida a uma temperatura de $80^{\circ} \mathrm{C}$.

Nos períodos de 0,15, 30, 60, 90 e 120 minutos foram retiradas alíquotas de $1 \mathrm{~mL}$ e transferidas para um balão de $10 \mathrm{~mL}$, após resfriadas a temperatura ambiente, o volume foi completado com água. Obteve-se uma concentração final de $50,0 \mu \mathrm{g} \mathrm{mL}-1$, completando-se um tempo total de duas horas. A solução final foi injetada em triplicata.

\subsection{Hidrólise em meio oxidativo}

Pesou-se uma massa de 0,0125 g de mesilato de gemifloxacino e transferiuse cuidadosamente para um balão volumétrico de $25 \mathrm{~mL}$. Dissolveu-se a massa e completou-se o volume do balão com peróxido de hidrogênio $\left(\mathrm{H}_{2} \mathrm{O}_{2}\right)$ diluído a $3 \%$ para a obtenção de uma solução de concentração $500,0 \mu \mathrm{g} \mathrm{mL}^{-1}$. Em seguida esta solução foi submetida a uma temperatura de $80^{\circ} \mathrm{C}$.

Nos períodos de 0,15, 30, 60, 90 e 120 minutos foram retiradas alíquotas de $1 \mathrm{~mL}$ e transferidas para um balão de $10 \mathrm{~mL}$, resfriadas a temperatura ambiente e o volume completado com água. Obteve-se uma concentração final de 50,0 $\mu \mathrm{g} \mathrm{mL}^{-1}$, completando-se um tempo total de duas horas. A solução final foi injetada em triplicata.

\subsection{Hidrólise em meio ácido}

Pesou-se uma massa de 0,0125 g de mesilato de gemifloxacino e transferiuse cuidadosamente para um balão volumétrico de $25 \mathrm{~mL}$. Dissolveu-se a massa e completou-se o volume do balão com ácido clorídrico $(\mathrm{HCl}) 0,1 \mathrm{~mol} \mathrm{~L}^{-1}$ para a obtenção de uma solução de concentração $500,0 \mu \mathrm{g} \mathrm{mL}^{-1}$. Em seguida esta solução foi submetida a uma temperatura de $80^{\circ} \mathrm{C}$.

Nos períodos de 0, 15, 30, 60, 90 e 120 minutos foram retiradas alíquotas de $1 \mathrm{~mL}$ e transferidas para um balão de $10 \mathrm{~mL}$ e resfriadas a temperatura ambiente. Neutralizou-se com uma alíquota de $1 \mathrm{~mL}$ de $\mathrm{NaOH} 0,1 \mathrm{~mol} \mathrm{~L}^{-1}$ e o volume foi completado com água. Obteve-se uma concentração final de 50,0 $\mu \mathrm{g} \mathrm{mL} \mathrm{m}^{-1}$, 
completando-se um tempo total de duas horas. A solução final foi injetada em triplicata.

\subsection{Hidrólise em meio alcalino}

Pesou-se uma massa de 0,0125 g de mesilato de gemifloxacino e transferiuse cuidadosamente para um balão volumétrico de $25 \mathrm{~mL}$. Dissolveu-se a massa e

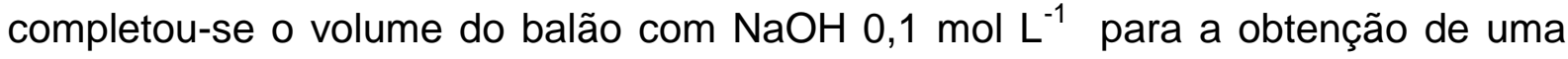
solução de concentração $500,0 \mu \mathrm{g} \mathrm{mL}^{-1}$. Em seguida esta solução foi submetida a uma temperatura de $80^{\circ} \mathrm{C}$.

Nos períodos de 0,15, 30, 60, 90 e 120 minutos foram retiradas alíquotas de $1 \mathrm{~mL}$ e transferidas para um balão de $10 \mathrm{~mL}$ e resfriadas a temperatura ambiente. Neutralizou-se com uma alíquota de $1 \mathrm{~mL}$ de $\mathrm{HCl} 0,1 \mathrm{~mol} \mathrm{~L}^{-1}$ e o volume foi completado com água. Obteve-se uma concentração final de 50,0 $\mu \mathrm{g} \mathrm{mL} \mathrm{m}^{-1}$, completando-se um tempo total de duas horas. A solução final foi injetada em triplicata.

\subsubsection{Linearidade}

Para definir a relação entre a resposta do instrumento e a concentração conhecida do analito, foi gerada uma curva de calibração com sete concentrações de solução de padrão, contendo o PI no caso da CZE.

A linearidade foi realizada primeiramente através do preparo da solução e curva analítica conforme descrito nos itens 5.2.4 e 5.2.5. Para a CLAE e CZE as soluções foram preparadas com fase móvel e eletrólito, respectivamente, Realizouse a seguir uma corrida analítica em ordem crescente de concentração, analisandose quatro vezes cada ponto da curva: $35,0,40,0,45,0,50,0,55,0,60,0$ e $65,0 \mu \mathrm{g} \mathrm{mL}$ ${ }^{1}$ em cada metodologia desenvolvida.

O resultado da linearidade foi expresso e demonstrado através da construção de um gráfico de calibração pelo método de regressão linear, uma equação de reta $(y=a x+b)$ e do coeficiente de correlação $\left(r^{2}\right)$. Para tanto, colocou-se no eixo $Y o$ cálculo de valores residuais. Nesse estudo utilizou-se o valor obtido com a média das áreas de cada concentração para a CLAE. Para o método de CZE utilizou-se a 
média das respostas de cada ponto obtida através da razão entre a área do pico do gemifloxacino e a área do pico do $\mathrm{PI}$.

\subsubsection{Limite de detecção (LD) e limite de quantificação (LQ)}

A determinação dos valores de LD e LQ foi calculada baseada na estimativa do desvio padrão da equação da curva analítica e inclinação da curva através das equações:

Limite de Detec ção $=3.3 \times \frac{\sigma}{S} \quad$ Limite de Quantificação $=10 \times \frac{\sigma}{S}$

Onde, $\sigma$ é a estimativa do desvio padrão da curva analítica e $S$ é a inclinação da curva analítica.

As concentrações encontradas através destas fórmulas, para linearidade de cada método, foram testadas preparando as soluções a partir de uma solução estoque (item 5.2.4.1) e analisadas sequencialmente por dez vezes em cada método.

\subsubsection{Precisão}

Neste estudo a precisão dos métodos desenvolvidos por CLAE e CZE foi baseada em dois ensaios diferentes: repetibilidade da precisão (precisão intra-dia) e precisão intermediária (precisão inter-dia). Ambas as análises são expressas em desvio padrão relativo (DPR) ou coeficiente de validação (CV).

$$
\text { DPR ou } C V=\frac{\sigma}{\bar{x}} \times 100
$$

Onde, $\sigma$ é o desvio padrão e $\bar{x}$ é a média das áreas ou respostas obtidas das análises.

\subsection{Repetibilidade}

Foi preparada uma solução de $500,0 \mu \mathrm{g} \mathrm{mL} \mathrm{m}^{-1}$ conforme descrito no item 5.2.4.1, Uma alíquota de $1 \mathrm{~mL}$ desta solução estoque foi transferida para um balão volumétrico de $10 \mathrm{~mL}$ e completou-se o volume com água para uma concentração final de $50,0 \mu \mathrm{g} \mathrm{m}^{-1}$. 
Outra solução preparada foi a da amostra de gemifloxacino a partir de uma solução estoque contendo $500,0 \mu \mathrm{g} \mathrm{mL}^{-1}$ de gemifloxacino (item 5.2.4.3). Uma alíquota $1 \mathrm{~mL}$ de da solução estoque foi transferida para balão volumétrico de 10 $\mathrm{mL}$. Completou-se o volume com água, obtendo-se para uma solução de amostra com concentração final de $50,0 \mu \mathrm{g} \mathrm{mL}^{-1}$ de gemifloxacino.

A injeção de cada solução foi realizada por dez vezes consecutivas para os métodos de CLAE e CZE desenvolvidos. No método da CLAE o DPR foi calculado a partir das áreas obtidas e no método por CZE, foi calculado a partir da razão da área do pico do gemifloxacino pela área do pico do PI (resposta). De acordo com a legislação vigente, o critério de aceitação para o DPR é de no máximo 5\%.

\subsection{Precisão intermediária}

Soluções estoque de padrão de gemifloxacino e PI (uso na EC) foram preparadas conforme os itens 5.2.4.1 e 5.2.4.2, respectivamente, e armazenadas sob refrigeração. Por três dias, em espaços de 24 horas, estas soluções foram diluídas até as concentrações de 40,0, 50,0 e 60,0 $\mathrm{g} \mathrm{mL}^{-1}$, conforme cálculos apresentados no item 5.2 .5 e injetadas por seis vezes consecutivas em ordem crescente de concentração.

No método por CLAE o DPR foi calculado a partir das áreas obtidas e no método por CZE foi calculado a partir da razão da área do pico do gemifloxacino pela área do pico do PI. De acordo com a legislação vigente, o critério de aceitação para o DPR é de no máximo $5 \%$.

\subsubsection{Exatidão}

A exatidão do método foi avaliada através do estudo de recuperação através da comparação do resultado do padrão com a amostra enriquecida com padrão.

As soluções estoque de padrão e amostra foram preparadas de acordo com os itens 5.2.4.1 a 5.2.4.2. Uma alíquota de $0,8 \mathrm{~mL}$ de solução de gemifloxacino 500 $\mu \mathrm{g} \mathrm{mL}^{-1}$ foi transferida para um balão volumétrico de $10 \mathrm{~mL}$ e completou-se o volume do balão com água, obtendo-se uma concentração de $40.0 \mu \mathrm{g} \mathrm{mL}^{-1}$. Com os mesmos valores, diluiu-se a solução de amostra de gemifloxacino em outro balão. 
As amostras enriquecidas foram preparadas a partir de ambas as soluções estoques. Nas três soluções a concentração da solução estoque foi mantida fixa, onde se transferiu uma alíquota de $0.8 \mathrm{~mL}$ para cada balão volumétrico de $10 \mathrm{~mL}$. Em seguida, adicionaram-se alíquotas de $0.1,0.2$ e $0.3 \mathrm{~mL}$ da solução estoque para os balões contendo a alíquota de solução da amostra. Completou-se o volume dos balões com água, obtendo-se as concentrações totais de gemifloxacino de 45.0, 50.0 e $55.0 \mu \mathrm{g} \mathrm{mL}^{-1}$, respectivamente, conforme Tabela 9.

As soluções de padrão e amostra foram analisadas por seis vezes consecutivas e as amostras enriquecidas por quatro vezes consecutivas em cada metodologia desenvolvida.

A exatidão/ recuperação é expressa em percentagem (\%R), na relação padrão e amostra. Para a CLAE, esse cálculo é baseado na média das áreas obtidas e no método da EC foi calculado a partir da razão da área do pico do gemifloxacino pela área do pico do PI. Para formas farmacêuticas, a legislação vigente tem como critério de aceitação a variação de até $2 \%$, ou seja, de 98 a 102\%.

Tabela 9. Concentrações utilizadas para o ensaio de recuperação

\begin{tabular}{lccc}
\hline & $\begin{array}{c}\text { Concentração } \\
\text { amostra }\left(\mu \mathrm{gL}^{-1}\right)\end{array}$ & $\begin{array}{c}\text { Concentração } \\
\text { padrão }\left(\mu \mathrm{mL}^{-1}\right)\end{array}$ & $\begin{array}{c}\text { Concentração total } \\
\text { de gemifloxacino } \\
\left(\mu \mathrm{mL}^{-1}\right)\end{array}$ \\
\hline Padrão & - & 40,0 & 40,0 \\
Amostra & 40,0 & - & 40,0 \\
Amostra Enriquecida 01 & 40,0 & 5,0 & 45,0 \\
Amostra Enriquecida 02 & 40,0 & 10,0 & 50,0 \\
Amostra Enriquecida 03 & 40,0 & 15,0 & 55,0 \\
\hline
\end{tabular}

\subsubsection{Análise estatística}

Os resultados das precisões (repetibilidade e intermediária) de ambos os métodos foram compiladas e analisadas através do software estatístico MiniTab ${ }^{\circledR}$ versão 15.

Quando se comparam estatisticamente, duas técnicas analíticas utilizadas para a mesma finalidade utilizam-se duas hipóteses: que a diferença entre ambas 
pode ser atribuída ao acaso ou de que elas possuem uma diferença significativa, não podendo neste último caso, ser intercambiáveis, Para cálculos foram empregados os testes de significância através dos testes $t$ e $F$.

O teste $t$ é utilizado para verificar a significância entre médias de valores experimentais obtidos por duas técnicas diferentes, Este valor possui determinados níveis de significância, e são tabelados. Quando o resultado experimental do teste $\mathrm{t}$ excede o valor tabelado, considera-se que a diferença é significativa, $\mathrm{O}$ valor de $\mathrm{t}$ é obtido pela equação:

$$
t=\frac{\bar{x}_{1}-\bar{x}_{2}}{s \sqrt{\frac{1}{n_{1}}+\frac{1}{n_{2}}}}
$$

Onde: $\bar{x}_{1}$ é a média obtida pelo Método 1;

$\bar{x}_{2}$ é a média obtida pelo Método 2;

S é o desvio padrão obtido pela raiz da variância calculada por ambos os métodos;

$\mathrm{n}_{1}$ e $\mathrm{n}_{2}$ são os números de amostras de cada técnica,

O teste $F$ é utilizado na comparação das precisões através dos desvios padrão de dois métodos diferentes, Da mesma forma que o teste $t$, o teste $F$ possui valores tabelados. Quando o resultado experimental excede o valor tabelado, considera-se que a diferença é significativa para determinado nível de significância, Este valor é obtido através da equação:

$$
F=\frac{S_{a}^{2}}{S_{b}^{2}}
$$

Onde: $S_{a}^{2}$ é o maior desvio padrão $S_{b}^{2}$ é o menor desvio padrão 

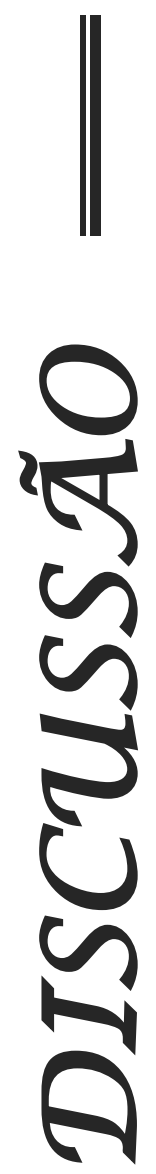

$H$

ชิ

0

6

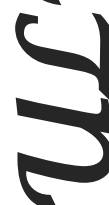

0

6 


\section{RESULTADOS E DISCUSSÃO}

\subsection{Gemifloxacino}

A pesquisa de novos agentes antimicrobianos tem sido contínua e crescente nos últimos anos, principalmente pelo rápido desenvolvimento da resistência bacteriana a antibióticos existentes no mercado e uso indiscriminado dos mesmos por parte da população e, muitas vezes, também da comunidade médica.

O número de quinolonas tem aumentado muito nos últimos anos. O crescimento acelerado é devido a ampla aceitação destes compostos no contexto mundial, por apresentarem eficácia de ação superior a de muitos fármacos de origem natural. Por pequenas modificações na estrutura química destes compostos, foram obtidos fármacos apresentando melhor espectro de ação. Este fato motivou a abertura de espaço para o constante avanço terapêutico na área.

\subsection{Controle de qualidade}

A melhor maneira de garantir a qualidade de um produto é controlar o processo de fabricação desde a seleção da matéria-prima até os produtos acabados e embalados, para que os mesmos atendam as especificações exigidas.

Com o aparecimento de um grande número de quinolonas quimicamente semelhantes, muitos métodos analíticos para a determinação qualitativa e quantitativa foram encontrados na literatura, mas muitos são direcionados ao monitoramento de resíduos e doseamento em fluidos biológicos, mas raros são os que apresentam a possibilidade de aplicação em controle físico-químico de qualidade, pois são procedimentos trabalhosos e custosos, ou seja, inviáveis para a rotina de um laboratório farmacêuticos de controle de qualidade.

Um dos maiores desafios para o controle de qualidade de formas acabadas é que o método analítico deve separar misturas complexas de princípios ativos e excipientes. Para tanto, na validação, a seletividade, mais especificamente, a avaliação de interferentes no placebo é um importante parâmetro a ser determinado. A validação de um método como um todo foi importante para a determinação da 
eficiência de cada técnica utilizada nesta pesquisa, visando a comparação dos resultados analíticos obtidos pelas duas técnicas analíticas selecionadas (CLAE e CZE).

\subsection{Determinação do comprimento de onda}

A solução de $100.0 \mathrm{ng} \mathrm{mL}^{-1}$ de gemifloxacino foi utilizada para efetuar uma varredura na região UV-vis visando o estabelecimento da leitura para faixa de $\lambda$ ideal. Para confirmação foram realizadas seis leituras (Figura 5), o que foi estabelecida a faixa entre 250 e $280 \mathrm{~nm}$.

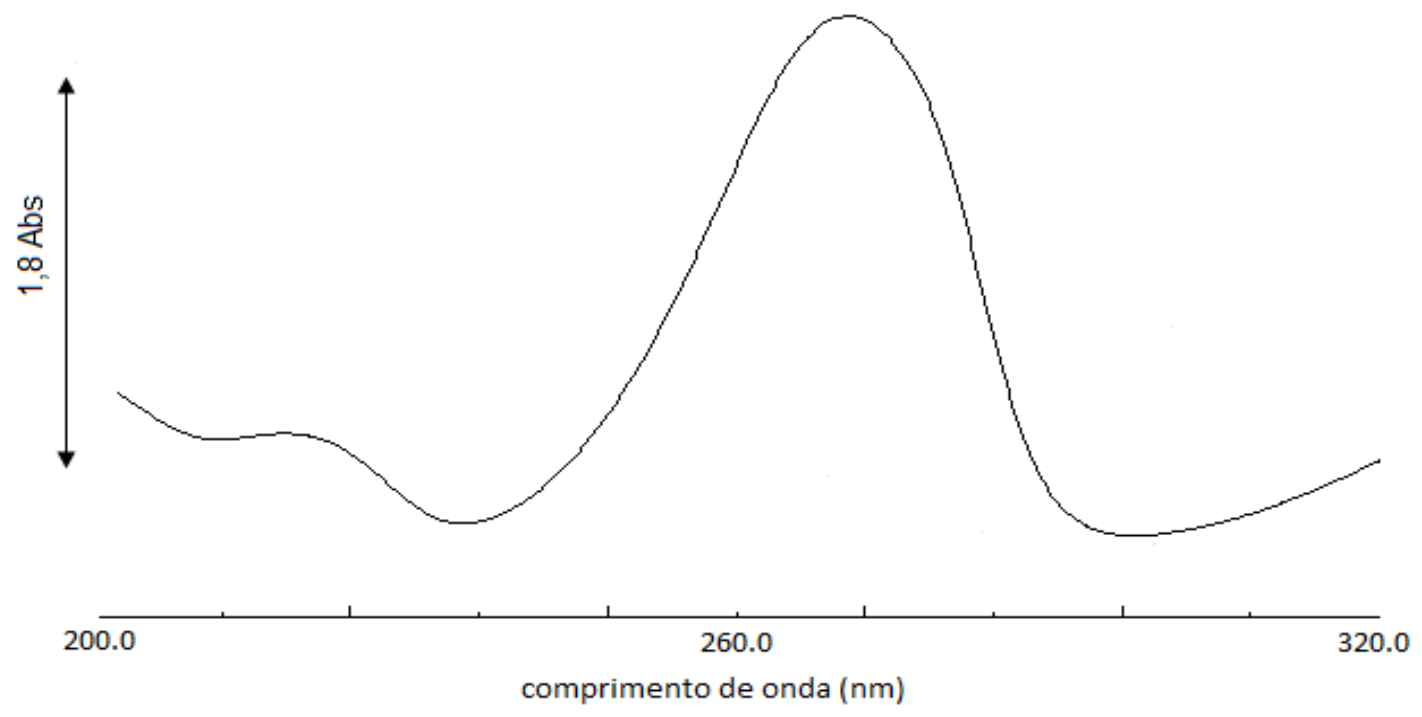

Figura 5. Espectro de absorção de gemifloxacino na concentração de $100.0 \mathrm{ng} \mathrm{mL}^{-1}$ em água.

\subsection{Cromatografia líquida de alta eficiência}

\subsubsection{Desenvolvimento do método}

Por ser uma técnica confiável e reprodutível, as principais condições a serem utilizadas no método desenvolvido foram obtidas através da literatura existente para outros compostos da classe das fluorquinolonas. Utilizou-se a fase móvel MeCN: trietilamina (TEA) $0.5 \%$ em pH 3.0 na proporção $20: 80$, vazão de $1 \mathrm{~mL} \mathrm{~min}^{-1}$ e volume 
de injeção de $10 \mu \mathrm{L}$ e coluna cromatográfica C8. Essas condições mostraram logo de início a simplicidade e a eficiência dos métodos, embora os cromatogramas obtidos tenham apresentado picos largos, ou seja, de alta assimetria (Figura 6).

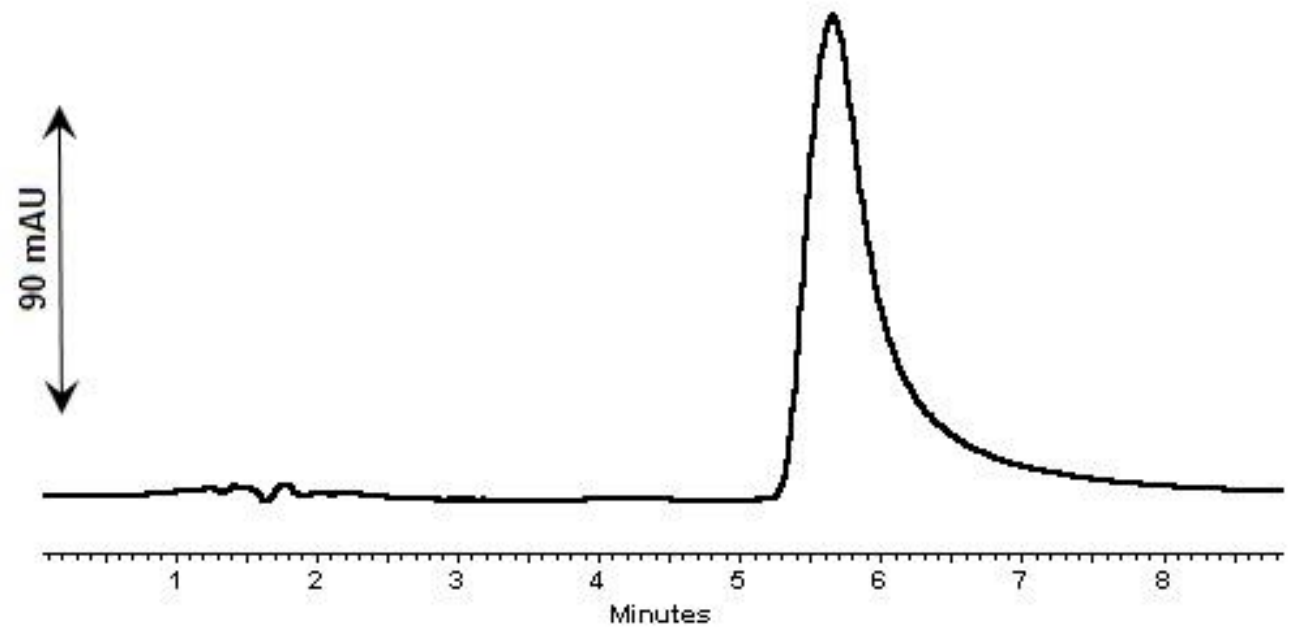

Figura 6. Cromatograma da solução de gemifloxacino $80,0 \mu \mathrm{g} \mathrm{mL}^{-1}$; Condições: coluna LiChrospher $100 \mathrm{RP}-8 \mathrm{e}(5 \mu \mathrm{m}, 125 \times 4 \mathrm{~mm})$, vazão: 1,0 mL min ${ }^{-1}$, fase móvel: MeCN: TEA 0.5\%, pH 3,0 ajustado com ácido ortofosfórico (20:80 v/v); detecção UV de $280 \mathrm{~nm}$.

Para adequar estes métodos ao equipamento do laboratório e ao gemifloxacino foram realizados alguns testes na fase móvel, a fim de obter-se um pico mais simétrico. Os ajustes na fase móvel foram feitos conforme os picos foram se adequando ao esperado.

O primeiro modificador orgânico testado foi a MeCN armazenada em uma das bombas do cromatógrafo. Na segunda bomba foi colocado o tampão TEA 0.5\% com pH 3.0 ajustado com ácido ortofosfórico. As proporções de fase orgânica e fase aquosa utilizadas foram 20:80, 25:75 e 30:70. Com a utilização de MeCN, os testes apresentaram picos largos, devido à baixa interação com o soluto, que ficou retido por mais tempo na coluna (Figura 7). 


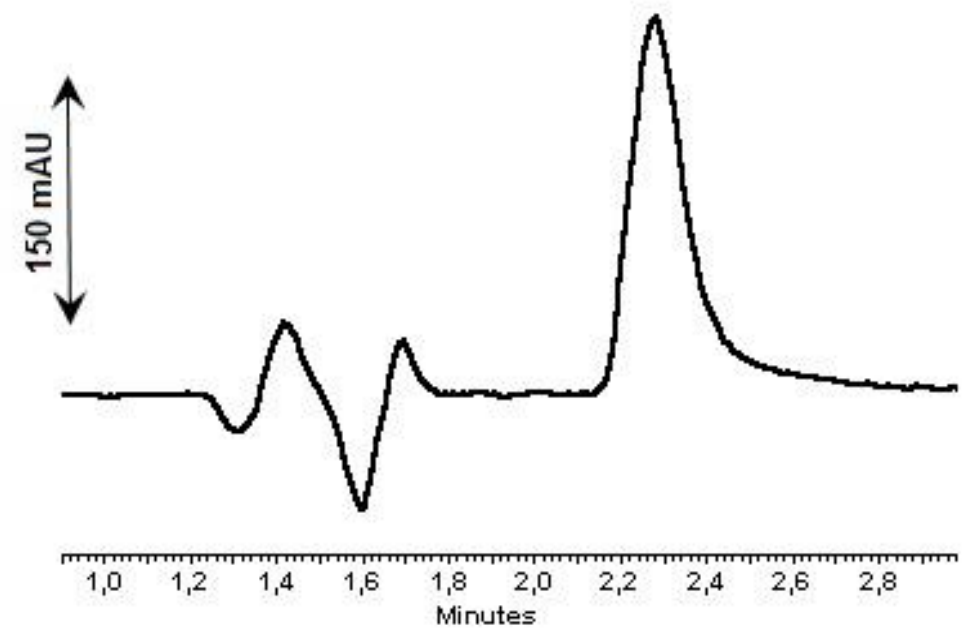

Figura 7. Cromatograma da solução de gemifloxacino $80.0 \mu \mathrm{g} \mathrm{mL}^{-1}$. Condições: coluna LiChrospher $100 \mathrm{RP}-8 \mathrm{e}(5 \mu \mathrm{m}, 125 \times 4 \mathrm{~mm})$; fase móvel MeCN: TEA 0.5\% pH 3.0 ajustado com ácido ortofosfórico $(30: 70 \mathrm{v} / \mathrm{v})$; fluxo: $1.0 \mathrm{~mL} \mathrm{~min}^{-1}$; detecção UV de $280 \mathrm{~nm}$.

Outro modificador utilizado foi $\mathrm{O} \mathrm{MeOH}$ que foi empregado com o mesmo tampão nas proporções 20:80 e 25:75. Conforme cromatograma apresentado na Figura 8, apesar da baixa assimetria, os tempos de retenção (tr) foram altos. Portanto, realizou-se uma alteração no tampão utilizando-se solução de acetato de amônio $10 \mathrm{mmol} \mathrm{L}^{-1}$, ou TFA $10 \mathrm{mmol} \mathrm{L}^{-1}$.

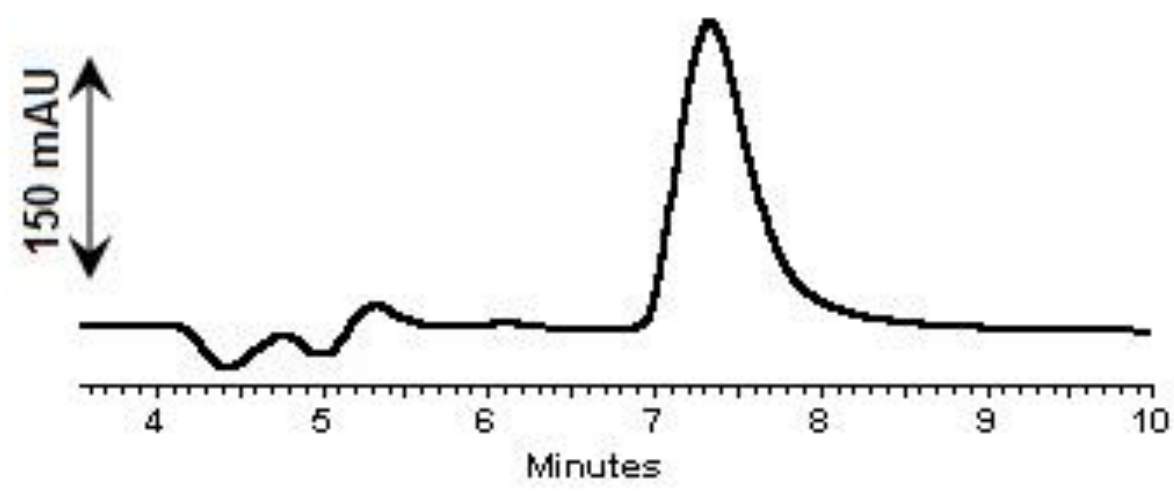

Figura 8. Cromatograma da solução de gemifloxacino $80,0 \mu \mathrm{g} \mathrm{mL}^{-1}$; Condições: coluna LiChrospher $100 \mathrm{RP}-8 \mathrm{e}(5 \mu \mathrm{m}, 125 \times 4 \mathrm{~mm})$; fase móvel MeOH: TEA 0,5\% $\mathrm{pH} 3,0$ ajustado com ácido ortofosfórico $(20: 80 \mathrm{v} / \mathrm{v})$; fluxo: $1,0 \mathrm{~mL} \mathrm{~min}^{-1}$; detecção UV de $280 \mathrm{~nm}$. 
Como a intenção foi o uso de pequenas quantidades de solventes orgânicos e a diminuição do tempo de retenção do gemifloxacino obtido quando se empregou MeCN e $\mathrm{MeOH}$, optou-se pelo uso de THF por ser o solvente para fase reversa com maior força, ou seja, que diminui a retenção de compostos pela diminuição da interação entre soluto e fase estacionária. O THF foi utilizado com o tampão TEA $0.5 \%$ em pH 3.0, nas proporções 40:60, 30:70, 25:75 e 20:80. Nestas condições foram obtidas maiores áreas, melhores simetrias de picos e menores tempos de retenção. Os melhores resultados foram alcançados quando utilizada a fase móvel na proporção 25:75. Esta fase móvel foi definida para proceder-se à validação da metodologia proposta por CLAE (Figura 9).

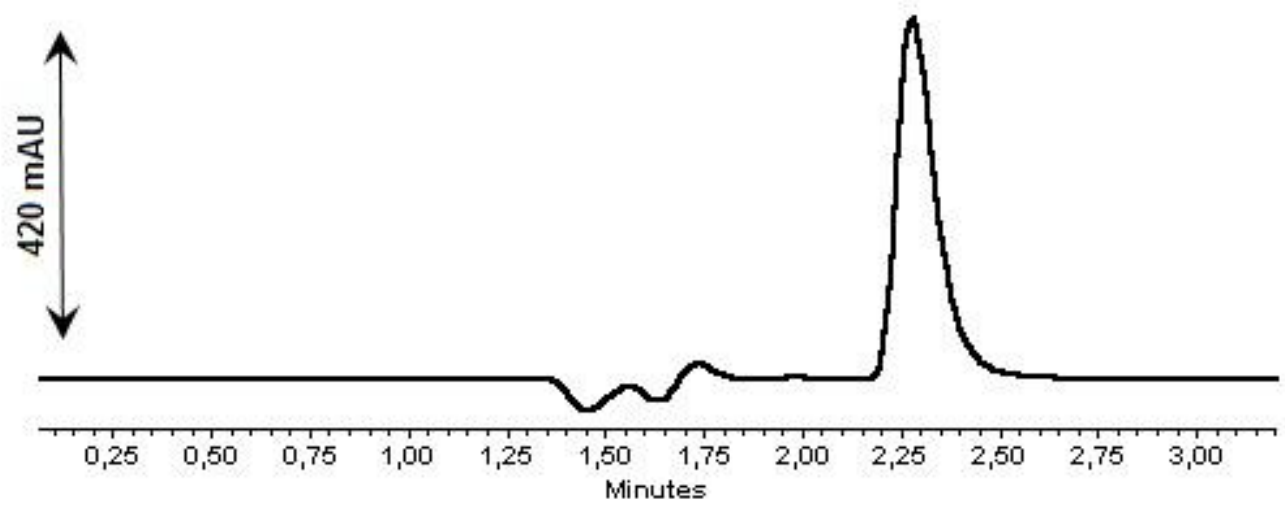

Figura 9. Cromatograma da solução de gemifloxacino $80,0 \mu \mathrm{g} \mathrm{m} \mathrm{m}^{-1}$. Condições: coluna LiChrospher 100 RP-8e $(5 \mu \mathrm{m}, 125$ x 4 mm); fase móvel THF: TEA 0,5\% pH 3,0 ajustado com ácido ortofosfórico (25:75 v/v); fluxo: 1,0 $\mathrm{mL} \mathrm{min}^{-1}$; detecção UV de $280 \mathrm{~nm}$.

\subsubsection{Validação do método por CLAE}

\subsubsection{Seletividade}

\subsection{Placebo}

Para avaliar a interferência de componentes da matriz, próximo ao tempo de retenção do fármaco (2,3 $\mathrm{min})$, os resultados foram comparados com aqueles obtidos com uma solução aquosa do analito a ser analisado em concentração próxima ao LQ. Os resultados obtidos após a injeção no cromatógrafo de uma 
solução de placebo mostraram que não foram observadas interferências significativas no método (Figura 10).

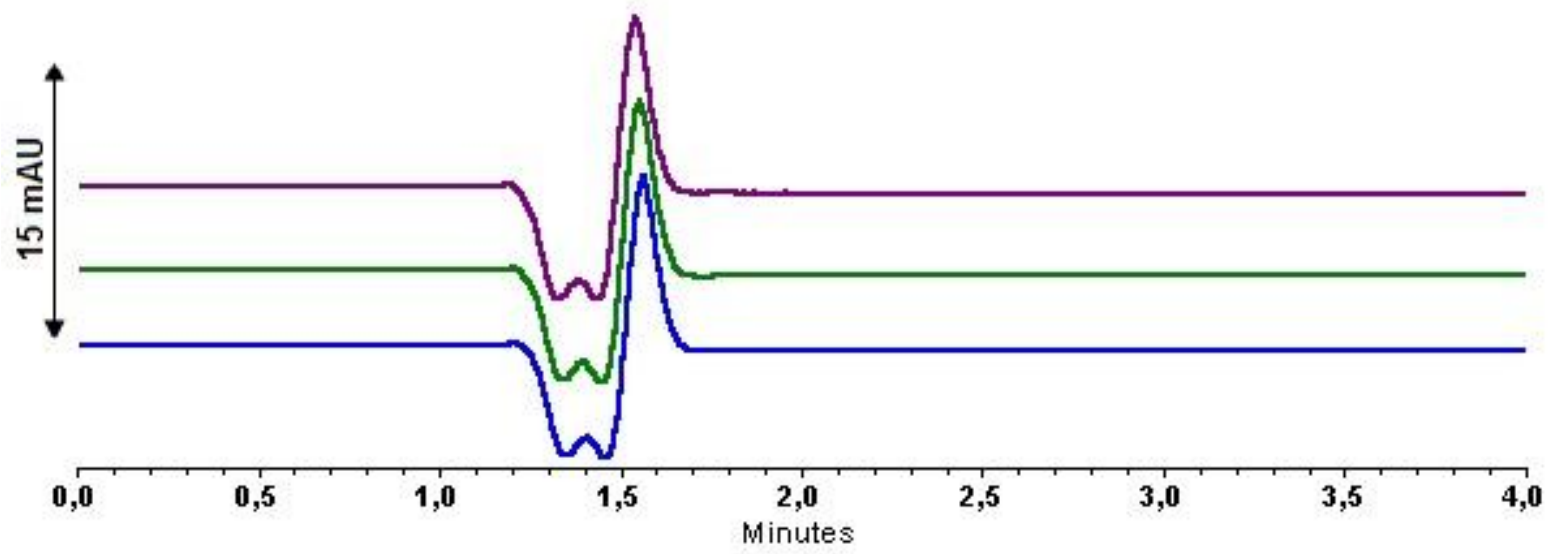

Figura 10. Cromatograma da solução de placebo. Condições: coluna LiChrospher

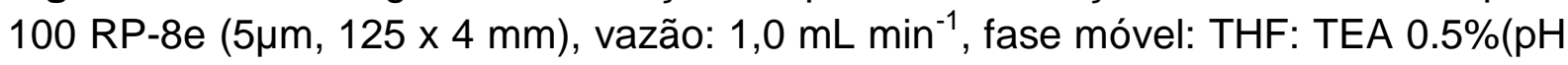
$3,0)$ ajustado com ácido ortofosfórico (25:75 v/v); detecção UV de $280 \mathrm{~nm}$.

\subsection{Teste de estresse}

\subsection{Hidrólise em meio neutro}

Conforme apresentado na Figura 11, a hidrólise em meio neutro não provocou a degradação do gemifloxacino, não havendo mudança no tempo de retenção, e, somente diminuição do pico após $2 \mathrm{~h}$ sob aquecimento a $80^{\circ} \mathrm{C}$.

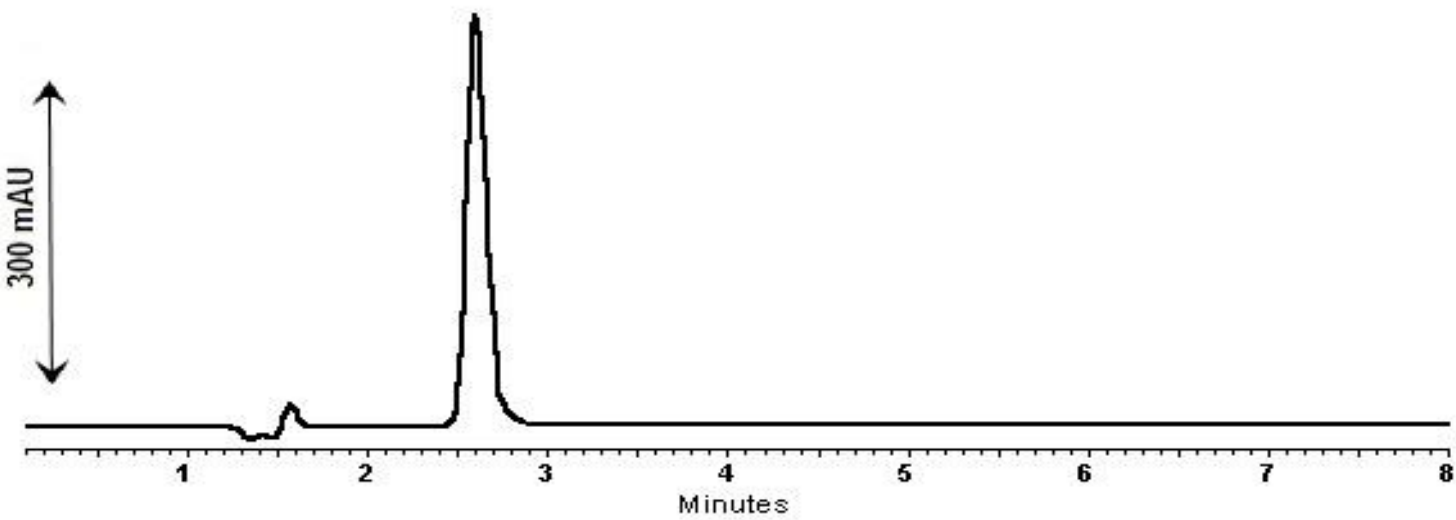

Figura 11. Cromatograma da solução de gemifloxacino $50,0 \mu \mathrm{g} \mathrm{mL}^{-1}$ após hidrólise em meio neutro após $2 \mathrm{~h}$. Condições: coluna LiChrospher $100 \mathrm{RP}-8 \mathrm{e}(5 \mu \mathrm{m}, 125 \times 4$ $\mathrm{mm}$ ), vazão: 1,0 $\mathrm{mL} \mathrm{min}^{-1}$, fase móvel: THF: TEA 0,5\% (pH 3,0) ajustado com ácido ortofosfórico (25:75 v/v); detecção UV de $280 \mathrm{~nm}$. 


\subsection{Hidrólise em meio oxidativo}

Na Figura 12 pode-se observar o aparecimento de picos desconhecidos, com baixa intensidade, que eluiram no tempo do volume morto, após a oxidação química com $\mathrm{H}_{2} \mathrm{O}_{2} 3 \%$.

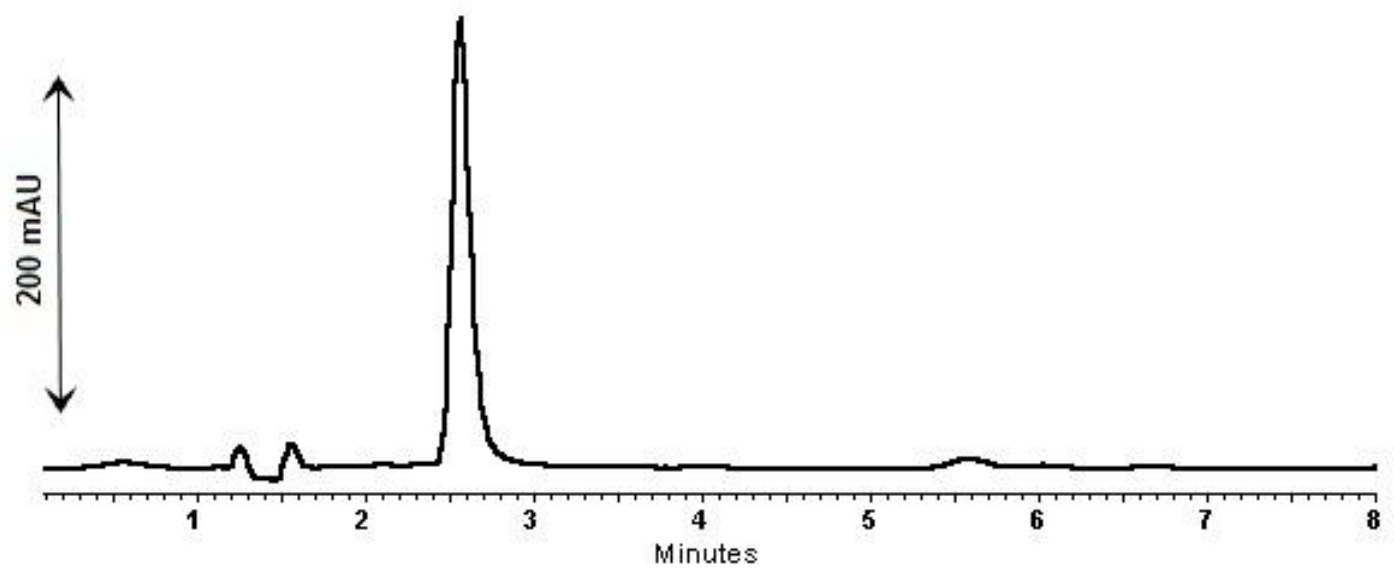

Figura 12. Cromatograma da solução de gemifloxacino $50,0 \mu \mathrm{g} \mathrm{mL}^{-1}$ após hidrólise em meio oxidativo após $2 \mathrm{~h}$. Condições: coluna LiChrospher $100 \mathrm{RP}-8 \mathrm{e}(5 \mu \mathrm{m}, 125 \mathrm{x}$ $4 \mathrm{~mm}$ ), vazão: $1,0 \mathrm{~mL} \mathrm{~min}{ }^{-1}$, fase móvel: THF: TEA $0.5 \%(\mathrm{pH} \mathrm{3,0)}$ ajustado com ácido ortofosfórico $(25: 75 \mathrm{v} / \mathrm{v})$; detecção UV de $280 \mathrm{~nm}$.

\subsection{Hidrólise em meio ácido}

$\mathrm{Na}$ hidrólise em meio ácido com $\mathrm{HCl} 0,1 \mathrm{mmol} \mathrm{L}^{-1}$, apresentada na Figura 13 , apareceram, no mesmo tempo de retenção do gemifloxacino, picos desconhecidos com respostas instrumentais significativas. 


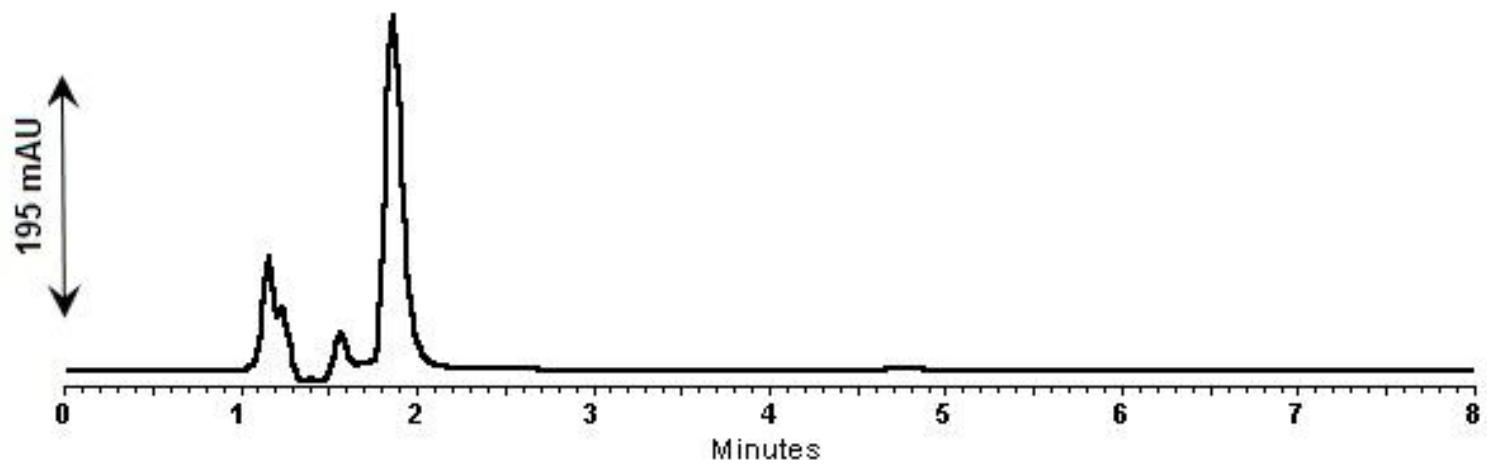

Figura 13. Cromatograma da solução de gemifloxacino $50,0 \mu \mathrm{g} \mathrm{mL}^{-1}$ após hidrólise em meio ácido após 2h. Condições: coluna LiChrospher $100 \mathrm{RP}-8 \mathrm{e}(5 \mu \mathrm{m}, 125 \times 4$ $\mathrm{mm}$ ), vazão: 1,0 $\mathrm{mL} \mathrm{min}^{-1}$, fase móvel: THF: TEA 0.5\% (pH 3,0) ajustado com ácido ortofosfórico (25:75 v/v); detecção UV de $280 \mathrm{~nm}$.

\subsection{Hidrólise em meio básico}

A Figura 14 mostra aparecimento de picos desconhecidos com baixa detecção em relação ao gemifloxacino eluindo, principalmente, no intervalo de tempo do volume morto.

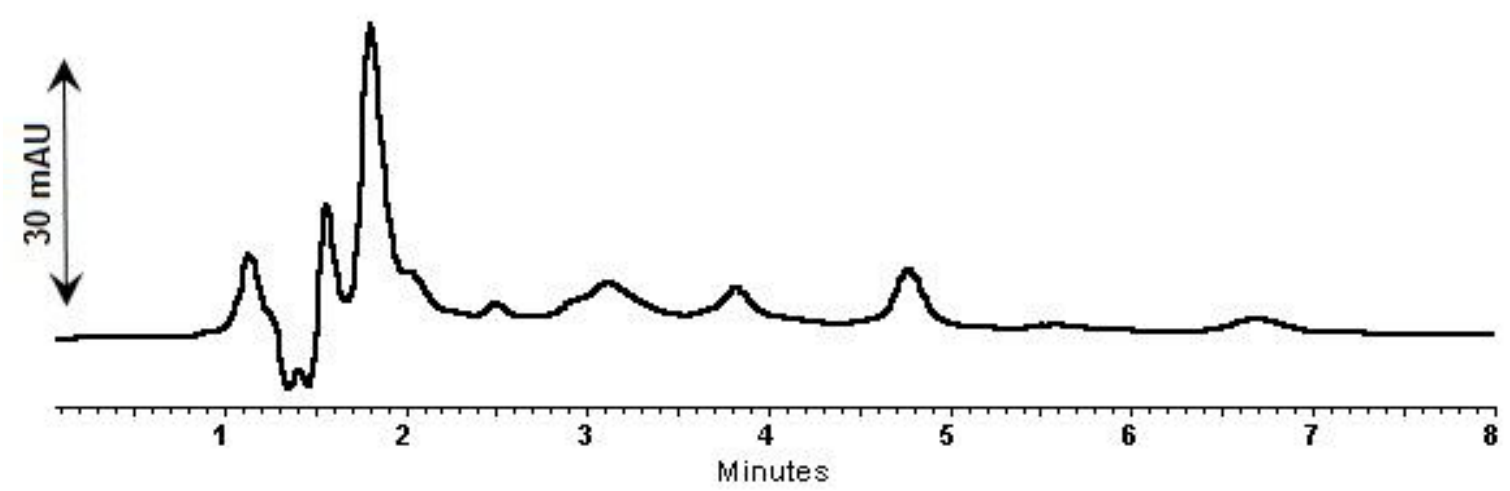

Figura 14. Cromatograma da solução de gemifloxacino $50,0 \mu \mathrm{g} \mathrm{mL}^{-1}$ após hidrólise em meio básico após $2 \mathrm{~h}$. Condições: coluna LiChrospher $100 \mathrm{RP}-8 \mathrm{e}(5 \mu \mathrm{m}, 125 \times 4$ $\mathrm{mm}$ ), vazão: $1,0 \mathrm{~mL} \mathrm{~min}^{-1}$, fase móvel: THF: TEA $0.5 \%(\mathrm{pH} 3,0)$ ajustado com ácido ortofosfórico (25:75 v/v); detecção UV de $280 \mathrm{~nm}$.

\subsection{Linearidade}

Para definir a relação entre a resposta do instrumento e a concentração conhecida do analito, foi gerada uma curva analítica com sete diferentes concentrações da solução do padrão. A Figura 15 apresenta a sobreposição dos 
cromatogramas. Na Figura 16 pode ser observada a curva analítica e na Tabela 10 estão indicados os valores matemáticos obtidos através da análise estatística.

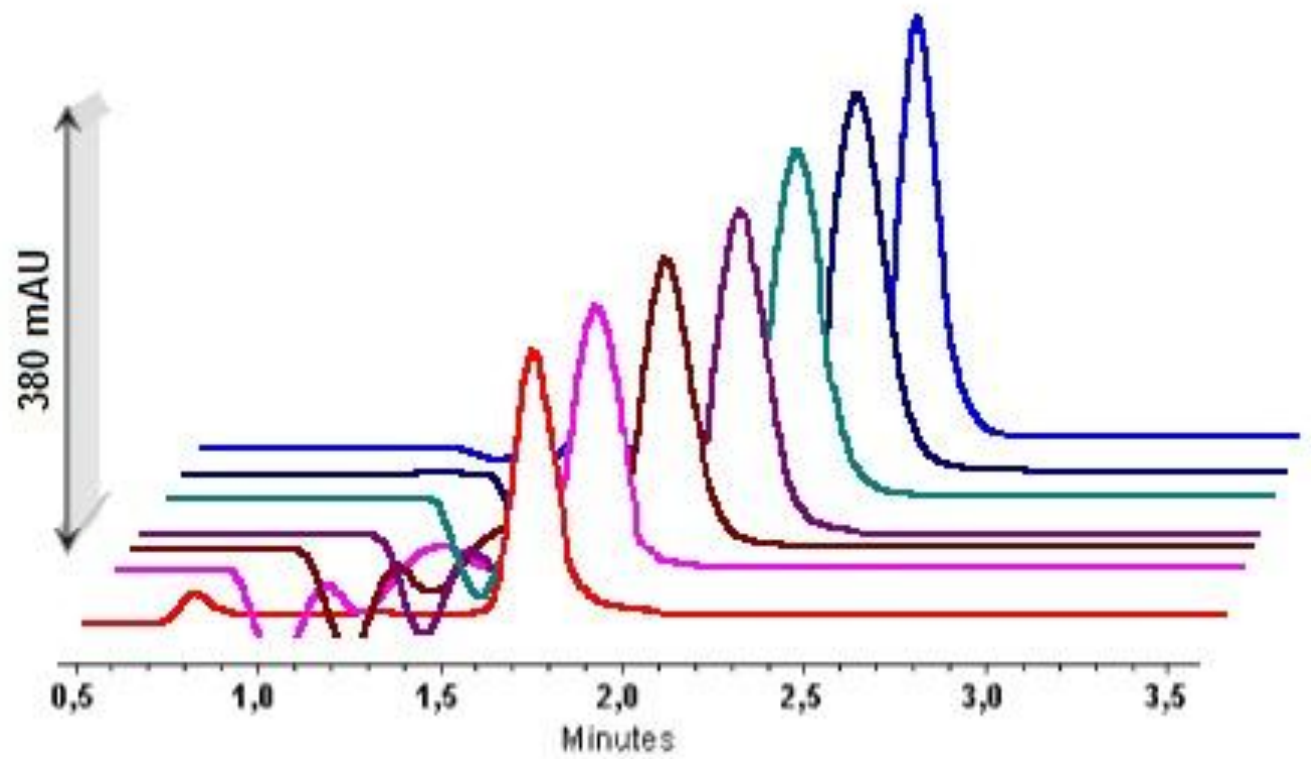

Figura 15. Sobreposição dos cromatogramas da curva analítica nas concentrações de 35,0 a 65,0 $\mu \mathrm{g} \mathrm{mL}^{-1}$. Condições: coluna LiChrospher $100 \mathrm{RP}-8 \mathrm{e}(5 \mu \mathrm{m}, 125$ x 4 $\mathrm{mm}$ ), vazão: 1,0 mL $\mathrm{min}^{-1}$, fase móvel: THF: TEA 0.5\% (pH 3,0) ajustado com ácido ortofosfórico (25:75 v/v); detecção UV de $280 \mathrm{~nm}$.

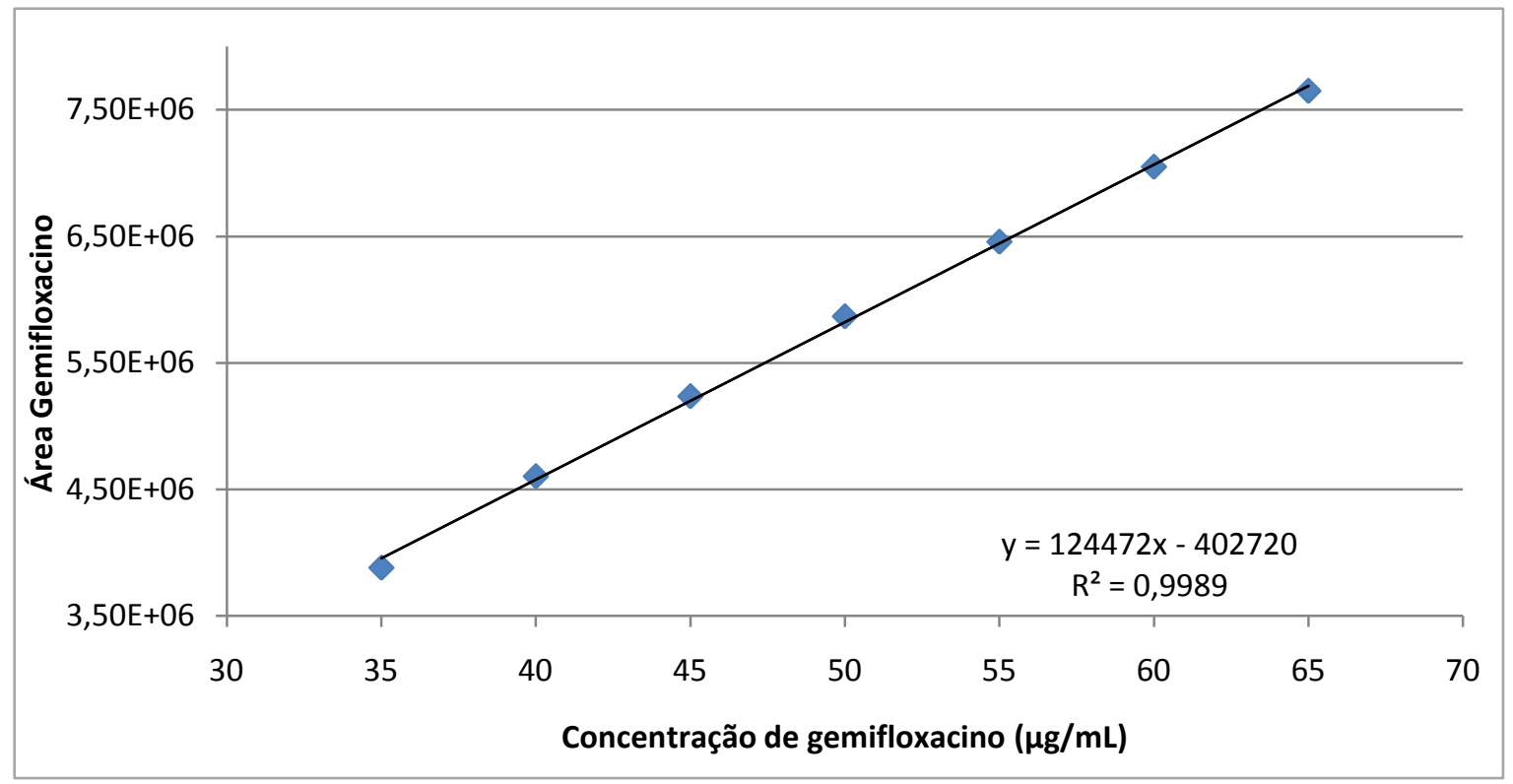

Figura 16. Curva de calibração do gemifloxacino na faixa de concentração de 35,0 a $65,0 \mu \mathrm{g} \mathrm{mL}{ }^{-1}$. 
Tabela 10. Resultados experimentais obtidos na determinação da curva analítica do gemifloxacino. Método: CLAE

\begin{tabular}{|c|c|}
\hline $\begin{array}{c}\text { Concentração de leitura } \\
(\mu \mathrm{g} / \mathrm{mL})\end{array}$ & $\begin{array}{c}\text { Área fármaco* } \\
\left(\times 10^{6}\right)\end{array}$ \\
\hline 35,0 & 3,88 \\
\hline 40,0 & 4,60 \\
\hline 45,0 & 5,24 \\
\hline 50,0 & 5,87 \\
\hline 55,0 & 6,46 \\
\hline 60,0 & 7,05 \\
\hline 65,0 & 7,65 \\
\hline Inclinação (b) & 124472 \\
\hline Desvio padrão da inclinação $\left(S_{b}\right)$ & 1821 \\
\hline Intercepto (a) & -402720 \\
\hline Desvio padrão do intercepto $\left(S_{a}\right)$ & 92860 \\
\hline Erro padrão da estimativa (Se) & 48182 \\
\hline Coeficiente de correlação $(r)$ & 0,9989 \\
\hline
\end{tabular}

${ }^{*}$ Média de quatro leituras.

Os resultados apresentados indicam boa linearidade do método proposto com coeficiente de correlação linear (r) de 0,9989.

\subsection{Limite de detecção (LD) e limite de quantificação (LQ)}

O LQ obtido representa a menor concentração em que o gemifloxacino pode ser determinado por CLAE com precisão e exatidão aceitáveis e o LD foi calculado como sendo correspondente à concentração de gemifloxacino que teoricamente produz um valor do sinal medido 3.3 vezes maior do que o nível de ruído médio. Os valores encontrados estão apresentados na Tabela 11 e mostram resultados aceitáveis sob as condições experimentais estabelecidas. 
Tabela 11. Resultados obtidos na determinação dos limites de detecção e quantificação do gemifloxacino. Método: CLAE

\begin{tabular}{cc}
\hline Parâmetro & Gemifloxacino $\left(\mu \mathrm{g} \mathrm{mL}^{-1}\right)$ \\
\hline Limite de deteção & 0,33 \\
Limite de quantificação & 0,99 \\
\hline
\end{tabular}

\subsection{Precisão}

A Tabela 12 apresenta os resultados obtidos na avaliação da repetibilidade do método através da injeção consecutiva de uma única concentração da solução do padrão e a Tabela 13 mostra os resultados obtidos na precisão intermediária do método, medida através da injeção, por três dias consecutivos, de três soluções do padrão em diferentes concentrações.

Tabela 12. Resultados obtidos na determinação da repetibilidade (precisão). Método: CLAE

\begin{tabular}{c|c}
\hline $\begin{array}{c}\text { Concentração padrão } \\
\left(\mu \mathrm{g} \mathrm{mL}^{-1}\right)\end{array}$ & Área fármaco \\
\hline 50,0 & 5207546 \\
50,0 & 5275538 \\
50,0 & 5267209 \\
50,0 & 5242765 \\
50,0 & 5248364 \\
50,0 & 5222695 \\
50,0 & 5242123 \\
50,0 & 5282147 \\
50,0 & 5247915 \\
50,0 & 5299898 \\
\hline Média & $\mathbf{5 2 5 3 6 2 0}$ \\
Desvio padrão & $\mathbf{2 7 9 0 8 , 3}$ \\
Desvio padrão relativo & $\mathbf{0 , 5 3}$ \\
\hline
\end{tabular}


Tabela 13. Resultados obtidos na determinação na precisão intermediária realizada em três dias consecutivos. Método: CLAE

\begin{tabular}{|c|c|c|c|c|}
\hline INTER-DIA & $\begin{array}{l}\text { Parâmetros } \\
\text { estatísticos* }\end{array}$ & $\begin{array}{c}35,0 \mu \mathrm{g} \mathrm{mL^{-1 }} \\
\left(\times 10^{6}\right)\end{array}$ & $\begin{array}{c}50,0 \mu \mathrm{g} \mathrm{mL}^{-1} \\
\left(\times 10^{6}\right)\end{array}$ & $\begin{array}{c}65,0 \mu \mathrm{g} \mathrm{mL}^{-1} \\
\left(\times 10^{6}\right)\end{array}$ \\
\hline \multirow{2}{*}{ Dia 01} & Média & $3,65 \mathrm{e} 6$ & $5,25 e 6$ & $7,65 \mathrm{e} 6$ \\
\hline & DPR (\%) & 1,15 & 0,53 & 0,28 \\
\hline \multirow{2}{*}{ Dia 02} & Média & $3,67 e 6$ & $5,24 \mathrm{e} 6$ & $7,64 \mathrm{e} 6$ \\
\hline & DPR (\%) & 1,01 & 0,47 & 0,55 \\
\hline \multirow{2}{*}{ Dia 03} & Média & $3,62 \mathrm{e} 6$ & $5,26 \mathrm{e} 6$ & $7,64 \mathrm{e} 6$ \\
\hline & DPR (\%) & 0,17 & 0,32 & 0,08 \\
\hline
\end{tabular}

Os resultados encontrados mostram que o método de CLAE é preciso. Os valores dos DPR obtidos variaram entre 0,08 e 1,15, e estão abaixo do valor máximo permitido que é de $5,00 \%$. Foi assim comprovada a baixa variabilidade do método e a estabilidade das soluções do fármaco.

\subsection{Exatidão}

A exatidão do método indica o quanto os resultados obtidos, sob as condições experimentais desenvolvidas, estão próximos ao valor teórico. A exatidão do método foi demonstrada através do teste de recuperação. Após a adição de diferentes concentrações da solução do padrão à solução da amostra e análise pelo método proposto, foram obtidos resultados de recuperação, próximos à $100 \%$. Os dados estão apresentados na Tabela 14. 
Tabela 14. Resultados obtidos no teste de recuperação do gemifloxacino. Método: CLAE

\begin{tabular}{ccccc}
\hline $\begin{array}{c}\text { Área } \\
\text { fármaco }\end{array}$ & $\begin{array}{c}\text { Padrão adicionado } \\
\left(\mu \mathrm{g} \mathrm{mL}^{-1}\right)\end{array}$ & $\begin{array}{c}\text { Área } \\
\text { Amostra }^{*}\end{array}$ & $\begin{array}{c}\text { Recuperação } \\
(\%)\end{array}$ & $\begin{array}{c}\text { Média da recuperação } \\
\mathbf{\pm} \text { DPR }\end{array}$ \\
\hline \multirow{2}{*}{4687067} & 5.0 & 5249055 & 100,8 & \\
& 10.0 & 5886905 & 100,1 & $100,6 \pm 0,5$ \\
\hline
\end{tabular}

${ }^{*}$ média de quatro determinações

\subsection{Eletroforese capilar}

\subsubsection{Desenvolvimento do método}

Após a revisão da literatura foram consideradas para o desenvolvimento do método as seguintes condições: TBS $10 \mathrm{mmol} \mathrm{L}^{-1}$ como solução tampão, capilar de sílica fundida com $40,2 \mathrm{~cm}$ (30 cm efetivo) $\times 75 \mu \mathrm{m}$ d.i. $\times 375 \mu \mathrm{m}$ d.e.; $+18 \mathrm{kV}$ a $18^{\circ} \mathrm{C}$ (ou $+22 \mathrm{kV}$ e $22^{\circ} \mathrm{C}$ ), introdução da amostra de 0,5 psi por $5 \mathrm{~s}$. Os melhores resultados (Figura 17) foram obtidos empregando-se $+18 \mathrm{kV}$ a $18^{\circ} \mathrm{C}$.

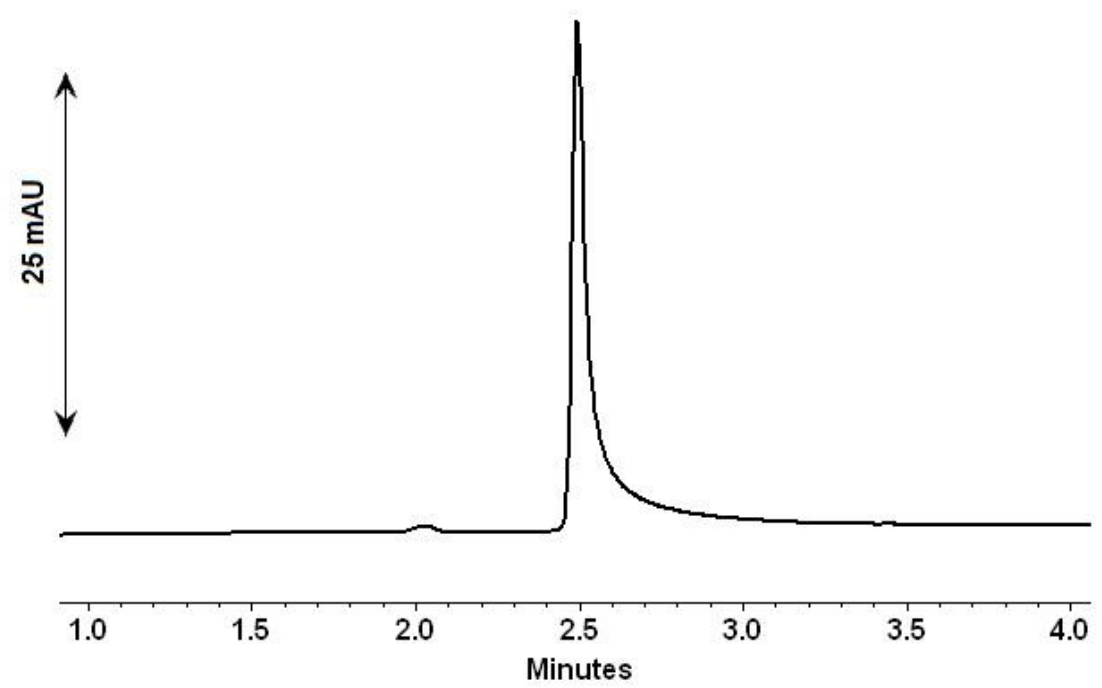

Figura 17. Eletroferograma referente ao pico do gemifloxacino na concentração de $100,0 \mu \mathrm{g} \mathrm{mL}^{-1}$. Condições: voltagem de $+18 \mathrm{kV}$, temperatura de $18^{\circ} \mathrm{C}$. Condições: 5 $\mathrm{s}$ de injeção a 0.5 psi, e tampão de tetraborato de sódio $10 \mathrm{mmol} \mathrm{L}^{-1}$ e absorção UV em $280 \mathrm{~nm}$. 
Em seguida, conforme Figura 18, foram testadas variações nas concentrações de TBS de 40 a $60 \mathrm{mmol} \mathrm{L}^{-1}$. Apesar do aumento da intensidade dos picos, a presença de cauda posterior aumentou proporcionalmente à concentração de eletrólito e na concentração de $60 \mathrm{mmol} \mathrm{L}^{-1}$, foi verificada uma cauda frontal.

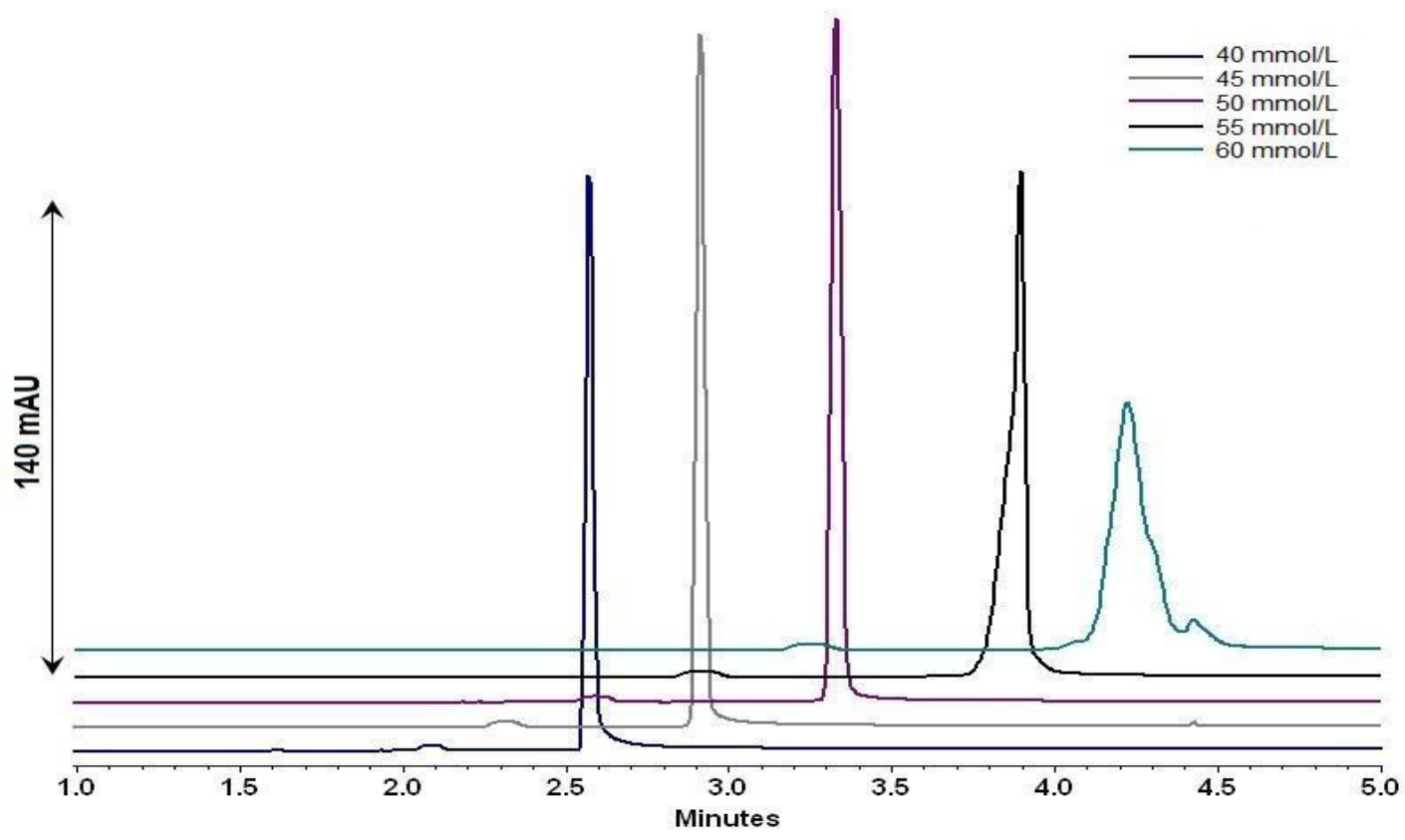

Figura 18. Eletroferogramas referente ao pico do gemifloxacino na concentração de $100,0 \mu \mathrm{g} \mathrm{mL}{ }^{-1}$. Eletrólito de corrida de TBS na concentração de 40 a $60 \mathrm{mmol} \mathrm{L}^{-1}$. Condições: voltagem de $+18 \mathrm{kV}$, temperatura de $18^{\circ} \mathrm{C}$, introdução hidrodinâmica da amostra por 5 s a 0.5 psi e detecção no UV em 280 nm.

Visando a diminuição da cauda posterior do pico, na concentração de 50 mmol $\mathrm{L}^{-1}$, realizaram-se testes com a adição de aditivos no eletrólito, como TEA, Brij $^{\circledR}$, SDS, fosfato de sódio e acetato de amônio. Em todos os casos houve uma intensa diminuição no sinal do analito, alargamento das bandas e aumento no tempo de migração. Quando SDS e Brij ${ }^{\circledR}$ foram empregados, observou-se a formação de espuma no eletrólito e conseqüente queda na corrente durante as corridas.

Foram realizados testes empregando-se o tampão TBS $50 \mathrm{mmol} \mathrm{L}^{-1}$, com diferentes combinações de voltagem e temperatura: $18 \mathrm{kV}$ e $18^{\circ} \mathrm{C}, 20 \mathrm{kV}$ e $18^{\circ} \mathrm{C}, 22$ $\mathrm{kV}$ e $18^{\circ} \mathrm{C}, 24 \mathrm{kV}$ e $18^{\circ} \mathrm{C}, 26 \mathrm{kV}$ e $18^{\circ} \mathrm{C}, 18 \mathrm{kV}$ e $20^{\circ} \mathrm{C}, 20 \mathrm{kV}$ e $20^{\circ} \mathrm{C}, 20 \mathrm{kV}$ e $22^{\circ} \mathrm{C}$ e $18 \mathrm{kV}$ e $24^{\circ} \mathrm{C}$. Foi observado que, quando as voltagens empregadas estavam acima de $20 \mathrm{kV}$, resultavam na formação de altas correntes no campo elétrico formado, e, impedindo a detecção de um sinal. Em temperaturas acima de $20^{\circ} \mathrm{C}$ não foram observados picos definidos. Assim sendo, foram selecionados os parâmetros de +18 
$\mathrm{kV}$ e $18^{\circ} \mathrm{C}$, quando os picos do gemifloxacino apresentaram baixa assimetria de 0,99 (máximo aceitável é 2,0).

Para a escolha do tampão foram efetuados testes com variações do valor de $\mathrm{pH}(4,0$ e 6,0 a 10,0). Os melhores resultados foram obtidos em pH de 8,6, ajustado pela adição cuidadosa de uma solução de ácido ortofosfórico $0,1 \mathrm{~mol} \mathrm{~L}^{-1}$.

Após a escolha do eletrólito, foram realizados testes para a determinação do melhor comprimento de onda para o método. Os melhores resultados encontrados fora os que utilizaram $263 \mathrm{~nm}$.

Um fator que pode limitar o emprego do método é a variação de picos entre as injeções. A EC, por ser uma técnica relativamente, optou-se pelo uso de um $\mathrm{PI}$, visando a correção deste possível fator de erro. Os resultados das análises, a partir desse momento, foram expressos pela razão área do pico do gemifloxacino pela área do pico do PI. A escolha do PI adequado foi feita com base nas características químicas semelhantes ao fármaco estudado, isto é, ser solúvel em água e apresentar tempo de migração menor do que o gemifloxacino.

Foram testados três padrões de fármacos da mesma classe: levofloxacino, ciprofloxacino e pefloxacino, nas concentrações de 100,0 $\mathrm{g} \mathrm{mL}^{-1}$ em água. Todos apresentaram baixa resolução entre os picos, devido apresentarem tempo de migração semelhante ao do analito. Outros padrões testados foram: dipirona, metoprolol, atenolol, diclofenaco, artovastatina, ibuprofeno e cetoconazol nas concentrações de $500,0 \mu \mathrm{g} \mathrm{mL} \mathrm{m}^{-1}$ em água. Onde estes três últimos não apresentaram solubilidade em água. O melhor comportamento nas condições estabelecidas foi apresentado pelo metoprolol.

\subsubsection{Validação do método por eletroforese capilar}

\subsection{Placebo}

Para avaliar a interferência de componentes da matriz no tempo de retenção do fármaco (2.55 min) e do padrão interno (1.65 min) foi analisado, nas condições estabelecidas o placebo da amostra selecionado para o estudo. Os resultados obtidos através da injeção de uma solução de placebo mostraram que os excipientes não interferiram no método (Figura 19). 


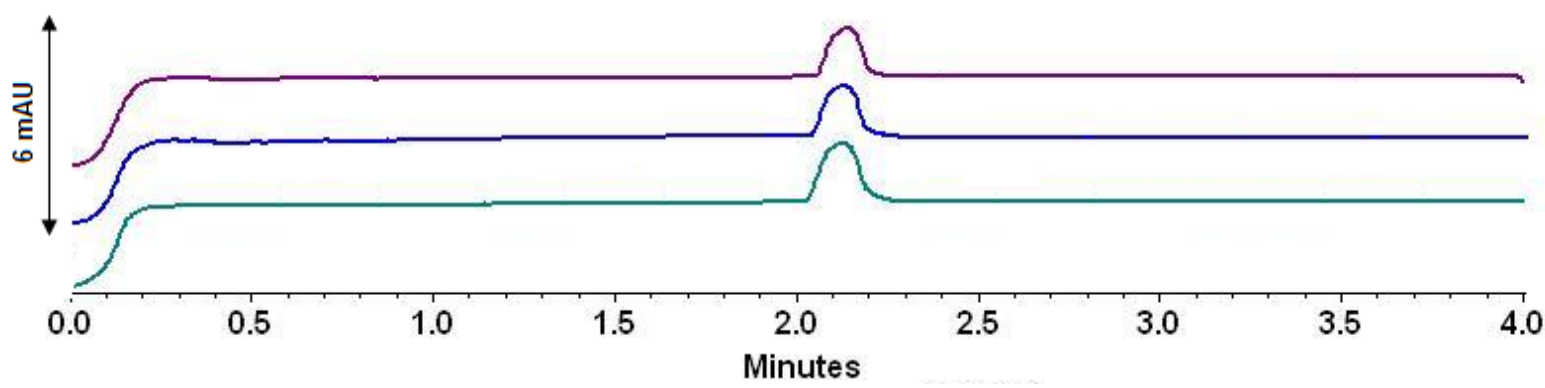

Figura 19. Eletroferograma da solução de placebo Condições: capilar de sílica fundida com 40,2 cm (30 cm efetivo) x $75 \mu \mathrm{m}$ (d.i.) $\times 375 \mu \mathrm{m}$ (d.e.); eletrólito: tampão tetraborato de sódio $50 \mathrm{mmol} \mathrm{L}^{-1}(\mathrm{pH} \mathrm{8,6)}$; voltagem de $+18 \mathrm{kV}$; temperatura de $18^{\circ} \mathrm{C}$; introdução hidrodinâmica da amostra por 5 s a 0,5 psi e absorção UV em 263 $\mathrm{nm}$.

\subsection{Teste de estresse}

\subsection{Hidrólise em meio neutro}

O eletroferograma apresentado na Figura 20 indica que a hidrólise em meio neutro não apresentou degradação do gemifloxacino, no tempo de retenção, apenas a diminuição da intensidade do sinal após $2 \mathrm{~h}$ sob aquecimento a $80^{\circ} \mathrm{C}$.

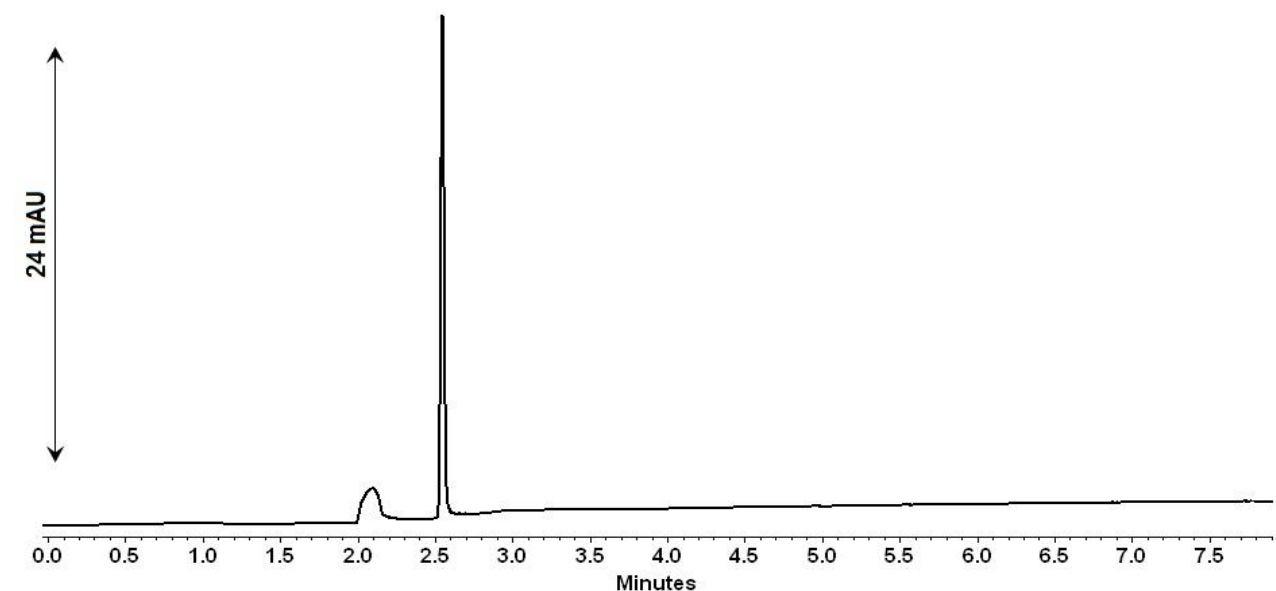

Figura 20. Eletroferograma da solução de gemifloxacino $50,0 \mu \mathrm{g} \mathrm{mL}^{-1}$ após $2 \mathrm{~h}$ de hidrólise em meio neutro. Condições: capilar de sílica fundida com 40,2 cm (30 cm efetivo) $\times 75 \mu \mathrm{m}$ (d.i.) $\times 375 \mu \mathrm{m}$ (d.e.); eletrólito: tampão tetraborato de sódio 50 mmol $\mathrm{L}^{-1}(\mathrm{pH} 8,6)$; voltagem de $+18 \mathrm{kV}$; temperatura de $18^{\circ} \mathrm{C}$; introdução hidrodinâmica da amostra por 5 s a 0,5 psi e absorção UV em 263 nm. 


\subsection{Hidrólise em meio oxidativo}

Na Figura 21 pode-se observar o aparecimento de picos desconhecidos, a maioria com baixa intensidade ao longo da corrida, após a oxidação química com $\mathrm{H}_{2} \mathrm{O}_{2} 3 \%$.

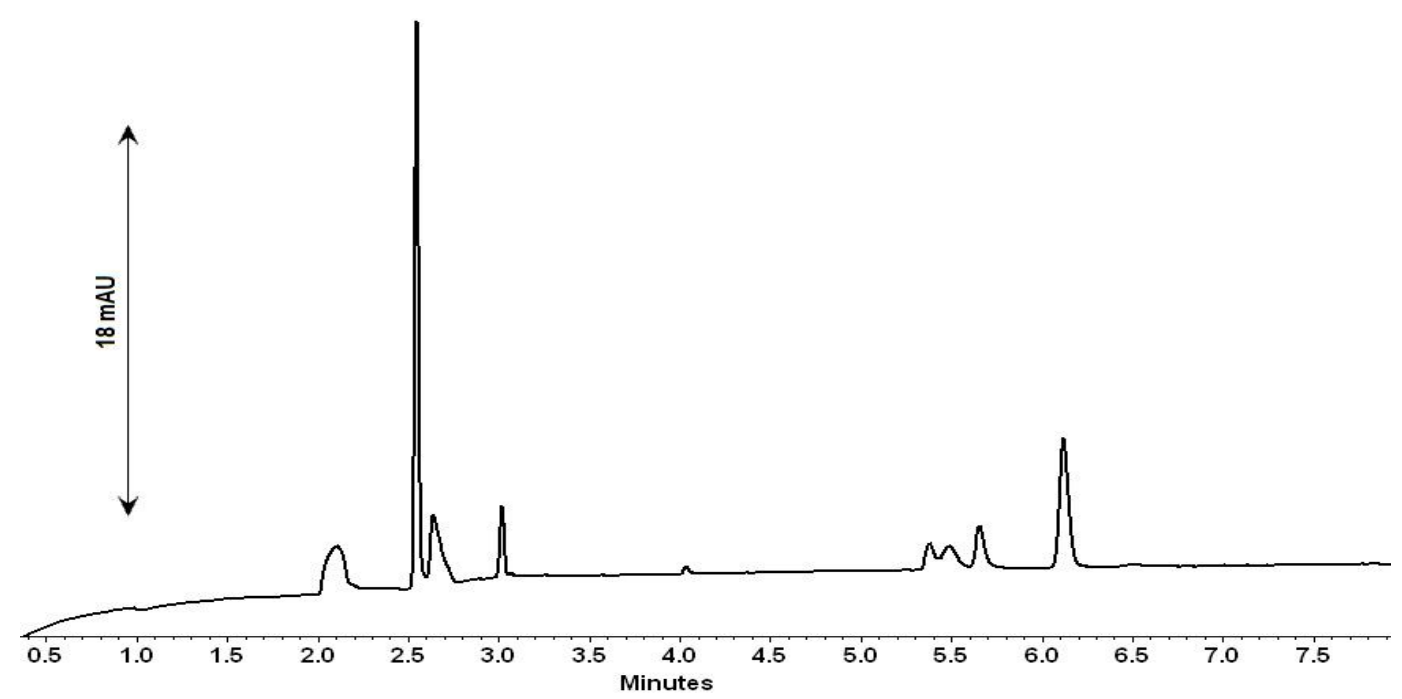

Figura 21. Eletroferograma da solução de gemifloxacino $50,0 \mu \mathrm{g} \mathrm{mL} \mathrm{m}^{-1}$ após $2 \mathrm{~h}$ de hidrólise em meio oxidativo. Condições: capilar de sílica fundida com 40,2 cm (30 cm efetivo) $\times 75 \mu \mathrm{m}$ (d.i.) $\times 375 \mu \mathrm{m}$ (d.e.); eletrólito: tampão tetraborato de sódio 50 mmol $\mathrm{L}^{-1}(\mathrm{pH} 8,6)$; voltagem de $+18 \mathrm{kV}$; temperatura de $18^{\circ} \mathrm{C}$; introdução hidrodinâmica da amostra por 5 s a 0,5 psi e absorção UV em 263 nm.

\subsection{Hidrólise em meio ácido}

$\mathrm{Na}$ hidrólise em meio ácido com $\mathrm{HCl} 0.1 \mathrm{mmol} \mathrm{L}^{-1}$, apresentada na Figura 22, apareceram, no mesmo tempo de retenção do gemifloxacino, picos desconhecidos com respostas instrumentais de baixa detecção. 


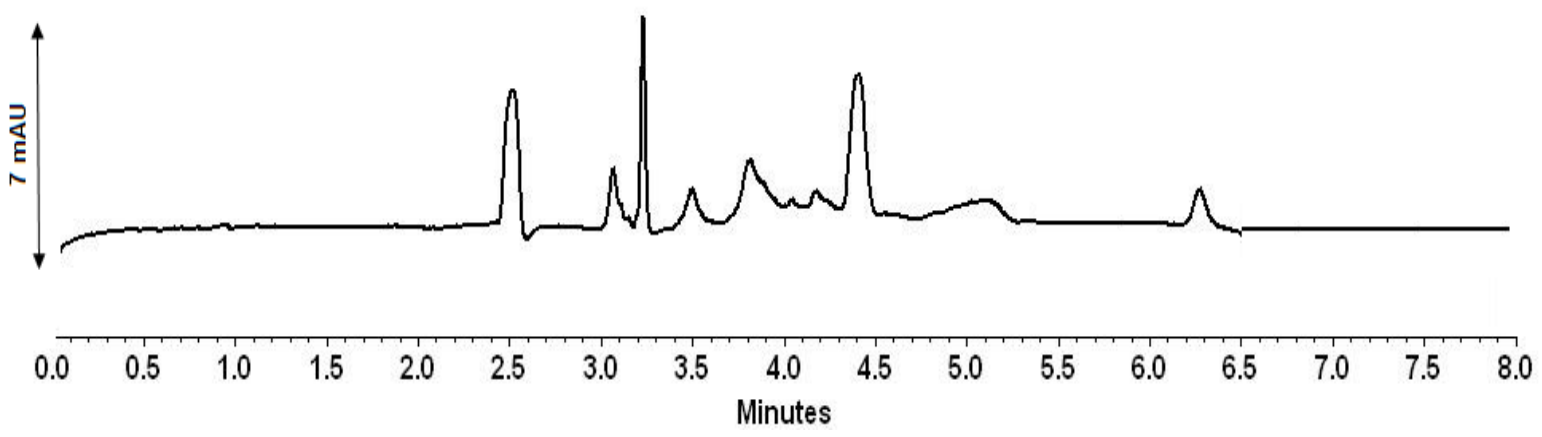

Figura 22. Eletroferograma da solução de gemifloxacino $50,0 \mu \mathrm{g} \mathrm{mL}^{-1}$ após $2 \mathrm{~h}$ de hidrólise em meio ácido. Condições: capilar de sílica fundida com 40,2 cm (30 cm efetivo) $\times 75 \mu \mathrm{m}$ (d.i.) $\times 375 \mu \mathrm{m}$ (d.e.); eletrólito: tampão tetraborato de sódio 50 mmol L $\mathrm{L}^{-1}(\mathrm{pH} 8,6)$; voltagem de $+18 \mathrm{kV}$; temperatura de $18^{\circ} \mathrm{C}$; introdução hidrodinâmica da amostra por $5 \mathrm{~s}$ a 0,5 psi e absorção UV em 263 nm.

\subsection{Hidrólise em meio básico}

A Figura 23 apresenta o eletroferograma com picos desconhecidos com baixa detecção em relação ao gemifloxacino.

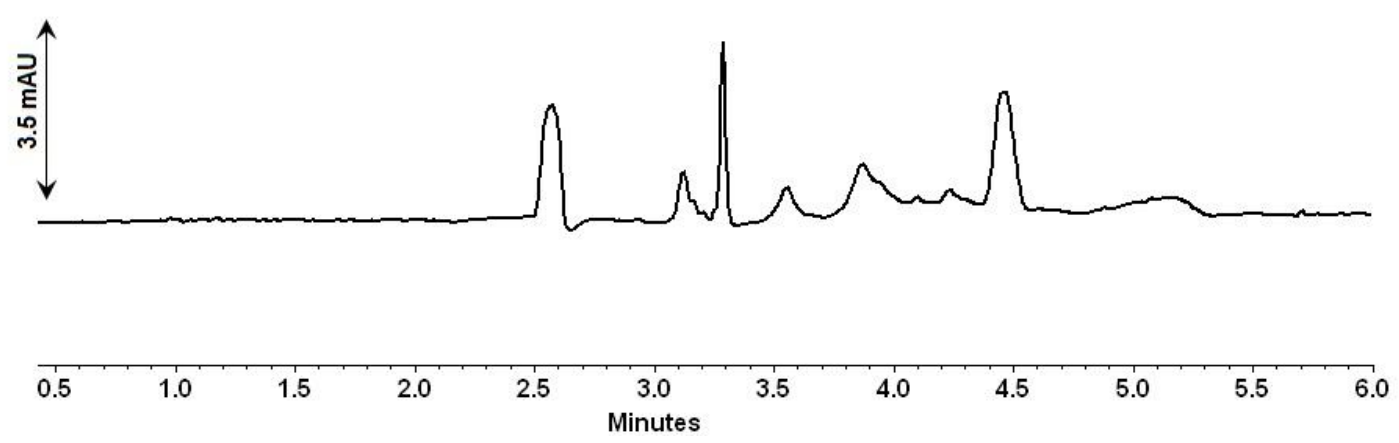

Figura 23. Eletroferograma da solução de gemifloxacino $50,0 \mu \mathrm{g} \mathrm{mL}^{-1}$ após $2 \mathrm{~h}$ de hidrólise em meio básico. Condições: capilar de sílica fundida com 40,2 cm (30 cm efetivo) $\times 75 \mu \mathrm{m}$ (d.i.) $\times 375 \mu \mathrm{m}$ (d.e.); eletrólito: tampão tetraborato de sódio 50 mmol L $\mathrm{L}^{-1}(\mathrm{pH} 8,6)$; voltagem de $+18 \mathrm{kV}$; temperatura de $18^{\circ} \mathrm{C}$; introdução hidrodinâmica da amostra por $5 \mathrm{~s}$ a 0,5 psi e absorção UV em $263 \mathrm{~nm}$.

\subsection{Linearidade}

Para definir a relação entre a resposta do instrumento e a concentração conhecida do analito foi gerada uma curva analítica com sete soluções padrão no intervalo de concentração entre 35,0 e $65,0 \mu \mathrm{g} \mathrm{m}^{-1}$, adicionadas de PI. A 
sobreposição dos picos está apresentada na Figura 24. A representação gráfica da curva analítica e equação da reta estão ilustradas na Figura 25 e os dados estatísticos estão indicados na Tabela 15. Foi assim comprovada a boa linearidade do método ( $r$ de 0.9992).

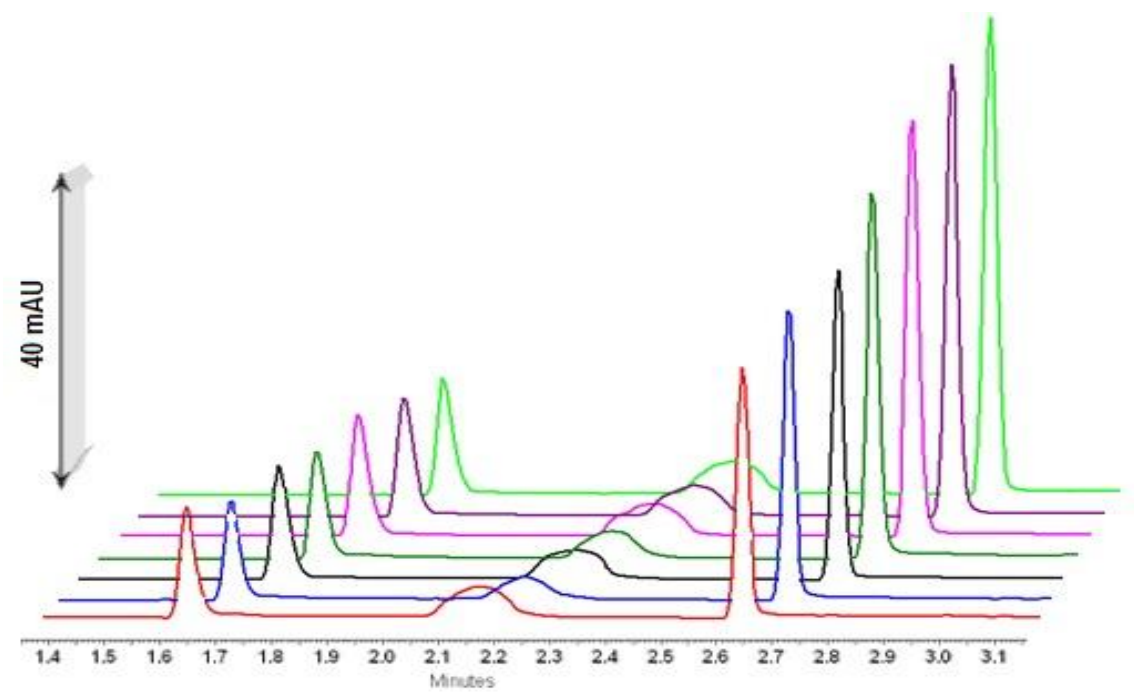

Figura 24. Sobreposição dos eletroferogramas da curva analítica nas concentrações de 35,0 a 65,0 $\mu \mathrm{g} \mathrm{mL}^{-1}$, com adição de PI. Condições: capilar de sílica fundida com 40,2 cm (30 cm efetivo) x $75 \mu \mathrm{m}$ (d.i.) × $375 \mu \mathrm{m}$ (d.e.); eletrólito: tampão tetraborato de sódio $50 \mathrm{mmol} \mathrm{L}^{-1}(\mathrm{pH} 8,6)$; voltagem de $+18 \mathrm{kV}$; temperatura de $18^{\circ} \mathrm{C}$; introdução hidrodinâmica da amostra por 5 s a 0,5 psi e absorção UV em 263 nm.

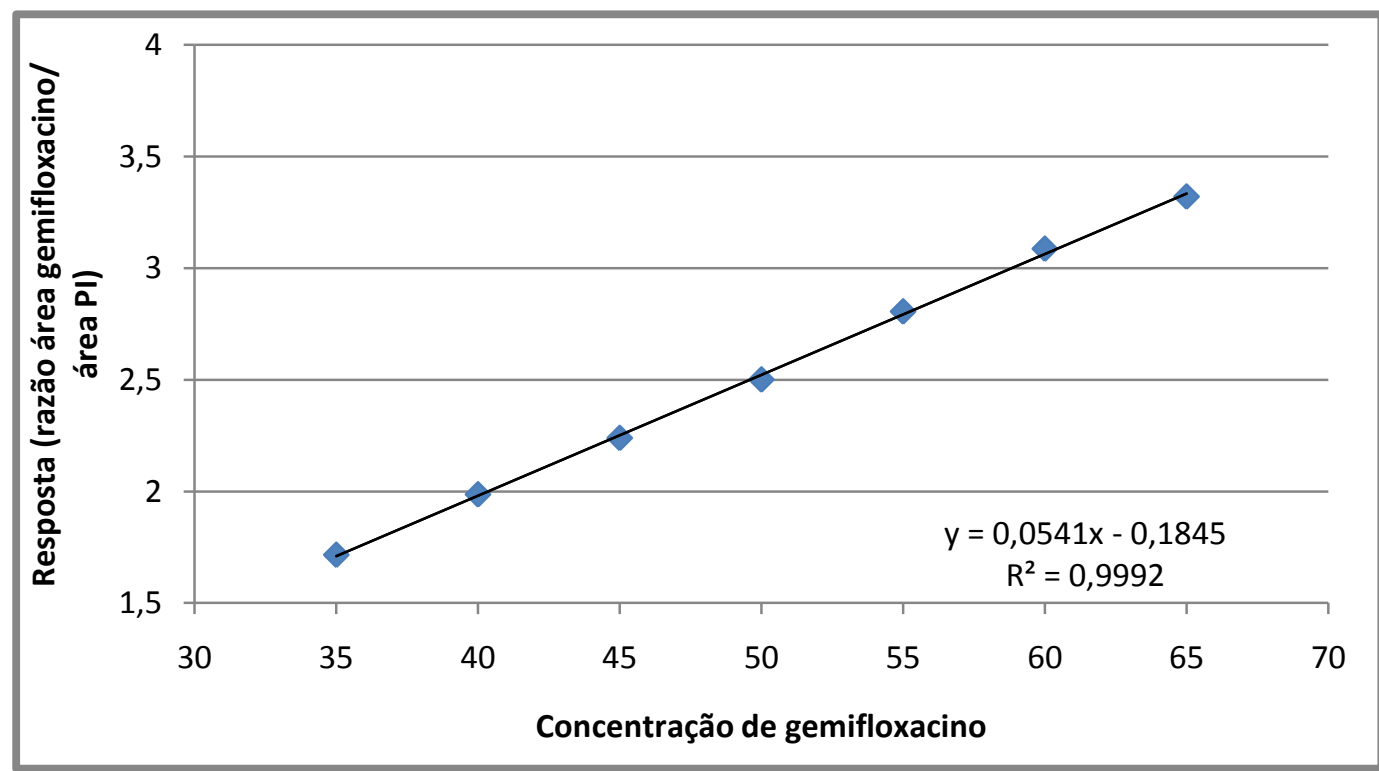

Figura 25. Curva de calibração do gemifloxacino na faixa de concentrações de 35,0 a $65,0 \mu \mathrm{g} \mathrm{m}^{-1}$. Padrão interno. metoprolol $\left(500,0 \mu \mathrm{g} \mathrm{mL}^{-1}\right)$. 
Tabela 15. Resultados experimentais obtidos na determinação da curva analítica do gemifloxacino. Método: CZE

\begin{tabular}{lc}
\hline $\begin{array}{c}\text { Concentração de leitura } \\
\left(\mu \mathrm{g} \mathrm{mL}^{-1}\right)\end{array}$ & $\begin{array}{c}\text { Resposta* }^{*} \\
(\mathbf{A} / \mathbf{A})^{* \star}\end{array}$ \\
\hline 35,0 & 1,7163 \\
40,0 & 1,9871 \\
45,0 & 2,2397 \\
50,0 & 2,5015 \\
55,0 & 2,8063 \\
60,0 & 3,0871 \\
\hline 65,0 & 3,3208 \\
\hline Inclinação (b) & 0,0541 \\
Desvio padrão da inclinação $\left(\mathrm{S}_{\mathrm{b}}\right)$ & $6,68 \mathrm{e}-4$ \\
Intercepto (a) & $-0,1845$ \\
Desvio padrão do intercepto $\left(\mathrm{S}_{\mathrm{a}}\right)$ & 0,03406 \\
Erro padrão da estimativa $($ Se $)$ & 0,01767 \\
Coeficiente de correlação $(\mathrm{r})$ & 0,9992 \\
\hline * Média de três leituras. & \\
** Razão das áreas dos picos $(\mathrm{gemifloxacino} \mathrm{/} \mathrm{metoprolol)}$
\end{tabular}

\subsection{Limite de detecção e limite de quantificação}

A avaliação do $L Q$ e do $L D$ é de extrema importância para o controle de qualidade, visando o uso futuro do método. Foi determinado o menor valor que o analito pode ser detectado e o menor valor quantificável com precisão e exatidão. Como esperado, os valores encontrados para o método eletroforético, apresentados na Tabela 16, foram maiores do que os encontrados para o método cromatográfico.

Tabela 16. Resultados obtidos na determinação dos limites de detecção e quantificação do gemifloxacino. Método: CZE

\begin{tabular}{cc}
\hline Parâmetro & Gemifloxacino $\left(\mu \mathbf{g ~ m L}^{-1}\right)$ \\
\hline Limite de deteção & 3,15 \\
Limite de quantificação & 9,55 \\
\hline
\end{tabular}




\subsection{Precisão}

O método desenvolvido por EC apresentou-se preciso (Tabela 17). Esses valores foram calculados com base na razão das áreas dos picos de gemifloxacino e do PI. Na precisão intermediária não foi verificada nenhuma mudança significativa no sinal, indicando estabilidade instrumental e boa estabilidade das soluções (Tabela 18).

Tabela 17. Resultados obtidos na determinação da repetibilidade da precisão. Método: CZE

\begin{tabular}{c|c}
\hline $\begin{array}{c}\text { Concentração padrão } \\
\left(\mu \mathrm{g} \mathrm{mL}^{-1}\right)\end{array}$ & $\begin{array}{c}\text { Resposta } \\
(\mathbf{A} / \mathbf{A})^{\star}\end{array}$ \\
\hline 50,0 & 1,24036 \\
50,0 & 1,20612 \\
50,0 & 1,22461 \\
50,0 & 1,20691 \\
50,0 & 1,20688 \\
50,0 & 1,21600 \\
50,0 & 1,20268 \\
50,0 & 1,20697 \\
50,0 & 1,19753 \\
50,0 & 1,22462 \\
\hline Média & $\mathbf{1 , 2 1 3 2 7}$ \\
Desvio padrão & $\mathbf{0 , 0 1 3 0 4}$ \\
Desvio padrão relativo & $\mathbf{1 , 0 7 4 7 8}$ \\
\hline
\end{tabular}

* Razão das áreas dos picos (gemifloxacino / metoprolol)

Tabela 18. Resultados obtidos na determinação na precisão intermediária em três dias consecutivos. Método: CZE

\begin{tabular}{|c|c|c|c|c|}
\hline INTER-DIA & $\begin{array}{l}\text { Parâmetros } \\
\text { estatísticos* }\end{array}$ & $40,0 \mu \mathrm{g} / \mathrm{mL}$ & $50,0 \mu \mathrm{g} / \mathrm{mL}$ & $60,0 \mu \mathrm{g} / \mathrm{mL}$ \\
\hline \multirow{2}{*}{ Dia 01} & Média** & 1,00 & 1,21 & 1,49 \\
\hline & DPR (\%) & 2,12 & 3,51 & 1,74 \\
\hline \multirow{2}{*}{ Dia 02} & Média** & 1,64 & 2,49 & 2,99 \\
\hline & DPR (\%) & 2,20 & 2,80 & 2,31 \\
\hline \multirow{2}{*}{ Dia 03} & Média** & 1,97 & 2,15 & 2,82 \\
\hline & DPR (\%) & 4,34 & 4,34 & 3,98 \\
\hline
\end{tabular}

* Média de dez determinações

** Razão das áreas dos picos (gemifloxacino / metoprolol) 


\subsection{Exatidão}

A Tabela 19 apresenta os resultados obtidos na análise da exatidão através do teste de recuperação. Para as três diferentes concentrações de padrão adicionadas a amostra, foi obtida a recuperação com resultados aceitáveis por estarem próximos ao valor real. O método pode ser considerado como exato. Foi observado que os DPR encontrados não ultrapassam $2.00 \%$, indicando baixa variabilidade instrumental.

Tabela 19. Resultados obtidos no teste de recuperação do gemifloxacino. Método: CZE

\begin{tabular}{ccccc}
\hline $\begin{array}{c}\text { Resposta } \\
\text { Padrão }\end{array}$ & $\begin{array}{c}\text { Padrão adicionado } \\
\left(\mu \mathrm{g} \mathrm{mL}^{-1}\right)\end{array}$ & $\begin{array}{c}\text { Resposta* }^{*} \\
(\mathbf{A} / \mathbf{A})^{\star \star}\end{array}$ & $\begin{array}{c}\text { Recuperação } \\
(\%)\end{array}$ & $\begin{array}{c}\text { Média da } \\
\text { recuperação } \\
\text { I DPR }\end{array}$ \\
\hline \multirow{2}{*}{2,39525} & 5,0 & 2,83113 & 99,6 & \\
& 10,0 & 3,12852 & 101,8 & $101,1 \pm 1,3$ \\
\hline
\end{tabular}

${ }^{*}$ Média de quatro leituras,

** Razão das áreas dos picos (gemifloxacino / metoprolol)

\subsection{Comparação estatística dos métodos}

A Tabela 20 apresenta a comparação estatística dos resultados obtidos pelos dois métodos validados. Foi observada pequena variação na linearidade de ambas as metodologias. O método desenvolvido por CLAE se mostrou mais sensível do que o método por CZE.

Tabela 20. Comparação das metodologias desenvolvidas

$\begin{array}{lll}\text { Parâmetros estatísticos CLAE } & \text { CZE }\end{array}$

\begin{tabular}{lcc}
\hline Faixa de concentração $\left(\mu \mathrm{g} \mathrm{mL}^{-1}\right)$ & $35,0-65,0$ & $35,0-65,0$ \\
Equação da reta & $y=124472 x-402720$ & $y=0,0541 x-0,1845$ \\
Coeficiente de correlação $(r)$ & 0,9989 & 0,9992 \\
LQ $\left(\mu \mathrm{g} \mathrm{mL}^{-1}\right)$ & 0,33 & 3,15 \\
$\mathrm{LD}\left(\mu \mathrm{gL}^{-1}\right)$ & 0,99 & 9,55 \\
\hline
\end{tabular}


Para a comparação estatística, compilou-se os dados apresentados na Tabelas 12, 13 (CLAE), 17 e 18 (CZE) através de um software estátistico. Os valores encontrados nos cálculos de significância mostraram que diferenças entre ambas as metodologias desenvolvidas e validadas, não são significativas em relação à precisão (desvio padrão). Os valores encontrados foram 0.00 para o teste $t$ e 1,00 para o teste $F$, ambos abaixo do valor tabelado (2.26 e 3,14, respectivamente) para um nível de significância de 95\%. 


\section{CONCLUSÕES}

Visando a aplicação em análise de rotina de laboratórios de Controle Físico Químico de Qualidade, os métodos propostos para a determinação quantitativa de gemifloxacino exclusivamente em comprimidos, proporcionaram simplicidade na preparação e resultados confiáveis.

O método proposto em CLAE se diferencia das poucas metodologias existentes pela simplicidade em relação a fase móvel e tempo de retenção. Por sua vez a CZE se destaca pela simplicidade do eletrólito de corrida, sem a necessidade de solução tampão muito elaboradas, obtendo-se assim resultados precisos e exatos. Além disso, ambas metodologias utilizaram de água purificada para o preparo da amostra, sendo assim mais barata.

As avaliações dos resultados das validações demonstraram a eficiência das metodologias desenvolvidas, por estarem dentro dos critérios de aceitação determinados pela legislação vigente.

Os métodos se mostraram lineares e sensíveis. Não houve interferência dos excipientes nos métodos, que podem, portanto serem considerados seletivos nos tempos de retenção e migração (CLAE e CZE, respectivamente). O teste de estresse indicou que ambos podem ser utilizados como métodos indicativos de estabilidade, visto que são capazes de detectar vários produtos provenientes das diferentes condições de estresse físico e químico.

As análises dos comprimidos revestidos de gemifloxacino disponíveis comercialmente mostraram que ambos os métodos possuem recuperação/ exatidão de aproximadamente $100.0 \%$. Os métodos propostos em cada técnica analítica são estatisticamente equivalentes quanto à precisão, com um nível de confiança de $95.0 \%$

A técnica cromatográfica é considerada clássica e a técnica eletroforética é relativamente nova e ainda de baixa utilização no setor farmacêutico, contudo, ambas as técnicas desenvolvidas se mostraram eficientes para a análise de fármacos estruturalmente complexos, como o gemifloxacino. Por diferenças instrumentais, a CLAE mostrou ser uma técnica com maior sensibilidade do que a 
CZE. Este fato era esperado, e foi demonstrado pelos resultados obtidos para os valores de LD e LQ. Por outro lado, o método eletroforético consome menor quantidade de reagentes, solventes e soluções, tornando a técnica ecologicamente correta e economicamente viável em longo prazo. 


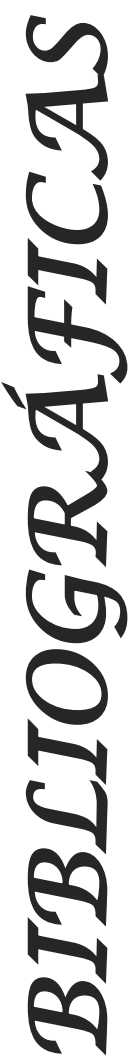

3

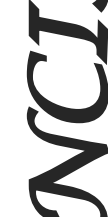

से

$(4)$

4

सि 


\section{REFERÊNCIAS BIBLIOGRÁFICAS}

ALTRIA, K.D., ed. Capillary electrophoresis guidebook: principles, operation, and applications. Totowa: Humana Press, 1996. 349p. (Methods in Molecular Biology, v.52).

ALTRIA, K.D.; CHANTER, Y.L. Validation of capillary electrophoresis method for the determination of a quinolone antibiotic and its related impurities. Journal of Chromatography, A, v.652, p.459-463, 1993

ANDREU, V.; BLASCO, C.; PICÓ, Y. Analytical strategies to determine quinolone residues in food and the environment. TrAC, Trends in Analytical Chemistry, v.26, n.6, p.534-556, 2007.

ANSEL, H.; PRINCE, S. Manual de cálculos farmacêuticos. Porto Alegre: Artmed, 2005. 300p.

APPELBAUM, P.C.; HUNTER, P.A. The fluorquinolone antibacterials: past, present and future perspectives. International Journal of Antimicrobial Agents, v.16, p.5$15,2000$.

ARAUJO, P. Key aspects of analytical method validation and linearity evaluation. Journal of Chromatography, B: Analytical Technologies in the Biomedical and Life Sciences, v.877, n.23, p.2224-2234, 2009.

AWADALLAH, B.; SCHIMIDT, P.C.; WAHL, M.A. Quantitation of the enantiômeros of ofloxacino by capillary electrophoresis in parts per billion concentration range for in vitro drug absorption studies. Journal of Chromatography, A, v.988, p.135-143, 2003.

BALL, P.; FILE, T.M.; TWYNHOLM, M.; HENKEL, T. Efficacy and safety of gemifloxacino $320 \mathrm{mg}$ once-daily for 7 days in the treatment of adult lower respiratory tract infections. International Journal of Antimicrobial Agents, v.18, p.19-27, 2001. 
BALL, P.; MANDELL, L.; PATOU, G.; DANKNER, W.; TILLOTSON, G. A new respiratory fluorquinolone, oral gemifloxacino: a safety profile in context. International Journal of Antimicrobial Agents, v.23, p.421-429, 2004.

BARBOSA, J.; BARRÓN, D.; JIMÉNEZ-LOZANO, E. Electrophoretic behavior of quinolonas in capillary electrophoresis: effect of $\mathrm{pH}$ and evaluation of ionization constants. Journal of Chromatography, A, v.839, p.183-192, 1998.

BARRÓN, D.; JIMÉNEZ-LOZANO, E.; BARBOSA, J. Prediction of electrophoretic behaviour of a series of quinolones in aqueous methanol. Journal of Chromatography, A, v.919, p.395-406, 2001.

BELTRÁN, J.L.; JIMÉNEZ-LOZANO, E.; BARRÓN, D.; BARBOSA, J. Determination of quinolone antimicrobial agents in strongly overlapped peaks from capillary electrophoresis using multivariate calibration methods. Analytica Chimica Acta, v.501, p.137-141, 2003.

BRASIL. Agência Nacional de Vigilância Sanitária. Leislação. VisaLegis. Resolução RDC n.17, de 16 de abril de 2010. A Agência Nacional de Vigilância Sanitária (ANVISA) determina a todos os estabelecimentos fabricantes de medicamentos, 0 cumprimento das diretrizes estabelecidas no Regulamento Técnico das Boas Práticas para a Fabricação de Medicamentos, conforme ao Anexo I da presente Resolução. Disponível em: http://www.anvisa.gov.br/legis. Acesso em: 01 jul. 2010.

CHAKRABARTY, U.S.; DAS, A.; BHAUMIK, U.; CHATTERJEE, B.; GHOSH, A.; BOSE, A.; SENGUPTA, P.; NANDI, U.; PAL, T.K. Rapid and sensitive LC method for the analysis of Gemifloxacin in human plasma. Chromatographia, v.69, p.853-858, 2009.

CINQUINA, A.L.; ROBERTI, P.; GIANNETTI, L.; LONGO, F.; DRAISCI, R.; FAGIOLO, A.; BRIZIOLI, N.R. Determination of enrofloxacin and its metabolite ciprofloxacin in goat milk by high-performance liquid chromatography with diodearray detection: optimization and validation. Journal of Chromatography, A, v.987, p.221-226, 2003.

COLLINS, C.H.; BRAGA, G.U.L.; BONATO, P.S., orgs. Fundamentos de cromatografia. Campinas: UNICAMP, 2006. 453p. 
CROSS Jr., J.T.; CAMPBELL Jr., G.D. Drug-resistant pathogens in community- and hospital-acquired pneumonia. Clinics in Chest Medicine, v.20, n.3, p.499-506, 1999.

CRUZ, L.A.; HALL, R. Enantiomeric purity assay of moxifloxacino hydrochloride by capillary electrophoresis. Journal of Pharmaceutical and Biomedical Analysis, v.38, p.8-13, 2005.

DEWÉ, W. Review of statistical methodologies used to compare (bio)assays. Journal of Chromatography, B: Analytical Technologies in the Biomedical and Life Sciences, v.877, n.23, p.2208-2213, 2009.

DOYLE, E.; FOWLES, S.E.; McDONNELL, D.F.; McCARTHY, R.; WHITE, S.A. Rapid determination of gemifloxacin in human plasma by high-performance liquid chromatography-tandem mass spectrometry. Journal of Chromatography, B: Biomedical Sciences and Applications, v.746, n.2, p.191-198, 2000.

DRUGBANK database. Drug card for Gemifloxacin (DB01155). Disponível em: http://www.drugbank.ca/drugs/DB01155. Acesso em: 04 fev. 2009.

ELBASHIR, A.A.; SAAD, B.; ALI, A.S.M. Validated stability indicating assay of gemifloxacin and lomefloxacin in tablet formulations by capillary electrophoresis. Talanta, v.77, p.1388-1393, 2009.

ERNI, F. Use of high-performance liquid chromatography in the pharmaceutical industry. Journal of Chromatography, v.507, p.141-149, 1990.

FARIA, A.; SOUZA, M.V.N.; ALMEIDA, M.V.; OLIVEIRA, M.A.L. Simultaneous separation of five fluorquinolone antibiotics by capillary electrophoresis. Analytica Chimica Acta, v.579, p.185-192, 2006.

FIERENS, C.; HILLAERT, S.; VAN DEN BOSSCHE, W. The qualitative and quantitative determination of quinolones of first and second generation by capillary electrophoresis. Journal of Pharmaceutical and Biomedical Analysis, v.22, p.763$772,2000$. 
HASEMANN, P.; BALK, M.; WATZIG, H. Analysis of substances to be used as internal standards in MEKC. Chromatographia, v.28, p.1798-1804, 2007.

REMINGTON: a ciência e a prática da farmácia. 20.ed. Rio de Janeiro: Guanabara Koogan, 2004. 2228p.

GIL, E.S., org. Controle físico-químico de qualidade de medicamentos. 2.ed. São Paulo: Pharmabooks, 2007. 485p.

GOODMAN, L.S.; GILMAN, A.; BRUNTON, L.L.; LAZO, J.S.; PARKER, K.L., eds. Goodman \& Gilman As bases farmacológicas da terapêutica. 11.ed. Rio de Janeiro: McGraw-Hill, 2007. 1821p.

GRELLET, J.; BA, B.; SAUX, M.C. High-performance liquid chromatographic separation of fluorquinolone enantiomers: a review. Journal of Biochemical and Biophysical Methods, v.54, p.221-233, 2002.

HERNÁNDEZ, M.; BORRUL, F.; CALULL, M. Analysis of antibiotics in biological samples by capillary electrophoresis. TrAC, Trends in Analytical Chemistry, v.22, p.416-426, 2003.

HARRIS, D.C. Análise química quantitativa. 6.ed. Rio de Janeiro: Livros Técnicos e Científicos, 2005. 876p.

HOOPER, D.C. Clinical applications of quinolones. Biochimica et Biophysica Acta, v.1400, p.45-61, 1998.

INTERNATIONAL CONFERENCE ON HARMONIZATION OF TECHNICAL REQUIREMENTS FOR REGISTRATION OF PHARMACEUTICALS FOR HUMAN USE. ICH Harmonised Tripartite Guideline. Validation of Analytical Procedures: Text and Methodology Q2(R1). 2005. Disponível em: http://www.bioforum.org.il/Uploads/Editor/karen/q2_r1_step4.pdf. Acesso em: 15 mar 2010

JIMÉNEZ-LOZANO, E.; MARQUÉS, I.; BARRÓN, D.; BELTRÁN, J.L.; BARBOSA, J. Determination of $\mathrm{pKa}$ values of quinolones from mobility and spectroscopic data 
obtained by capillary electrophoresis and diode array detector. Analytica Chimica Acta, v.464, p.37-45, 2002.

KOROLKOVAS, A.; FRANÇA, F. Dicionário terapêutico Guanabara 2004/2005. 11.ed. Rio de Janeiro: Guanabara Koogan, 2004. 1v.

KASSAB, N.M.; SINGH, A.K.; KEDOR-HACKMAM, E.R.M.; SANTORO, M.I.R.M. Quantitative determination of ciprofloxacin and norfloxacin in pharmaceutical preparations by high performance liquid chromatography. Revista Brasileira de Ciências Farmacêuticas, v.41, p.507-513, 2005.

KUHN, R.; HOFFSTETTER-KHUN, S. Capillary electrophoresis: principles and practice. Berlin: Springer Laboratory, 1993. 375p. (Springer Laboratory).

LEITE, F. Validação em análise química: conceitos, repê, reprô, estatística, calibrações. 4.ed. Campinas: Átomo, 2002. 278p.

LIN, C.-E.; DENG , Y.J.; LIAO, W.-S.; SUN, S.-W.; LIN, W.-Y.; CHEN, C.-C. Electrophoretic behaviour and pKa determination of quinolones with a piperazinyl substituent by capillary zone electrophoresis. Journal of Chromatography, A, v.1051, n.1/2, p.283-290, 2004.

LIU, Y.M.; CAO, J.T.; WANG, H. Capillary electrophoresis with electrochemiluminescence detection for the analysis of quinolone drugs and pharmacokinetics study. Chinese Chemical Letters, v.19, p.962-964, 2008.

MAMANI, M.C.V.; AMAYA-FARFAN, J.; REYES, F.G.R.; SILVA, J.A.F.; RATH, S. Use of experimental design and effective mobility calculations to develop a method for the determination of antimicrobials by capillary electrophoresis. Talanta, v.76, p.1006-1014, 2008.

MERCK Index: an encyclopedia of chemicals, drugs and biologicals. 14.ed. Whitehouse Station: Merck, 2006.

MICHALSKA, K.; PAJCHEL, G.; TYSKI, S. Determination of ciprofloxacin and its impurities by capillary zone electrophoresis. Journal of Chromatography, A, v.1051, p.267-272, 2004. 
MILLER, J.C.; MILLER, J.N. Estadística para química analítica. 2.ed. Delaware: Addison-Wesley Iberoamericana, 1993. 211p.

MOLLER, J.-G.; STASS, H.; HEINIG, R.; BLASCHKE, G. Capillary electrophoresis with laser - induced fluorescence: a routine method to determine moxifloxacin in human body fluids in very small samples volumes. Journal of Chromatography, B: Biomedical Sciences and Applications, v.716, n.1/2, p.325-334, 1998.

BARROS NETO, B.; SCARMINIO, I.S.; BRUNS, R.E. Como fazer experimentos: pesquisa e desenvolvimento na ciência e na indústria. 3.ed. Campinas: UNICAMP, 2007. 480p.

NGUYEN, H.A.; GRELLET, J.; BA, B.B.; QUENTIN, C.; SAUX, M.-C. Simultaneous determination of levofloxacino, gatifloxacin and moxifloxacin in serum by liquid chromatography with column switching. Journal of Chromatography, B: Analytical Technologies in the Biomedical and Life Sciences, v.810, n.1, p.77-83, 2004.

O'DONNELL, J.A.; GELONE, S.P. The newer fluorquinolones. Infectious Disease Clinics of North America, v.18, p.691-716, 2004.

RANJANE, P.N.; GANDHI, S.V.; KADUKAR, S.S.; BOTHARA, K.G. Stability indicating RP-LC method for the determination of gemifloxacino mesylate. Chromatographia, v.71, p. 1113-1117, 2010.

RANGE, H.P.; DALE, M.M.; RITTER, J.M. Farmacologia. 5.ed. Rio de Janeiro: Elsevier, 2004. p. $736-737$.

RIBANI, M.; BOTTOLI, C.B.G.; COLLINS, C.H.; JARDIM, I.C.S.F.; MELO, L.F.C. Validação em métodos cromatográficos e eletroforéticos. Química Nova, v.27, p.771-780, 2004.

ROTE, A.R.; PINGLE, S.P. Reverse phase-HPLC and HPTLC methods for determination of Gemifloxacin mesylate in human plasma. Journal of Chromatography, B: Analytical Technologies in the Biomedical and Life Sciences, v.877, n.29, p.3719-3723, 2009. 
SANTORO, M.I.R.M.S. Introdução ao controle de qualidade de medicamentos. São Paulo: Atheneu, 1988. 121p.

SANTORO, M.I.R.M.; KASSAB, N.M.; SINGH, A.K.; KEDOR-HACKMANN, E.R.M. Quantitative determination of gatifloxacin, leofloxacin, lomefloxacin and pefloxacin fuorquinolonic antibiotics in pharmaceutical preparations by high - performance liquid chromatography. Journal of Pharmaceutical and Biomedical Analysis, v.40, p.179-184, 2006.

SANTORO, M.I.R.M.; PRADO, M.S.A.; STEPPE, M.; KEDOR-HACKMANN, É.R.M. Eletroforese capilar: teoria e aplicações na análise de medicamentos. Revista Brasileira de Ciências Farmacêuticas, v.36, p.98-110, 2000.

SCHMITT-KOPPLIN, P.H.; BURHENNE, J.; FREITAG, D.; SPITELLER, M.; KETTRUP, A. Development of capillary electrophoresis methods for the analysis of fluorquinolones and application to the study of the influence of humic substances on their photodegradation in aqueous phase. Journal of Chromatography, A, v.837, p.253-265, 1998.

SHABIR, G.A. Validation of high-performance liquid chromatography methods for pharmaceutical analysis. Understanding the differences and similarities between validation requirements of the US Food and Drug Administration, the US Pharmacopeia and the International Conference on Harmonization. Journal of Chromatography, A, v.987, p.57-66, 2003.

SILVA, P., ed. Farmacologia. 7.ed. Rio de Janeiro: Guanabara Koogan, 2006. $1369 p$.

SNYDER, L.R.; KIRKLAND, J.J.; GLAJCH, J.L. Practical HPLC method development. 2.ed. New York: Wiley Interscience, 1997. 765p.

SUN, H.; HE, P.; LV, Y.; LIANG, S. Effective separation and simultaneous determination of seven fluorquinolones by capillary electrophoresis with diode - array - detector. Journal of Chromatography, A, v.852, p.145-151, 2007.

TAVARES, M.F.M. Eletroforese capilar: conceitos básicos. Química Nova, v.19, p.173-181, 1996. 
TAVARES, M.F.M. Mecanismos de separação em eletroforese capilar. Química Nova, v.20, p.493-511, 1997.

TAVARES, W. Manual de antibióticos e quimioterápicos antiinfecciosos. 3.ed. São Paulo: Atheneu, 2002. 1216p. (alterei a data de 2001 para 2002; alterar no texto)

TAVENIERS, I.; LOOSE, M.; BOCKSTAELE, E.V. Trends in quality in the analytical laboratory. II. Analytical method validation and quality assurance. TrAC, Trends in Analalytical Chemestry, v.23, p.535-551, 2004.

UNITED States Pharmacopeia: USP33. Rockville: United States Pharmacopeial Convention, 2010. v.1, p.773-777.

WANG, Y.; BAEYENS, W.R.G.; HUANG, C.; FEI, G.; OUYANG, J. Enhanced separation of seven quinolones by capillary electrophoresis with sílica nanoparticles as additive. Talanta, v.77, p.1667-1674, 2009.

WATSON, D.G. Pharmaceutical analysis: a textbook for pharmacy students and pharmaceutical chemist. Toronto: Churchill Livingstone, 1999. p.293-300.

ZHANG, Y.; ZHANG, Z.; ZHOU, Y.; LIU, L.; ZHU, Y. Determination of fluorinated quinolone antibacterials by ion chromatography with fluorescence detection. Journal of Zhejiang University, Science, B, v.8, p.302-306, 2007.

ZHOU, S.; OUYANG, J.; BAEYENS, W.R.G.; ZHAO, H.; YANG, Y. Chiral separation of four fluorquinolone compounds using capillary electrophoresis with hydroxypropyl - $\beta$ - cyclodextrin as chiral selector. Journal of Chromatography, A, v.1130, p.296301, 2006.

ZHOU, X.; XING, D.; ZHU, D.; TANG, Y.; JIA, LI. Development and application of a capillary electrophoresis - electrochemiluminescent method for the analysis of enrofloxacin and its metabolite ciprofloxacin in milk. Talanta, v.75, p.1300-1306, 2008. 


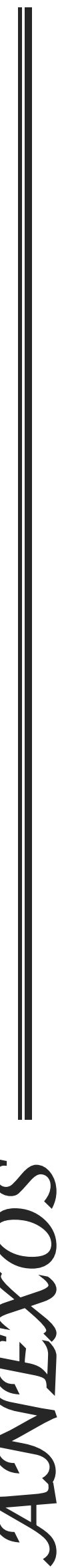

